\author{
UNIVERSIDADE DE SÃO PAULO \\ FACULDADE DE FILOSOFIA, LETRAS E CIÊNCIAS HUMANAS \\ DEPARTAMENTO DE LETRAS MODERNAS \\ PROGRAMA DE PÓS-GRADUAÇÃ O EM ESTUDOS LINGUÍSTICOS E \\ LITERÁRIOS EM INGLÊS
}

\title{
MISTURA FINA, OU A VERDADEIRA HISTÓRIA DAS AVENTURAS DE DAVID SIMPLE
}

Mariana Teixeira Marques

\begin{abstract}
Dissertação apresentada ao Programa de Pós-Graduação em Estudos Lingüísticos e Literários em Inglês, do Departamento de Letras Modernas da Faculdade de Filosofia, Letras e Ciências Humanas da Universidade de São Paulo (USP), como parte dos requisitos para a obtenção do Título de Mestre em Letras.
\end{abstract}

Orientadora: Profa. Dra. Sandra G. T. Vasconcelos

São Paulo, SP

2006 
UNIVERSIDADE DE SÃO PAULO

FACULDADE DE FILOSOFIA, LETRAS E CIÊNCIAS HUMANAS DEPARTAMENTO DE LETRAS MODERNAS

PROGRAMA DE ESTUDOS LINGUÍSTICOS E LITERÁRIOS EM INGLÊS

\section{MISTURA FINA, OU A VERDADEIRA \\ HISTÓRIA DAS AVENTURAS DE DAVID \\ SIMPLE}

Mariana Teixeira Marques 
Para Aury e Sizenando. 


\section{Agradecimentos}

Vem em primeiro lugar na lista - e não podia ser diferente - a Profa. Sandra Vasconcelos, a quem agradeço a amizade, o respeito, o aprendizado constante - cujo valor vai muito além do trabalho acadêmico. Os amigos todos não ficam atrás, os daqui e os que vêm de outras bandas. Segue a devida gratidão a Bel, Rogério e Renata, pela paciência incondicional; a Luciano Laface, pelas conversas filosóficas intermináveis; aos novos amigos da Escola Graduada, especialmente Andrea, Aleixo, Rogério Dezem e Marião, que contribuíram, cada qual do seu jeito - desde dicas de acentuação até um abraço na hora certa -, para que eu conseguisse chegar até o final; também a Peter Klam e Trae Holland - respectivamente, pelas dicas "shakespereanas" e estilísticas; aos amigos d'outre-mer - tanto do Rio quanto da França - que sempre estiveram presentes, ao menos virtualmente. Enfim, torno pública a minha dívida para com Sheila, Sergio, Marcelo, Rodrigo, Paulo Cesar e Luzia, as pessoas que sempre possibilitaram, de uma maneira ou de outra, que eu colocasse meus sonhos em prática. 


\title{
Resumo
}

As Aventuras de David Simple, primeiro romance de Sarah Fielding publicado em 1744, foi redescoberto pela crítica anglo-saxã nos anos 60 através da adoção de perspectivas que buscavam questionar as abordagens canônicas no que se refere ao romance moderno como gênero. Neste trabalho, procuramos compreender a contribuição, dentro da história do romance, dos principais estudos acerca de David Simple, e propor uma análise crítica que, aproximando-se do material narrativo, visa a expor como se formulam, no nível da fatura, algumas das questões fundamentais da vida socioeconômica e literária da Inglaterra neste período.

\begin{abstract}
The Adventures of David Simple, Sarah Fielding's first novel published in 1744, was rediscovered by Anglo Saxon critics in the 1960's who employed new perspectives that aimed at questioning earlier canonical assumptions regarding the modern novel as a genre. The aim of this research is to understand the contributions, to the history of the novel, of the main studies concerning David Simple, and also to propose a critical analysis that, approaching the narrative material, aims at exposing how the novel formulates, in the managing of its structure and themes, some of the fundamental issues in socioeconomic and literary English life in this period.
\end{abstract}

\section{Palavras-chave / keywords}

\author{
Romance - Inglaterra - século XVIII - Sarah Fielding - David Simple \\ Novel - England - 18th century - Sarah Fielding - David Simple
}




\section{ÍNDICE}

Introdução: Que narra as Histórias de David Simple e Sarah Fielding 7

Capítulo 1: No qual são relatadas as Primeiras Impressões acerca de nosso Romance 23

Capítulo 2: Contendo um passeio filosófico-sentimental que surpreenderá o Leitor 58

Conclusão: Contendo breves comentários e o fim desta análise 127

Referências bibliográficas 131 
Introdução: Que narra as Histórias de Sarah Fielding e de David Simple 


\section{Sarah Fielding e David Simple}

"A woman knows how to be a mercenary, though she has never been in court or at an assembly."

(John Gay, The Beggar's Opera)

\section{Sarah Fielding}

Londres, década de 1740. A maior cidade inglesa - e européia - não parava de crescer, misturando muita riqueza com intensa violência cotidiana. Para quem tinha tempo e dinheiro para se dedicar a algum tipo de diversão, aquele era o lugar: " $E m$ Londres, tudo é fácil para quem tem dinheiro e não tem medo de gastar", diria Casanova $^{1}$. Mas poucos podiam tirar proveito dos atrativos da metrópole: diferentes relatos ao longo do século XVIII a descrevem como uma cidade de grandes contrastes, em que a opulência e a pobreza mais absoluta se encontravam sem cerimônia ${ }^{2}$.

Neste mesmo início da década de 40, enquanto já chegavam à capital notícias sobre greves de trabalhadores do ramo de tecidos no nordeste do país, Sarah Fielding (1710-1768) se muda de Bath, onde estava vivendo, para Londres, a fim de cuidar da casa

\footnotetext{
${ }^{1}$ [In London, everything is easy to him who has money and is not afraid to spend it] Casanova, Giacomo Girolamo, Chevalier de Seingalt (1725-1798), aventureiro italiano nascido em Veneza e cuja reputação com as mulheres ficou legendária. Citado por PORTER, Roy. English Society in the Eighteenth Century, London: Penguin, 1990. p. 232. As traduções dos autores citados em outros idiomas foram feitas por mim, com exceção dos textos para os quais já existe tradução para o português. Nestes casos, utilizei, quando foi possível, a tradução existente.

2 "squalid and pestiferous, lacking the common amenities; a city of violent contrasts between luxury and elegance and poverty and ugliness. A city, above all, of crime and turbulence and hard living” " [esquálida e pestilenta, em que faltavam as comodidades mais comuns; uma cidade de contrastes violentos entre luxo e elegância e pobreza e feiúra. Acima de tudo, uma cidade de crime, turbulência e vida dura.] PLUMB, J.H., England in the Eighteenth Century, London: Penguin, 1983. p. 14.
} 
de seu irmão Henry Fielding, que havia se tornado viúvo ${ }^{3}$. Consagrado como dramaturgo e produtor teatral - além de exercer a profissão de advogado -, H. Fielding se voltava agora para o romance (Joseph Andrews foi publicado em 1742) e afirmava sua presença bastante atuante no cenário político e cultural da cidade.

A temporada londrina serviu não só para confirmar os laços entre os dois irmãos, mas também possibilitou a Sarah Fielding o contato privilegiado - dentro e fora de casa com personagens centrais da vida da capital. Além do fato de H. Fielding ser um homem bastante gregário - o que forçosamente tornava a casa em que Sarah vivia um ponto de encontro -, a autora pôde desenvolver seu próprio círculo de amigos entre membros da pequena fidalguia ${ }^{4}$ e da aristocracia. Sarah Fielding ganhava assim a reputação de bluestocking ${ }^{5}$ que a acompanharia para o resto de sua vida.

É neste ambiente que a romancista escreve e publica seu primeiro romance, cujo título completo é The Adventures of David Simple: Containing an Account of his Travels thro' the Cities of London and Westminster, in the Search of a Real Friend (1744). As aventuras do protagonista se desenrolam justamente nesta cidade que assusta

\footnotetext{
${ }^{3}$ Neste trecho foram utilizadas informações de BREE, Linda, Sarah Fielding, New York: Twayne Publishers, 1996; SHATTOCK, Joanne, The Oxford Guide to British Women Writers, Oxford: Oxford University Press, 1993; TODD, Janet. Dictionary of British Women Writers, London: Routledge, 1991.

${ }^{4}$ Segundo Roy Porter, a pequena fidalguia (em inglês, gentry) era a classe que estava abaixo dos magnatas da terra na pirâmide social. Tratava-se, portanto, de um grupo composto de proprietários que ainda não precisavam trabalhar em suas terras e viviam de renda. No entanto, o espectro social que o termo abrangia era bastante amplo - e a situação econômica, nem sempre favorável a todos: "They ranged from baronets, who in 1700 might have over $£ 1,500$ a year (by 1800 perhaps $£ 4,000$ ), down to the squire feeling the pinch on as little as $£ 300$. (...) These were, however, times when the economics of consolidated, capitalized agriculture and the nip of the land tax helped big gentlemen to get fatter while speeding the smaller ones, and spendthrifts, towards bankruptcy and even the debtor's gaol. By 1800, £300 would no longer support a squire." [ Estes iam de barões, que, em 1700, provavelmente tinham uma renda em torno de 1500 libras por ano (em 1800 talvez 4000 libras) até o squire em dificuldades com 300 libras de renda. (...) Estes eram, no entanto, tempos em que a economia da agricultura capitalista e os impostos sobre a terra auxiliaram os grandes senhores a aumentar sua renda, enquanto aceleravam, para os pequenos proprietários e para os perdulários, o caminho para a bancarrota e mesmo para a prisão por dívidas.] In: PORTER, Roy. op. cit., pp. 66-67.

${ }^{5}$ Em meados do século XVIII, o termo era utilizado - muitas vezes de modo pejorativo - para designar qualquer grupo de homens e mulheres das classes mais abastadas que se reunissem em 'conversations' nas quais, ao invés de se dedicarem às atividades sociais "comuns" (como jogar cartas ou costurar), discutiam literatura e outros assuntos. Ver, a este respeito, HELLER, Deborah. "Bluestocking Salons and the Public Sphere", in: Eighteenth-Century Life, n. 22, vol. 2, 1998, pp. 59-82. A autora defende a tese segundo a qual os salões bluestocking - especialmente aqueles conduzidos por Lady Montagu e Mrs. Vesey - foram importante marca na emergência da esfera pública como um novo paradigma de contato social que se delineia de modo mais claro a partir do século XVIII.
} 
ao mesmo tempo em que encanta seus habitantes. A busca de David não poderia ter ocorrido em outro lugar, como explica o narrador: "[David] concluded, he could sooner enter into the Characters of Men in the great Metropolis where he lived, than if he went to foreign countries" $"$.

Pode-se imaginar que Sarah Fielding tivesse sido beneficiada, neste início de carreira literária, pela situação de seu irmão e pelas relações que pôde estabelecer em seu meio social. Porém, os poucos dados biográficos a respeito da autora parecem indicar que a relação com H. Fielding foi sempre marcada por percalços. Ainda que o romancista estimulasse a produção literária da irmã - alguns críticos afirmam que ela teve participação em Joseph Andrews (1742), na carta de Leonora, e em Miscellanies (1743), na narrativa de Ana Bolena -, ele não concordava inteiramente com seus interesses intelectuais (especialmente no que se refere aos estudos de cultura clássica) - e existe a suspeita de que não tenha sido muito presente em sua vida no tocante aos problemas cotidianos, sobretudo em relação a possíveis auxílios financeiros.

No que se refere à reprovação do interesse de Sarah F. pelo estudo das línguas e das literaturas clássicas, Henry Fielding não fazia mais do que repetir um padrão de sua época. Sabe-se que o contato com a cultura clássica estava confinado, em meados do século XVIII, ao mundo masculino. As mulheres que se aventuravam neste território arriscavam-se a receber elogios como o de Samuel Johnson a Elizabeth Carter, quando esta foi criticada por traduzir, mesmo com competência, The Works of Epictetus: "[she] could make a pudding as well as translate Epictetus"7.

Contrariando a opinião comum, portanto, Sarah F. trabalhou durante anos numa tradução das Memórias de Sócrates, de autoria de Xenofonte, autor bastante apreciado na Inglaterra daquele período. Apoiada pelo amigo James Harris, Sarah finalmente publicou

\footnotetext{
${ }^{6}$ [David concluiu que poderia ter acesso mais fácil ao caráter dos homens na grande metrópole em que vivia do que se fosse a países estrangeiros.] FIELDING, Sarah. The Adventures of David Simple, London: Oxford University Press, 1973. p. 27. Todas as citações do romance a partir de agora se farão utilizando as iniciais e o número de página. DS significa The Adventures of David Simple, de 1744, e VL corresponde a Volume the Last, continuação do romance publicada em 1753. As traduções são minhas.

${ }^{7}$ [podia fazer um pudim assim como traduzir Epíteto.] BREE, Linda. op. cit., p. 21, citado em MYERS, Sylvia H. The Bluestocking Circle: Women, Friendship, and the Life of the Mind in EighteenthCentury England. Oxford: Clarendon, 1990. p. 158.
} 
Memoirs of Socrates, with the Defence of Socrates Before his Judges em 1762. A tradução teve recepção favorável e obteve comentários elogiosos no Monthly Review sem referências aos talentos culinários da tradutora.

Mas seus problemas financeiros eram crônicos. Num mundo em que o matrimônio era a fonte essencial de subsistência para as mulheres, sobretudo aquelas pertencentes à aristocracia e aos estratos médios da sociedade, nem Sarah F., nem quaisquer de suas três irmãs se casaram - apesar de terem "Parts above the common Run" quando estavam em idade de entrar no "mercado de casamentos". O celibato de Sarah F. e de suas irmãs pode ter ocorrido em função da opinião nada positiva que tinham da instituição matrimonial; o mais provável, porém, é que as filhas do Coronel Fielding não fossem ricas o suficiente para atrair maridos de sua posição social.

Mesmo que elas fossem consideradas parte da pequena fidalguia, sua posição social não compensava a ausência de um dote considerável. O Coronel não tinha especialmente o hábito de se preocupar com dinheiro - desperdiçava o que não possuía e havia perdido uma fortuna com o desastre da South Sea Bubble ${ }^{9}$. Após a morte da mãe de Sarah e Henry Fielding, o pai casou-se com uma viúva católica. A avó das crianças, Lady Gould, utilizou estes argumentos para tirar-lhe a guarda das filhas. Surpreendentemente, Lady Gould ganhou a custódia das meninas após um conturbado processo - Sarah F. tinha então 11 anos de idade. Enquanto H. Fielding consolidava sua formação em Eton, as quatro irmãs passaram a viver no internato de Mrs. Mary Rooke em Salisbury.

\footnotetext{
${ }^{8}$ [Qualidades acima da média.] Arthur Collier, citado por Hester Lynch Salusbury Thrale, Thraliana, ed. Katharine Balderston (1942), in: BREE, Linda. op. cit. p. 5.

${ }^{9}$ As companhias de comércio ultramarino tiveram crescente importância na vida econômica da Inglaterra desde o século XVI. A intensificação do comércio e do número de viagens fez com que estas companhias abrissem seu capital a acionistas, tornando-se "joint-stock companies". No início da década de 1710, após o tratado de Utrecht - quando a Inglaterra obtém o monopólio do comércio de escravos com a América Espanhola -, a Coroa concede à recém-fundada South Seas Company o monopólio do trato com a América. Em troca, a companhia assumiria a dívida pública com juros inferiores aos do Bank of England. A partir daí, o número de investimentos na companhia fez com que o preço da ação chegasse rapidamente a dez vezes mais do que o seu valor inicial. Alguns diretores começaram a vender suas ações, o que provocou grande susto e a queda vertiginosa do preço das quotas. Centenas de acionistas foram arruinados quando a "bolha" da South Seas "estourou" em 1720 - entre eles, o Coronel Fielding. É interessante notar, de passagem, que George Lillo dedica sua peça The London Merchant (1731) a Sir John Eyles, filho de burguês nobilitado e vice-diretor da South Sea Company. Ver SZONDI, Peter. Teoria do Drama Burguês, São Paulo: Cosac Naify, 2004.
} 
Afirma-se que a experiência na escola de Mrs. Rooke serviu de estímulo para que Sarah F. escrevesse, mais tarde, uma espécie de manual de educação "romanceado", voltado especialmente à educação de meninas - The Governess, or Little Female Academy (1749). Junto com A Little Pretty Pocket-Book (publicado por John Newbery em 1744) - "the use of which will infallibly make Tommy a good Boy and Polly a good Girl" ${ }^{\prime 10}$-, The Governess é considerado um dos romances precursores da literatura infantil na Inglaterra. Ali é narrada a história de Mrs. Teachum e de suas nove alunas, às quais a professora ensina uma série de preceitos morais baseados, em grande parte, na amizade e no controle das paixões. O livro tornou-se rapidamente referência na formação de moças durante o século XVIII e mesmo depois.

Além da situação familiar peculiar e da falta de dote, estes tímidos interesses e posicionamentos - o estudo do grego e do latim, a defesa de uma educação mais completa para as mulheres -, ainda que não representassem nenhuma ameaça de fato à dominação masculina, eram um péssimo cartão de visitas para futuros candidatos a marido. Sally, the scholar - como era chamada pelas irmãs - se viu, assim, obrigada a passar a vida na precariedade da dependência.

A falta de dinheiro e a ausência de estabilidade material que o casamento teria evitado foram, ao que tudo parece indicar, os principais motivos que a levaram a publicar seus escritos, como ela mesma insiste em afirmar no prefácio à primeira edição de David Simple: "Perhaps the best excuse that can be made for a Woman's venturing to write at all is that which really produced the Book: Distress in her Circumstances"11. Para conseguir vender seus livros e completar o orçamento, Sarah F. contou com a ajuda de alguns amigos - entre eles, Samuel Richardson.

Henry Fielding já havia abandonado o teatro para se dedicar ao romance, e a rivalidade entre ele e Richardson já estava bem estabelecida quando este último entra na

\footnotetext{
${ }^{10}$ [cuja utilização fará infalivelmente de Tommy um bom menino e de Polly uma boa menina.] Ver BREE, Linda, op. cit., p. 58.

${ }^{11}$ [Talvez a única desculpa que se possa dar a uma mulher que se aventure na escrita é aquela que realmente originou o livro: sérias dificuldades em suas circunstâncias.] FIELDING, Sarah. In: GADEKEN, Sara. "Sarah Fielding and the Salic Law of Wit", in: Studies in English Literature 1500-1900, Vol. 42, number 3, Summer 2002. p. 544.
} 
vida de Sarah F., durante a temporada londrina na década de 40. Leitora de todos os romances de Richardson, ela acabou tornando-se amiga do romancista. Os dois mantiveram a relação mesmo depois de Sarah F. ter deixado Londres. A autora de David Simple fazia parte do círculo de freqüentadores da casa de Richardson em Parson's Green, tendo passado uma temporada hospedada ali, juntamente com Jane Collier, inseparável amiga e companheira intelectual desde Salisbury ${ }^{12}$.

A proximidade com Richardson foi de extrema relevância não só para o trabalho, mas também para a vida de Sarah F. O autor de Pamela auxiliou-a no que se refere à produção literária em si - aconselhando-a através da leitura de manuscritos, de sugestões no tocante à impressão e venda dos romances -, mas também emprestando dinheiro à irmã de Fielding mais de uma vez.

Em 1749, Sarah F. publica Remarks on Clarissa, panfleto em defesa do romance de Richardson que havia sido lançado entre 1747 e $1748^{13}$. O texto é organizado na forma de uma carta anônima para o autor na qual são descritas conversas entre alguns leitores a respeito do romance, bem como cartas trocadas entre estes supostos leitores - talvez numa tentativa de reproduzir a experiência da leitura de Clarissa, assim como os debates que resultaram desta ${ }^{14}$.

Remarks é tido como um dos primeiros comentários críticos acerca da obra de Richardson, e dá provas da admiração de Sarah F. pelo amigo e por sua obra. O texto também coloca em evidência a consciência da romancista no tocante às técnicas narrativas escolhidas por Richardson e suas conseqüências. A correspondência entre os dois durou até um pouco antes da morte do autor de Clarissa, em 1761.

\footnotetext{
12 Jane Collier é autora de The Art of Ingeniously Tormenting (1753), cujo título - bastante convidativo anuncia a subversão irônica dos famosos conduct books da época. Juntas, Sarah Fielding e Jane Collier escreveram The Cry (1754), uma espécie de fábula que mistura diferentes gêneros.

${ }^{13}$ Clarissa, or the History of a Young Lady (1747-1748), romance epistolar de S. Richardson, conta a história de uma jovem de boa família que é assediada pelo aristocrático Lovelace. A família de Clarissa se opõe ao casamento, pois já havia entrado em acordo com um rico pretendente, Solmes - o qual a moça detesta. Lovelace acaba convencendo a moça a fugir para Londres. Clarissa ainda resiste aos arroubos sedutores de Lovelace, até que o vilão acaba drogando a moça para violentá-la. Clarissa se deixa morrer de tristeza e Lovelace morre em seguida, durante um duelo.

${ }^{14}$ Ver BREE, Linda. op. cit., p. 74.
} 
Sarah Fielding passou o fim de sua vida em Bath, "spa" da moda muito freqüentado pela sociedade londrina em meados do século XVIII: em 1749, a cidade teria recebido por volta de "12000" turistas (a maioria aristocratas e pequena fidalguia) ${ }^{15}$. Em meio a toda esta agitação, Sarah F. - que já tinha uma rotina bastante solitária - decide fugir definitivamente da vida pública e refugia-se em seus estudos e escritos.

Dedicou-se, assim, em seus últimos anos, à composição de uma biografia de Cleópatra e Otávia - The Lives of Cleopatra and Octavia (1757) -, e de dois romances, The History of the Countess of Dellwyn (1759) e The History of Ophelia (1760). Nos dois últimos, a sociedade londrina, urbana - as classes altas e os estratos médios aparece retratada com a ironia um tanto pessimista de que a romancista já se mostrara capaz desde seu primeiro romance. Ambos relatam os efeitos da corrupção que a vida social poderia trazer para algumas moças sem malícia; ou ainda, dito de outro modo, "the history of a young lady's entrance into the world" ${ }^{\text {"16. }}$

\footnotetext{
${ }^{15}$ Ver BREE, Linda. op. cit., p. 18-19.

${ }^{16}$ [a história da entrada de uma jovem dama no mundo] Ver BREE, Linda. op. cit., p. 123.
} 


\section{David Simple}

Voltemos a 1744. O romance que inaugura a entrada de Sarah Fielding no mercado literário é The Adventures of David Simple. Nele é narrada a história de David, filho primogênito de um rico comerciante de tecidos e único herdeiro dos negócios da família quando chega a morte do pai. Porém, Daniel, o filho mais novo, falsifica o testamento com a ajuda de um casal de criados e acaba ficando com tudo. David inicialmente se conforma com a notícia, mas depois de quase ser expulso de casa pelo seu novo dono, acaba pedindo auxílio a um tio. Este tio providencia a recuperação dos bens do rapaz, e David toma posse do que era seu por direito.

Seria de se esperar, especialmente num romance desta época, que este enredo que lida com a perda e a recuperação do status do herói - se desenvolvesse através de uma extensa série de peripécias, coincidências e dificuldades que David enfrentaria em suas tentativas de reaver seu dinheiro até atingir, no fim da narrativa, sua posição social inicial.

No entanto, o entrecho é desenvolvido rapidamente nos três primeiros capítulos do romance. A narrativa propriamente dita começa no momento em que David, já dono de seu nariz e de sua herança, começa a se perguntar de que vale sua fortuna se não há com quem compartilhá-la... Deste modo, "he at length took the oddest, most unaccountable Resolution that ever was heard of, viz. To travel through the whole World, rather than not meet with a real Friend" (DS, 27). Logo o mundo inteiro the pareceu grande demais, e Londres parecia oferecer uma boa amostragem da humanidade, pois "he had good Sense to know, that Mankind in their Natures are much the same everywhere; and that if he could go through one great Town, and not meet with a generous Mind, it would be in vain to seek farther" (DS, 27) ${ }^{17}$.

\footnotetext{
${ }^{17}$ [ele, por fim, tomou a decisão mais estranha de que jamais se ouviu, a saber, de viajar pelo mundo inteiro até encontrar um amigo de verdade]; [ele tinha o bom senso de saber que a humanidade em sua natureza é
} 
Através das aventuras de David, o leitor tem acesso a diferentes universos da vida londrina: além da Bolsa de Valores, aparecem também hospedarias, tavernas, o pequeno comércio, o teatro, e casas de famílias ricas, remediadas, e mesmo pobres. Em cada lugar, David observa e se relaciona com as pessoas, procurando nelas a tal amizade sincera que tanto busca. Seu interesse por aqueles que encontra é genuíno, até descobrir que seus interlocutores agem unicamente em benefício próprio. A decepção faz com que David se afaste, troque de moradia provisória e retome a busca.

$\mathrm{O}$ primeiro personagem digno do nome e que corresponde às expectativas do herói de Sarah Fielding é Cynthia - que ele encontra na casa de Lady -------- por intermédio de Mr. Varnish, um conhecido. O herói nota imediatamente a presença de Cynthia quando chega na casa: "Our Hero, on whose Tenderness the least Appearance of Grief in others made an immediate Impression, could not help observing, in the Countenance of this young Creature, a fix'd Melancholy, which made him uneasy"'(DS, 98-99) $)^{18}$. A moça havia sido acolhida por Lady ----------- por “meer Compassion”, pois não era casada e não tinha família com que pudesse viver. E, no entanto, sua benfeitora a acusava de ingratidão, quase traição, apontando "the Ingratitude of those low mean Animals, who were forced to be Dependents" (DS, 99) ${ }^{19}$.

David se interessa ainda mais pela moça e pede para retornar no dia seguinte a fim de ouvir toda a sua história. A "dependente" toma a palavra e narra sua vida ao longo de três capítulos. O que o protagonista - e, por conseguinte, o leitor - descobre na conversa com Cynthia é uma jovem de personalidade forte, bastante consciente dos perigos de se ter inteligência e curiosidade num mundo feito para moças prendadas e casadoiras:

I was bred up with my Father and Mother, who, without designing me any harm, were continually teazing me. I loved reading, and had a great Desire of attaining Knowledge; but whenever I asked Questions of any kind whatsoever, I

basicamente a mesma em todos os lugares; e que se ele pudesse atravessar uma cidade grande e não encontrar uma alma generosa, seria vão continuar a procurar.]

${ }^{18}$ [nosso herói, o qual, por sua ternura, sofria diante da mais leve aparência de sofrimento alheio, não pôde deixar de observar, no rosto desta jovem criatura, uma melancolia que o fez sentir-se pouco à vontade.]

${ }^{19}$ [a ingratidão daqueles animais desprezíveis que eram forçados à dependência] 
was always told, such Things were not proper for girls my age to know: If I was pleased with any Book above the most silly Story or Romance, it was taken from me. For Miss must not enquire too far into things, it would turn her Brain; she had better mind her Needle-work, and such Things as were useful for Women; reading and poring on Books, would never get me a Husband ${ }^{20}$. (DS, 101)

Após relatar sua vida, Cynthia decide se desvencilhar de Lady ---------, aceita a ajuda financeira de David e parte da casa de sua benfeitora para viver no campo, com uma prima. Nosso herói retorna assim para as ruas. Decide hospedar-se num lugar mais simples, com o objetivo de ficar "amongst the Lower sort of People, and see what he could make of them" ${ }^{\prime 21}$ (DS, 126). Não demora muito para que ele encontre seus dois outros amigos: os irmãos Camilla e Valentine.

Os dois irmãos também estão hospedados ali e passam por uma situação que a literatura da época definiria por "complete distress". Valentine está gravemente doente, ambos estão famintos e sem nenhum dinheiro, sendo praticamente expulsos pela dona da pensão por falta de pagamento. A chegada de David resolve tudo. Ele oferece novamente ajuda financeira, procurando aliviar as aflições do doente e de sua irmã. E chega a vez de Camilla contar sua história em outros três capítulos nos quais a palavra lhe é dada:

I spent my Infancy from the time I can remember, very different from what most Children do; it being the usual Method of most of the wise Parents I have ever seen, to use their Little-ones in such a manner, as if they were laying Plots to procure their hearty Aversion to the End of their Lives; but my Father used to say, that as he lived in a Country where Christianity was professed, there was no danger his Posterity would ever be Slaves. He therefore would never use them to the Thoughts of Whips and Rods (...) Indeed he often added, that we did not scruple buying and selling Slaves in our Colonies; but then we took care not to

\footnotetext{
${ }^{20}$ [Fui criada com meu pai e minha mãe, os quais, sem quererem meu mal, viviam implicando comigo. Eu adorava ler, e tinha grande desejo por conhecimento; mas sempre que perguntava algo, me diziam, essas coisas não são para moças de minha idade: se eu gostasse de algum livro superior às histórias mais bobas, este era tomado de mim. Pois a senhorita não deve querer saber muito sobre as coisas, isto lhe viraria a cabeça; era melhor que ela se preocupasse com suas costuras, e outras coisas que eram úteis às mulheres; ler e xeretar nos livros nunca me trariam um marido.]

${ }^{21}$ [entre as pessoas de origem mais baixa, e ver o que ele poderia aprender com eles.]
} 
convert them to our Faith, for it was not lawful to make slaves of Christians ${ }^{22}$. (DS, 134)

Apesar da relação aparentemente privilegiada de Camilla e Valentine com seus pais, a morte de sua mãe e o casamento do pai com Lívia, uma maldosa viúva, acabaram levando os dois irmãos ao rompimento com a família e à fuga. David se sensibiliza muito com a triste narrativa de Camilla e decide permanecer junto aos dois novos amigos. Cynthia volta para Londres e o quarteto, unido desta vez, sai pela cidade observando quadros da vida londrina em que se revezam o bem e o mal.

Durante um destes passeios, Cynthia reconhece, numa hospedaria, uma francesa que tinha encontrado anos atrás durante suas viagens com Lady ------. Isabelle, filha de um certo Marquis de Stainville, está apenas de passagem pela Inglaterra e encontra-se num estado de grande melancolia. A curiosidade dos quatro amigos faz com que Cynthia se aproxime da moça. Isabelle termina por se render ao afã benevolente de David e seus companheiros e se convence a relatar seus infortúnios:

I was bred up from five Years of Age in a Nunnery; nothing remarkable happened to me during my Stay there: but I spent my Time sometimes with my Companions in innocent Amusements (...). At Fourteen, my Father sent for me home (...). I had not been long there, before a Gentleman, who often visited and dined with my Father, made him a Proposal of marrying me (...). This was the first time I had any Opportunity of acting (... ${ }^{23}$. (DS, 196-197)

A "tragical Story" de Isabelle termina com sua volta para a França com a intenção de isolar-se do mundo num convento. David e seus amigos retomam mais uma vez suas

\footnotetext{
22 [Passei minha infância, desde que me lembro, de maneira muito diferente das outras crianças; era método usual da maioria dos pais sábios tratar os pequenos de tal modo que pareciam estar armando planos para que os filhos os odiassem para o resto de suas vidas; mas meu pai costumava dizer que, como ele vivia num país em que se professava o cristianismo, não haveria perigo que seus filhos se tornassem escravos. Logo, ele nunca os trataria com violência (...). De fato, ele sempre acrescentava que não tínhamos escrúpulos em comprar e vender escravos em nossas colônias; mas isso era porque tomávamos o cuidado de não convertêlos à nossa fé, pois não era justo fazer com que cristãos fossem transformados em escravos.]

${ }^{23}$ [Fui criada num convento desde os cinco anos de idade; nada de notável aconteceu comigo durante a minha estadia ali: mas eu passava o tempo com minhas companheiras às vezes em diversões inocentes (...). Aos quatorze anos, meu pai me chamou de volta para casa (...). Eu havia chegado há pouco tempo quando um cavalheiro que visitava e jantava com meu pai freqüentemente, fez-lhe uma proposta de casar-se comigo (...). Foi a primeira vez que eu tive a possibilidade de agir (...).]
} 
aventuras - um passeio de barco pelo Tâmisa, um encontro com um Clergyman que traria notícias do irmão de David, o reencontro com o pai (arrependido) de Camilla e Valentine... Até que o título do capítulo IX (livro IV) indica o final feliz: "Containing two Weddings, and consequently the Conclusion of the Book", ou seja, o duplo casamento de Camilla e David, e de Valentine e Cynthia.

The Adventures of David Simple teve sucesso imediato - a ponto de Sarah F. apresentar-se freqüentemente como "the Author of David Simple" em suas publicações posteriores. O sucesso pode ter igualmente influenciado a autora quando, alguns anos mais tarde, ela opta por retomar as personagens de seu primeiro romance numa seqüência intitulada David Simple, Volume the Last - publicada em $1753^{24}$.

Os nove anos que separam as duas "etapas" da história de David trouxeram mudanças consideráveis na vida de Sarah F. Primeiramente, a escritora deixa a residência londrina de seu irmão Henry Fielding depois que este se casa novamente em 1747. Sarah F. vai morar com as irmãs, Catharine, Beatrice e Ursula, em Westminster. Porém, num período de menos de um ano (de 1750 a 1751), suas três irmãs morrem, provavelmente em decorrência de alguma epidemia.

Além disso, sua situação financeira continua difícil. Neste período, a romancista apóia-se principalmente em sua amiga de infância, Jane Collier, mas também em Richardson, além de contar com o apoio de um pequeno grupo de mulheres intelectuais Elizabeth Carter, Catherine Talbot, as irmãs Elizabeth Montagu e Sarah Scott - que se aproximariam bastante dela no fim de sua vida.

Diante das dificuldades, não seria improvável que, ao retomar a mesma história e os mesmos personagens de seu romance de maior sucesso, Sarah F. procurasse um pouco

\footnotetext{
${ }^{24}$ Em 1747, Sarah Fielding havia publicado Familiar Letters Between the Characters of David Simple and Others. Trata-se de uma coleção de 45 cartas, dois diálogos e uma alegoria moral - material organizado em dois volumes, com a colaboração de Henry Fielding (que forneceu 5 cartas) e de James Harris (autor dos dois diálogos). As Familiar Letters são, às vezes, vistas como a segunda parte da história de David - compondo assim uma "trilogia" juntamente com Volume the Last. Porém, Familiar Letters não contém a seqüência da história de David e seus amigos, usando os personagens apenas como "pretextos" para a composição das cartas. Deste modo, não entra aqui como material de análise. Ver a este propósito BREE, Linda. op. cit., pp. 46-57.
} 
do retorno pecuniário que a primeira parte da história lhe havia proporcionado. No entanto, ainda que Volume the Last apresente o mesmo núcleo familiar - David e sua mulher, Camilla; seu cunhado Valentine e a esposa Cynthia -, o leitor encontra aqui uma narrativa um tanto diversa das Adventures.

Enquanto a primeira parte da história mistura ritmos narrativos diferentes, o volume de 1753 apresenta uma ação mais linear, com a presença constante do narrador. Aparecem menos personagens periféricos; o enredo se concentra na família de David e nas fatalidades que se sucedem. Assim, numa série de eventos desastrosos causados pela falta de dinheiro, pela doença, ou por ambos, a "little family" de David Simple vai se descompondo diante do olhar sarcástico de Mr. e Mrs. Orgueil, ou de Mr. Ratcliff supostos amigos que parecem regozijar-se cada vez que David e os seus sofrem um abalo. O narrador já anuncia, no segundo parágrafo do romance, que o leitor deverá encontrar um mundo ainda mais obscuro do que aquele apresentado nas Adventures:

A Man, actuated by neither Avarice nor Ambition, his Mind moving on no other Axis but that of Love, (...) seeing, at the same time, all his Friends chearful and pleased around him, seems to be in a State of Happiness, in comparison of which, every thing in this World is trifling. And in this agreeable Situation did David Simple and his Friends continue (with the Exception only of some pecuniary Losses, which could not destroy Felicity so founded) for the space of eleven Years: which Time I shall pass over with as much Brevity as possible, so as to lead my Reader to the Beginning of that Year, in which David Simple began to be convinced that although no Scheme for Happiness could be built on a better Foundation than his; (...) yet there may be such a Concurrence of Events, such heart-rending Scenes, arising from this very friendly Connection, as must undeniably prove the Truth of that Observation, so common both in the Writings and Conversations of Mankind, namely, 'That solid and lasting Happiness is not to be attained in this World'25. (VL, 313-314)

\footnotetext{
${ }^{25}$ [Um homem que não é movido nem pela avareza, nem pela ambição, sua mente não se movendo em nenhum outro eixo a não ser o do amor, (...) vendo, ao mesmo tempo, todos os seus amigos alegres e satisfeitos à sua volta, parece estar num estado de felicidade cuja comparação com qualquer coisa neste mundo faz com que a última pareça trivial. E David e seus amigos continuaram nesta situação agradável (com a exceção de algumas perdas pecuniárias que não poderiam acabar com felicidade tão bem fundada) durante o período de onze anos: período pelo qual devo passar com maior brevidade possível, para conduzir meu leitor ao início daquele ano em que David Simple começou a se convencer de que, apesar de nenhum esquema de felicidade se construir sobre melhores bases do que as suas; (...) ainda assim, pode ocorrer uma série de eventos, cenas tão entristecedoras, resultando desta mesma relação amigável, que fica provada a verdade da observação, tão comum em escritos e conversas humanas, a saber, 'que não se chega à felicidade sólida e duradoura neste mundo'.]
} 
Já que a felicidade não era possível neste mundo, as pequenas tragédias se acumulam. O casal Cynthia e Valentine vai buscar fortuna na Jamaica, deixando a filha, "little Cynthia", aos cuidados de David e Camilla. A menina acaba morrendo em função de maus tratos recebidos de Mrs. Orgueil durante uma estadia em Bath; Valentine morre na Jamaica, deixando Cynthia sozinha e em dificuldade. A situação financeira da família vai se deteriorando, e os Simple se mudam para casas cada vez menores, até que a última pega fogo - e a família perde tudo o que lhe restava.

Do grupo familiar inicial, restam "little Camilla" - a única sobrevivente dos cinco filhos de David e Camilla - e Cynthia, que volta da Jamaica a tempo de acompanhar o herói em seus últimos momentos. É ela quem procura apoio para si e para sua sobrinha junto a uma família sua conhecida, residente nas proximidades de Bath. David dá seu último suspiro depois de fazer um balanço amargo de sua existência:

When I revolve in my Thoughts all my past Life, the Errors of my Mind strike me strongly. (...) Had any one then attempted to persuade me, how little could I have believed, that the attaining a faithful and tender Friend, that strong Pursuit of my Life, and which I thought the Height of Happiness, should lead to its very contrary, and by that Means shew me the Short sightedness of all human Wisdom (...). (VL, 430) 26

Tiradas as devidas lições, o narrador deixa nas mãos do leitor a possibilidade de "drag David Simple from the Grave",27 para fazê-lo refletir, novamente, sobre o mundo e suas ilusões.

Volume the Last teve menos sucesso e suscitou menos interesse do que as Adventures of David Simple - o que, para alguns, deveu-se mais à estratégia de publicação do romance do que propriamente à sua qualidade. De todo modo, o primeiro David Simple e a sua continuação foram os principais romances de Sarah F., além de

\footnotetext{
${ }^{26}$ [Quando examino em meus pensamentos toda minha vida passada, os erros de minha mente me golpeiam muito. (...) Se alguém tivesse tentado me persuadir, quão pouco eu teria acreditado, que, conseguir um amigo fiel e terno, a grande busca da minha vida, e que eu imaginava ser o ápice da felicidade, conduziria ao exato oposto, e por esse meio mostrar-me-ia a miopia de toda sabedoria humana (...).]

${ }^{27}$ [tirar David Simple do túmulo].
} 
Little Female Academy, que ficaram para a posteridade. Foram lidos, em geral, como uma única história escrita pela irmã de Henry Fielding e como um dos primeiros textos da época em que se revelam os "labirintos do coração"28.

O interesse da crítica por David Simple tem aumentado nos últimos anos, especialmente a partir de pesquisas que se concentram no processo de formação e consolidação do romance como gênero na Inglaterra setecentista, assim como no papel exercido pelas mulheres escritoras neste movimento. Quando observadas em conjunto, as duas partes da história de David e seus amigos parecem oferecer elementos novos para a compreensão deste período da história do romance. Resta investigar quais elementos são pertinentes e expõem, de fato, uma perspectiva inovadora acerca da formação do gênero. É este o objetivo principal deste trabalho.

\footnotetext{
${ }^{28}$ Os poucos dicionários de literatura inglesa que mencionam Sarah Fielding - como, por exemplo, The Concise Oxford Companion to English Literature, editado por M. Drabble e J. Stringer -, resumem neste tom a temática do romance.
} 
Capítulo 1: No qual são relatadas as primeiras Impressões acerca de nosso Romance 


\section{Primeiras Impressões}

"It is a trite but true Observation, that Examples work more forcibly on the Mind than Precepts: (...) A good Man therefore is a standing Lesson to all his Acquaintance, and of far greater use in that narrow Circle than a good Book."

(Henry Fielding, Joseph Andrews)

1. Os "primeiros críticos": Henry Fielding e Samuel Richardson

A primeira parte da história de David, The Adventures of David Simple, teve grande sucesso. A recepção de sua primeira edição em 1744 foi tão positiva que Henry Fielding apressou-se em escrever, para a segunda edição - lançada no mesmo ano -, um prefácio em que explica as razões que o levaram a apresentar a obra. Na realidade, $\mathrm{H}$. Fielding usa o prefácio primeiramente como veículo para se defender das acusações de ser o autor de textos satíricos - e, segundo ele, blasfematórios - que circulavam no mercado literário londrino.

Ao mesmo tempo, afirma que ficou honrado de ter sido erroneamente considerado o autor deste romance em particular. E comenta: " $A$ third, and indeed the strongest Reason which hath drawn me into Print, is to do Justice to the real and sole Author of this little Book; who, notwithstanding the many excellent Observations dispersed through it, and the deep Knowledge of the Human nature it discovers, is a young Woman (...)"29.

\footnotetext{
${ }^{29}$ [a terceira e mais forte razão que me levou a escrever [este prefácio] é fazer justiça à verdadeira e única autora deste livrinho; a qual, apesar das várias excelentes observações espalhadas no livro, e do profundo conhecimento da natureza humana, é uma jovem moça (...).] FIELDING, Henry. "The Preface". In: FIELDING, Sarah. op. cit., p. 5. O texto satírico a que provavelmente se refere H. Fielding é The
} 
Samuel Richardson, que publicara quatro anos antes a sua Pamela, também havia sido aparentemente seduzido pelo estilo da escritora - a ponto de confessar, em carta escrita a Sarah F. em dezembro de 1754: "What a knowledge of the human heart! Well might a critical judge of writing say, as he did to me, that your late brother's knowledge of it was not (fine writer as he was) comparable to yours. His was but a knowledge of the outside of a clockwork machine, while yours was that of all the springs and movements of the inside" 30 .

As expressões utilizadas por H. Fielding e Richardson em seus comentários expõem a clivagem essencial que marcaria a rivalidade entre os dois romancistas: para o primeiro, Sarah F. é grande conhecedora da "human Nature", enquanto para o segundo, a autora tem acesso privilegiado ao "human heart". Cada um observa, a seu modo, o que lhe convém destacar na obra de Sarah Fielding. Não é difícil reconhecermos, nos trechos acima, as duas visões do mundo e do romance encarnadas pelos dois homens.

Já no prefácio a Joseph Andrews (1742), Henry Fielding dava sinais claros de uma tentativa de aproximação entre a tradição clássica e o romance através da expressão “poema épico em prosa". Com ela, o romancista buscava resumir seu "projeto" literário, a saber:

(...) criar uma forma artística correspondente ao que fora a epopéia para o mundo antigo, isto é, um espelho realista e uma reflexão crítica sobre a vida de seu tempo. Privada da métrica mas dotada das outras partes constitutivas de sua contrapartida clássica (fábula, ação, personagens, sentimento e dicção), essa epopéia moderna - 'até agora [não] tentada em nossa língua' - supunha uma ação extensa e abrangente, um círculo grande de incidentes e uma maior variedade de personagens do que apresentava a comédia. Mas se propunha

Causidicade. Panegyri-Satiri-Serio-Comic-Dramatical Poem - agora atribuído a Macnamara Morgan no qual o autor anônimo atacava vários advogados proeminentes no cenário jurídico londrino.

${ }^{30}$ [Que conhecimento do coração humano! Bem pôde um crítico dizer, como disse a mim, que o conhecimento que seu finado irmão tinha [do coração humano] (fino escritor que era) não se comparava ao seu. O dele era um conhecimento das partes externas do relógio, enquanto o seu era o de todos os mecanismos internos.] SPENDER, Dale. Mothers of the Novel, London: Pandora, 1986. p. 185. O comentário de Richardson repete o que Samuel Johnson - o tal "critical judge of writing" - havia afirmado para confirmar sua preferência pelo autor de Pamela em detrimento de H. Fielding. Ian Watt menciona uma outra declaração de Johnson que confirma a primeira: "Richardson pegou o caroço da vida (...) enquanto Fielding se contentou com a casca". In: WATT, Ian. A Ascensão do Romance, São Paulo: Companhia das Letras, 1996. p. 227. 
como 'cômica', explicava o escritor em seu prefácio [a Joseph Andrews], porque visava à apresentação de pessoas de extração social baixa e, conseqüentemente, de costumes 'inferiores', e a uma representação realista do mundo ${ }^{31}$.

O objetivo parecia ser, portanto, retomar o enredo da epopéia como um "amplo panorama de toda uma sociedade ${ }^{, 32}$, fazendo evoluir dentro deste personagens cuja função primordial seria contribuir para a visão global, por parte do leitor, da "natureza" e dos "costumes" característicos daquele universo. A comicidade ficaria por conta da exposição dos "vícios", cujo retrato se tornava inevitável em função do argumento relativo à fidelidade (ou verossimilhança) no tocante à "natureza".

Estas idéias são retomadas no prefácio a David Simple, já que o autor parece considerar o romance escrito por sua irmã como mais um representante da forma herdada - e reciclada - dos antigos:

I have attempted in my Preface to Joseph Andrews to prove, that every Work of this kind is in its Nature a comic Epic Poem, of which Homer left us a Precedent, tho' it be unhappily lost.

The two great Originals of a serious Air, which we have derived from that mighty Genius, differ principally in the Action, which in the Illiad is entire and uniform; in the Odyssey, is rather a Series of Actions, all tending to produce one great End. Virgil and Milton are, I think, the only pure Imitators of the former; most of the other Latin, as well as Italian, French, and English Epic Poets, chusing rather the History of some War, as Lucan and Silius Italicus; or a Series of Adventures, as Ariosto, \&c. for the Subject of their Poems.

In the same manner the Comic Writer may either fix on one Action, as the Authors of Le Lutrin, the Dunciad, \&c. or on a Series, as Butler in Verse, and Cervantes in Prose have done.

\footnotetext{
${ }^{31}$ VASCONCElos, Sandra G. T. Dez Lições sobre o Romance Inglês do Século XVIII. São Paulo: Boitempo Editorial, 2002. pp. 86-87. Ian Watt observa, no entanto, que as idéias expostas por Fielding neste prefácio não devem ser levadas tão a sério, especialmente se considerarmos que sua formação e suas leituras não o impediram de estabelecer relações um tanto quanto confusas entre romances heróicos franceses como Telêmaco, de Fénélon, e a Odisséia de Homero... Para Watt, Joseph Andrews e seu prefácio foram provavelmente elaborados "às pressas" - com a motivação inicial de funcionar como uma paródia de Pamela -, o que desabona de certo modo a seriedade das "teorias" do autor. Ver a este respeito WATT, Ian. "Fielding e a Teoria Épica do Romance", op. cit., pp. 208-225.

${ }^{32}$ WATT, Ian. op. cit., p. 219.
} 
Of this latter kind is the Book now before us, where the Fable consists of a Series of separate Adventures detached from, and independent on each other, yet all tending to one great End; so that those who should object want of Unity of Action here, may, if they please, or if they dare, fly back with their Objection, in the Face of even the Odyssey itself. ${ }^{33}$

Portanto, do ponto de vista de H. Fielding, The Adventures of David Simple corresponderia exatamente ao modelo proposto por ele próprio em seu Joseph Andrews ao retomar o que ele entende por tradição épica, a saber: o antigo tema da viagem, e a narração de aventuras e encontros com personagens de diferentes extratos sociais numa série de episódios independentes que caminham para um grande final. A base do romance de Sarah F. estaria, neste sentido, no desenvolvimento de um enredo rico, estruturado à moda de Homero - o que dispensaria questionamentos a respeito de sua unidade. Assim, fica claro que, para H. Fielding, é o enredo que tem a prioridade sobre os personagens em David Simple.

Não é de se estranhar, deste modo, que Henry Fielding enfatize, no tocante aos personagens do romance de Sarah F., o fato de que estes são típicos representantes do que ele chama de "natureza". Assim, aparecem em David Simple pinceladas de orgulho, de cinismo, de vaidade, que poderiam estar presentes, segundo ele, em Horácio, La Bruyère, ou mesmo em Shakespeare. Além disto, os sentimentos expressos, reconhece Fielding, são de extrema delicadeza, tendo em vista que a autora teve o cuidado de bem adaptar seus personagens a eles.

\footnotetext{
${ }^{33}$ [Eu procurei, em meu Prefácio a Joseph Andrews, provar que toda obra deste tipo é, por natureza, um poema épico-cômico em prosa, do qual Homero nos deixou um precedente, infelizmente perdido. Os dois grandes originais sérios, que derivamos deste gênio, se diferenciam especialmente pela ação, a qual, na Ilíada, é inteira e uniforme; na Odisséia, trata-se, ao contrário, de uma série de ações, todas caminhando para um grande final. Virgílio e Milton são, acredito eu, os únicos puros imitadores do primeiro; a maioria dos outros poetas épicos latinos, mas também italianos, franceses e ingleses, escolheram a história de alguma guerra, como Lucan e Silius Italicus; ou uma série de aventuras, como Ariosto, \&c. como assunto de seus poemas. Da mesma maneira o autor cômico pode se concentrar em uma ação, como os autores de Le Lutrin ou de Dunciad, \&c. ou em uma série, como Butler fez em verso, e Cervantes em prosa. Do último tipo é o livro que temos diante de nós, no qual a fábula consiste numa série de aventuras separadas, desligadas e independentes uma da outra, e no entanto todas conduzindo a um grande final; de modo que aqueles que objetarem falta de unidade de ação aqui podem, se ousarem, retificar suas objeções diante da própria Odisséia.] FIELDING, Henry, "The Preface", In: FIELDING, Sarah. op. cit., p. 6.
} 
Estes comentários de Fielding corroboram o tratamento dado à caracterização em seus próprios romances. Como explica Ian Watt, o romancista está interessado em colocar os personagens dentro de categorias, focalizando uma ordem social maior em detrimento da individualização e da profundidade subjetiva. O "realismo" de Fielding ou, se quisermos, seu modo de contar a "verdade" - passa, assim, pela estruturação de um enredo que demonstre "o funcionamento da ordem universal" 34 . Sarah F. teria encontrado nesta forma o recorte para lidar com os materiais que a realidade lhe oferecia.

O elogio do autor de Clarissa vai por outro caminho. Ao ressaltar os conhecimentos de Sarah sobre o coração humano, ele retoma o comentário de Samuel Johnson em que este exprime sua preferência pelo tratamento dado aos personagens nos romances de Richardson. A opção do romancista pela estrutura epistolar possibilitou o acesso à vida interior dos personagens - com todos os problemas de ambigüidade que implica e que o autor procurou, em vão, remediar. Isto significa a eliminação da figura de um narrador presente e que organiza a narrativa; tudo que o leitor tem diante dos olhos são as palavras e os sentimentos das pessoas envolvidas na trama, todas "writing to the moment".

Por um lado, pode-se afirmar que Richardson retoma, em tom secularizado, uma certa tradição de escritos confessionais, especialmente na forma de diário, estimulados pela ideologia puritana desde o século XVII. Ao mesmo tempo, já existia na Inglaterra uma circulação de ficção epistolar popularesca, sob a fachada de cartas "roubadas" - com títulos como A Poste with a Packet of Mad Letters (1603), de Nicholas Breton ${ }^{35}$-, cartas de viagem e, claro, cartas de amor - como as célebres Lettres Portugaises (1699).

Por outro lado, pode-se encontrar este mesmo tipo de mergulho forçado do leitor na subjetividade dos personagens em outro gênero que se desenvolvia paralelamente ao romance no momento de ascensão da burguesia na Europa - em especial na Inglaterra, na França e na Alemanha - de modo marcante a partir do início do século XVIII: o drama burguês. Um breve paralelo entre o tipo de prática ficcional de Richardson e os elementos

\footnotetext{
${ }^{34}$ WATT, Ian. op. cit., pp. 235-236.

${ }^{35}$ Ver MONTANDON, Alain. Le Roman au XVIIIe siècle en Europe, Paris : PUF, 1999. p. 239.
} 
fundamentais do drama burguês pode contribuir para identificarmos melhor o que estava em jogo na relação entre este tipo de ficção e o seu público leitor.

O drama é, de fato, a forma teatral cuja vitalidade repousa na subjetividade:

(...) [o gênero] tem por objetivo a configuração de relações intersubjetivas através do diálogo. O produto dessas relações intersubjetivas é chamado ação dramática e esta pressupõe a liberdade individual (o nome filosófico da livre iniciativa), os vínculos que os indivíduos têm ou estabelecem entre si, os conflitos entre as vontades e a capacidade de decisão de cada um. Através do diálogo, as relações vão se criando e entrelaçando de modo a produzir uma espécie de tecido, por isso mesmo chamado enredo ou entrecho $(. . .)^{36}$.

Os personagens do drama são, portanto, indivíduos bem caracterizados através da profundidade psicológica e é o diálogo entre eles que determina o enredo e o tempo da ação. Além disso, o drama é autônomo, na medida em que é "exposto", não admitindo um narrador. Mais ainda: na relação com o espectador, este gênero "exige identificação absoluta com o personagem "37. Estamos diante do mesmo mecanismo quando lidamos com a prosa de Richardson.

E a reação dos leitores era imediata, como atestam a interminável correspondência de Richardson, as paródias, as críticas, e a parafernália de "produtos" que foram colocados à venda depois do sucesso de Pamela ${ }^{38}$. Assim é que entendemos a intensidade com que Diderot, em seu "Elogio" ao autor inglês, expressa suas sensações como leitor de Clarissa: "Ó Richardson! A gente assume, a despeito do que se é, um papel em tuas

\footnotetext{
${ }^{36}$ COSTA, Iná Camargo. Sinta o Drama. Petrópolis: Editora Vozes, 1998. p. 56.

${ }^{37}$ COSTA, Iná Camargo. op. cit., p. 58.

38 "Fashionable ladies displayed copies in public places, and held fans painted with pictures of its [Pamela] best-loved scenes. Pamela became a play, an opera, even a waxwork; and in a society suspicious of fiction had the distinction of a recommendation from a London pulpit". [Senhoras em dia com a última moda exibiam cópias (do romance) em lugares públicos, e carregavam leques com as cenas mais admiradas. Pamela tornou-se uma peça de teatro, uma ópera, até uma estátua de cera; e, numa sociedade que suspeitava da ficção, (Pamela) tinha a distinção de ter sido recomendado por um púlpito londrino.] KINKEAD-WEEKES, Mark, “Introduction”, Pamela, London: Everyman's Library, 1966. In: EAGLETON, Terry. The Rape of Clarissa, University of Minnesota Press, 1982. p. 5.
} 
obras, a gente se intromete na conversação, aprova, culpa, admira, irrita-se, indigna$s e^{, 39}$.

A "verdade", nos romances de Richardson, se manifestaria, portanto, através desta expressão mais fina dos movimentos do coração, o que significa um nível de profundidade subjetiva da vivência cotidiana impensável dentro da perspectiva de $\mathrm{H}$. Fielding. Para Richardson, o personagem se encontra no centro da estrutura narrativa; é através dele que o romancista dá sentido à experiência. E é este aspecto que mais chama a sua atenção nos romances de Sarah Fielding.

Assim, vemos que David Simple suscita grande empatia nos dois grandes romancistas canônicos na Inglaterra de meados do século XVIII, pois cada um reconhece ali elementos de suas trajetórias e escolhas literárias. Isto significa, em última instância, que para cada um deles a autora Sarah Fielding parece optar por recortes temáticos e formais essencialmente diferentes. Dito de modo esquemático, Sarah F. parece ter priorizado, de um lado, a estrutura episódica - reproduzindo o ritmo de um mundo claramente tradicionalista, em que prima a conservação do status quo fundamentalmente aristocrático e no qual a organização social com base nas origens familiares prevalece sobre o indivíduo; de outro, uma ficção intimista que funciona no ritmo da batida do coração do indivíduo burguês, e no qual a virtude é o valor essencial, em detrimento das origens e do nascimento.

Sabemos, no entanto, que esses dois mundos se acotovelavam naquele momento juntamente com outros, resíduos de outras épocas. Também parece curioso que um mesmo romance abra possibilidades interpretativas de tal modo divergentes. Isto, somado às evidências biográficas - a proximidade pessoal de Sarah F. com Richardson e H. Fielding -, pode levar o crítico rapidamente a uma conclusão bastante lógica: o romance de Sarah Fielding seria um amálgama dos modelos encontrados em suas duas grandes referências, uma cópia que procuraria reproduzir, numa mistura nem sempre bemsucedida, os "formatos" encontrados pelos dois autores. Tomada como pressuposto

\footnotetext{
39 DIDEROT, Denis. "Elogio a Richardson" (1762), in: Diderot, Obras Poéticas II - Estética, Poética e Contos. GUINSBURG, J. (org.) São Paulo : Perspectiva, 2000. p. 17.
} 
crítico - de certo modo estimulado e reforçado pelos comentários de Richardson e Fielding -, a idéia da cópia foi o principal caminho adotado pela crítica e continua fazendo escola ${ }^{40}$.

2. Kelsall e Watt

Malcolm Kelsall, autor da introdução à edição das Adventures de David Simple publicada em 1969, é o primeiro crítico nosso contemporâneo a adotar a premissa da cópia. Kelsall inicia seu ensaio com alguns dados biográficos, entre os quais insiste na difícil situação financeira de Sarah F. - "her life was passed in dependency"41 - e na importância do irmão Henry Fielding em sua carreira literária, como conselheiro, revisor e "avalista". Ao tratar especificamente do romance, o crítico avisa, logo de saída, que o leitor ficaria sem dúvida decepcionado se procurasse ali traços da grandeza de Richardson ou de Fielding:

Richardson's implication is that Sarah Fielding is a psychological novelist of the same kind as himself. To read her works with this expectation, however, is to be disappointed. Her hero, David Simple, scarcely succeeds in being a person at all. Miss Fielding is admirable at detecting and analyzing malignity and pride cloaked by hypocrisy within the human heart, but she does not dramatize what she analyses. Although the influence of her brother led her to give the original novel an episodic structure in which the reader would see both high and low life,

\footnotetext{
${ }^{40}$ Ver a este respeito TERRY, Richard. "David Simple and the Fallacy of Friendship", in: SEL, Volume 44, Number 3, Summer 2004, pp. 525-544. Terry afirma: "Making a case for Sarah Fielding as a novelist of consequence in her own right has understandably entailed minimizing the influence exercised on her by Henry. However, I will suggest that the debate conducted about friendship across both parts of David Simple owes a significant amount to how the issue is treated in the various literary materials comprising her brother's three-volume Miscellanies, published in 1743, a year before Sarah's David Simple" [Defender Sarah Fielding como romancista levou a crítica a minimizar a influência que Henry exerceu sobre ela. No entanto, argumentarei que o debate conduzido sobre a amizade nas duas partes de David Simple se deve, em grande parte, ao modo como o assunto é tratado nos vários materiais literários incluídos nos três volumes de seu irmão, as Miscellanies, publicado em 1743, um ano antes de David Simple.] (p. 526).

${ }^{41}$ [Sua vida foi marcada pela dependência.] KELSALL, Malcolm. "Introduction", in: FIELDING, Sarah. The Adventures of David Simple, London: Oxford University Press, 1973. p. x.
} 
she is not interested in the portrayal of manners and mannerisms. She is not really a novelist at all $(\ldots)^{42}$.

O crítico aponta, portanto, dois problemas que teriam conduzido a autora a perder o controle sobre o seu material, inviabilizando assim sua narrativa como romance. $\mathrm{O}$ primeiro deles seria a incapacidade de Sarah F. de dramatizar o que consegue observar na realidade das relações entre os homens - ou seja, a falta de habilidade na cópia do modelo de Richardson. Referindo-se a outro romance de Sarah F. - The History of the Countess of Dellwyn (1759) -, Kelsall se espanta com o que chama de recusa, por parte da romancista, de "render the substance of life dramatically in a tale which could have been an English Anna Karenina or Madame Bovary"43.

A técnica de caracterização em David Simple se afastaria assim do estilo richardsoniano. Ao mesmo tempo, pouco teria em comum com o tratamento dado aos personagens nos romances de Henry Fielding - Kelsall reconhece na narrativa de Sarah F. um estilo de caracterização semelhante ao de Steele ${ }^{44}$. Isto significa que a autora teria mais capacidade para lidar com tipos morais funcionando numa estrutura alegórica - o

\footnotetext{
42 [ A dedução de Richardson é que Sarah Fielding é uma romancista psicológica, do mesmo tipo que ele. Ler suas obras com esta expectativa, no entanto, causa desapontamento. Seu herói, David Simple, quase não consegue ser uma pessoa. Miss Fielding é admirável quando detecta e analisa a maldade e o orgulho encerrados pela hipocrisia no coração humano, mas ela não dramatiza o que analisa. Apesar de a influência de seu irmão tê-la levado a dar ao romance original uma estrutura episódica na qual o leitor veria a vida das classes altas e das classes baixas, ela não está interessada no retrato dos costumes e dos maneirismos. Realmente não se trata de uma romancista.] KELSALL, Malcolm. "Introduction", in: FIELDING, Sarah. op. cit. p. xii. É preciso reconhecer, no entanto, que Kelsall reviu algumas de suas posições sobre Sarah e sua obra no "Bibliographical Essay" publicado pela Oxford Classics junto com a edição de 1987 do romance. Diz ele: "There have been substantial advances in scholarship since then, and radical changes in critical methodologies." Mas ainda assim: "But I am unrepentant in my former emphasis on the importance of her elder brother on the career of Sarah Fielding". [Houve avanços substanciais nos estudos desde então, e mudanças radicais nas metodologias críticas. (...) Mas não me arrependo da ênfase dada anteriormente à importância de seu irmão mais velho na carreira de Sarah Fielding.] (pp. xxiv-xxv).

${ }^{43}$ [ de oferecer a substância da vida dramaticamente numa história que poderia ter sido um Anna Karenina ou um Madame Bovary inglês.] KELSALL, Malcolm. "Introduction", in: FIELDING, Sarah. op. cit. p. xii.

${ }^{44}$ Richard Steele (1672-1729) iniciou em abril de 1709 um periódico entitulado The Tatler, publicado duas vezes por semana até janeiro de 1711. Esta publicação foi seguida pelo Spectator, que saía diariamente - e para o qual colaborava também Joseph Addison - até dezembro de 1712. Os dois periódicos, apesar da curta "vida", tiveram grande influência na formação da nova opinião pública que tomava forma na sociedade londrina - especialmente nos cafés (as chamadas coffeehouses).
} 
que caracterizaria sua prosa de fato como "ficção moral" - do que propriamente para criar personagens mais complexos dentro de um enredo elaborado.

De fato, se observarmos o estilo de caracterização de algumas narrativas curtas de Steele, não podemos negar que procede a aproximação com Sarah Fielding. Uma história publicada no Spectator começa deste modo:

A friend of mine has two daughters, whom I will call Laetitia and Daphne: the former is one of the greatest beauties of the age in which she lives, the latter no way remarkable for any charms in her person. Upon this one circumstance of their outward form, the good and ill of their lives seems to turn ${ }^{45}$.

No quarto capítulo da primeira parte de David Simple, Cynthia narra a história de duas irmãs que havia conhecido durante as viagens com Lady

There were two young English Ladies at Paris, with a married Lady of their Acquaintance, who were celebrated for their Beauty throughout the whole Town; one of them was named Corinna, and the other Sacharissa: and notwithstanding they were Sisters, yet were they as perfectly different in both Person and Temper, as if they had been no way related ${ }^{46}$. (DS, 256)

Parece interessante observar traços da influência das leituras de Steele na produção de Sarah F., especialmente no que se refere à habilidade que ambos demonstram de manejar uma estrutura narrativa - a alegoria moral - e um tipo de personagem cujo apelo ao público leitor da época tinha sua força. Por outro lado, talvez seja precipitado imaginar que este aspecto defina o tratamento global dado à caracterização pela autora em seu primeiro romance. O próprio Kelsall não persegue este

\footnotetext{
${ }^{45}$ [Um amigo meu tem duas filhas que chamarei de Laetitia e Daphne: a primeira é uma das maiores belezas de sua época, a última de modo algum chama a atenção por seus encantos. Em função desta única circunstância de sua aparência exterior, define-se o bem e o mal nestas moças.] Steele, Richard. Selections from the Spectator, Tatler, Guardian and Freeholder: With a Preliminary Essay. No. 82, pp. 21-26. http://books.google.com/, acessado dia 19/06/2006.

${ }^{46}$ [Havia duas jovens inglesas em Paris, acompanhadas de uma senhora casada, e que eram celebradas por sua beleza em toda a cidade; uma se chamava Corinna, e a outra, Sacharissa: e, apesar de serem irmãs, eram extremamente diferentes em aparência e temperamento, a ponto de não parecerem ter nenhum parentesco.]
} 
argumento até as últimas conseqüências e retoma o critério da influência do irmão Henry Fielding ao buscar analisar mais em detalhe o protagonista David.

Este é visto por Kelsall como uma versão fraca de Heartfree - personagem de Jonathan Wild $(1743)^{47}$. Segundo o crítico, sua simplicidade se deve à ausência de duplicidade. Por ser ingênuo, David poderia ter funcionado como o veículo para uma crítica irônica e mordaz da sociedade inglesa. No entanto, afirma Kelsall, a escolha de Sarah F. em conceber sua narrativa como um 'Romance' faz com que o elemento de sátira seja eliminado de seu personagem e que este acabe se transformando em um sentimental que só procura, na realidade, uma esposa.

O segundo problema se refere ao fato de que a estrutura episódica - influência de Henry Fielding que possibilitaria um retrato dos modos e hábitos daquela sociedade acaba não atingindo o efeito esperado. Isto porque, apesar de Sarah F. ter herdado de seu irmão este modelo de enredo, assim como a idéia do herói peripatético, a tendência da autora a "romancear" $" 48$ seria forte demais. Este argumento explicaria o final abrupto dado à narrativa, com os dois casamentos entre David e Camilla, e Valentine e Cynthia. Sarah Fielding teria se rendido às convenções "românticas" (sic) na falta de saber, exatamente, que fim dar para fazer passar sua mensagem com justeza. É interessante notar, no entanto, que, ao apontar estes problemas, Malcolm Kelsall percebe que existem, dentro da narrativa, dois ritmos diversos. Diz ele: "until the break into romance there was a different logic in the structure of the story"49. Aparentemente, no jogo entre retrato

\footnotetext{
${ }^{47}$ Neste romance, Henry Fielding faz uma sátira dos romances biográficos e do que se costuma chamar de crime literature, em moda na época, escolhendo como personagem principal um criminoso notório - que realmente existiu - cuja atividade principal consistia em roubar (junto com uma equipe de "assessores") para em seguida devolver os bens à vítima mediante o pagamento de uma "taxa". O ladrão que se recusasse a colaborar era entregue às autoridades, e assim é que Wild tornou-se conhecido como "The Thief-Taker General". Wild foi enforcado em 1725. O que interessa a Fielding não é tanto a verdadeira personalidade do bandido, e sim a sua imagem mítica, a qual o romancista utilizaria para escrever sua sátira ao mundo político londrino - atacando especialmente a figura de Walpole. O personagem Heartfree é descrito pelo narrador como "possessed of several great weaknesses of mind, being good-natured, friendly and generous to a great excess" e "so silly a fellow that he never took the least advantage of the ignorance of his customers". [possuía várias grandes fraquezas da mente, sendo excessivamente amigável, generoso e de boa índole. (...) um sujeito tão bobo que nunca tirou a menor vantagem da ignorância de seus fregueses.] In: /www.cherster.ac.uk/english/ acessado em 12/06/2005.

${ }^{48}$ Kelsall fala de "irresistible pull of romance".

49 [até a entrada no 'romantismo', havia uma lógica diferente na estrutura da história.] KELSALL, Malcolm. "Introduction", in: FIELDING, Sarah. op. cit. p. xiv. Traduzi "romance" como "romantismo"
} 
irônico da sociedade e história de amor - como ele identifica os dois ritmos dentro do romance - não há conciliação.

Kelsall aponta, deste modo, o que considera os erros e as potencialidades não exploradas por Sarah Fielding neste romance de 1744 e cuja elaboração seria mais bem sucedida, segundo o crítico, em Volume the Last - a continuação publicada em 1753. É nesta última parte da história de David que o crítico identifica uma estrutura de alegoria moral elegantemente construída; um uso controlado das convenções; as ambigüidades da simplicidade do personagem principal mais plenamente exploradas. E, mesmo se há um pouco de romance no final - elemento que claramente desvaloriza a narrativa, do ponto de vista de Kelsall -, isto não invalida a ironia no discurso do protagonista, funcionando como expressão "saborosa" do "pessimismo augustano".

O crítico se refere aqui à denominação, dentro da história "oficial" da literatura inglesa, de um certo estilo tido como característico de alguns autores de fins do século XVII, início do XVIII - Pope, Swift e Gay, mas também Addison e Steele - cuja produção estaria afinada com os poetas do período augustano do Império Romano (27 a.C. - 14 d.C.). De Virgílio, Horácio e Ovídio, estes autores ingleses setecentistas teriam herdado o gosto pela "Natureza" como fonte de inspiração - assim como as formas consagradas da literatura clássica - em oposição ao estilo "moderno", representado por autores como John Dennis, Sir Richard Blackmore, ou Charles Gildon.

Desta maneira, a prosa de Sarah Fielding - na medida em que se aproxima do estilo de seu irmão Henry F. - seguiria a linhagem de Swift e Gay no sentido de poder ser compreendida na continuidade das formas da tradição clássica, ao mesmo tempo em que satiriza os modos e comportamentos associados aos Whigs (cujo poder e influência teriam aumentado consideravelmente após a Revolução de 1688). O "pessimismo" que

porque entendo que Kelsall não procura se referir, ao utilizar este termo, à categoria do "romanesco", já que a diferença entre romance e romanesco não faz parte da argumentação de sua Introdução a David Simple. Ao mesmo tempo, não parece que o crítico utilize o termo para aproximar o romance de Sarah F. das produções literárias que comumente são "classificadas", dentro de uma perspectiva cronológica da história da literatura, no romantismo como "movimento literário". Tudo parece indicar que Malcolm Kelsall utiliza "romance" no sentido comum da palavra, para identificar as relações amorosas entre os dois casais - David e Camilla, Valentine e Cynthia -, que teriam mudado o foco do romance de Sarah F. 
Malcolm Kelsall identifica em Volume the Last teria as mesmas origens, portanto, da sátira corrosiva que caracteriza The Beggar's Opera ou Jonathan Wild ${ }^{50}$.

O que nos interessa, de início, é discutir a idéia de "romance-cópia" - ou mesmo de cópia mal feita -, que está no centro da argumentação de Kelsall. Primeiramente, é preciso fazer uma concessão - ao menos parcial - ao crítico. Esta concessão se impõe no seguinte sentido: seria difícil negar que a questão da influência dos dois autores canônicos se apresenta como critério quase irresistível para a análise de David Simple, devido à posição de Sarah Fielding como irmã, amiga e leitora daqueles que são vistos como pilares da estruturação do novo gênero na Inglaterra. Dito de outro modo: a análise de Kelsall dá a entender que o dado biográfico é o elemento definidor da intervenção técnica da autora sobre seu material - o que deve ser em parte verdadeiro.

Mas não inteiramente. A argumentação do crítico explica o lado individual da história. Ocorre que as obras literárias não se formam nesta espécie de "vácuo histórico" que parece agradar a uma certa perspectiva tradicional; são elaboradas, ao contrário, em condições sociais precisas que se definem também pelas relações de produção estabelecidas numa dada sociedade. O romance de Sarah Fielding não escapa a este destino. Assim, é tarefa da crítica procurar identificar não somente a posição da obra no que se refere às relações de produção de seu tempo, mas também seu lugar em meio $\operatorname{destas}^{51}$.

Ora, como sabemos, Sarah Fielding escrevia essencialmente porque precisava de dinheiro. Se a escrita de romances lhe parecia uma fonte de renda plausível, não seria

\footnotetext{
50 Esta filiação à tradição greco-romana garantiria ainda, à literatura inglesa, uma posição privilegiada dentro do conjunto das literaturas européias: "The present pre-eminence of English letters was to be secured by means of an unrivalled familiarity with, and appropriation of, the achievements of classical literature. In that way the strengths of the ancient Greeks and Romans could be made our own". Ademais, David Womersley sugere, em sua introdução à coletânea Augustan Critical Writings, que a relação dos artistas e da crítica estava abertamente ligada às instituições políticas - os elementos "augustanos" ecoariam, assim, o ponto de vista do partido Tory no que se refere à construção de uma certa imagem da literatura nacional.
}

\footnotetext{
${ }^{51}$ Ver BENJAMIN, Walter. "The Author as Producer", in: Understanding Brecht, London: Verso, 1992. pp. 85-103: "Before I ask: what is a work's position vis-à-vis the production relations of its time, I should like to ask: what is its position within them?" [Antes de perguntar: qual é a posição desta obra diante das relações de produção de seu tempo, eu gostaria de perguntar: qual é a sua posição dentro delas?] ( p. 87).
} 
exagero imaginar que a autora tivesse, em certa medida, consciência de que o livro era um produto com valor de mercado... Mas não qualquer livro, nem qualquer história. $\mathrm{O}$ romance à la Richardson já tinha dado provas de sua "rentabilidade" e o sucesso de Henry Fielding indicava que suas produções no âmbito do romance seguiriam o mesmo caminho. Sarah Fielding pode ter compreendido - como muitos outros autores da mesma época - o interesse "pecuniário" na reprodução destas formas em seu romance.

Independentemente do grau de consciência da autora a este respeito, fica talvez mais aparente o lugar ocupado por sua narrativa dentro da dinâmica de oferta e procura de romances da qual faziam parte - de maneira central em meados do século XVIII Henry Fielding e Samuel Richardson. Talvez fique mais clara também a influência que este lugar pode ter tido sobre as escolhas temáticas e formais da escritora. Malcolm Kelsall indica assim, ainda que por vias insuspeitadas, a importância de termos consciência do papel das relações materiais no processo de tratamento "técnico" da obra por parte do autor. Isto posto, tudo indica que há empréstimo no caso de David Simple. Mas de que tipo?

Identificamos na estrutura do romance elementos que repercutem as técnicas utilizadas por Richardson e Fielding, como os próprios apontaram - e como Kelsall confirmou (ainda que negativamente) em seus comentários. Ou seja: é dado que Sarah Fielding tomou "emprestadas" as lentes formais de que fizeram uso seus modelos. Do mesmo modo, o universo dos três romancistas parecia o mesmo (Inglaterra, Londres, década de 1740), o que torna ainda mais plausível a idéia do empréstimo direto. Porém, observando com mais cuidado, notamos certas diferenças que podem ter conduzido a soluções originais na fatura, as quais talvez tenham merecido pouca atenção por parte das análises críticas disponíveis acerca de David Simple ${ }^{52}$.

De início, existe o problema da posição social de Sarah. Por ser mulher solteira e remediada, ela observava o mundo que compartilhava com Henry Fielding e com Richardson sob uma perspectiva quase periférica em relação ao centro da vida política,

\footnotetext{
${ }^{52} \mathrm{O}$ ponto de vista adotado aqui foi inspirado pelo ensaio de "De Cortiço a Cortiço", de Antonio Candido, publicado em O Discurso e a Cidade (São Paulo/Rio de Janeiro: Livraria Duas Cidades/Ouro sobre Azul, 2004).
} 
social, econômica. O fato de se encontrarem justamente em posição dominante contribuiu para que os dois romancistas formalizassem os conflitos daquele mundo conforme pontos de vista que, de certa forma, disputavam a hegemonia.

Enquanto isso, a autora de David Simple teve de elaborar seu "mundo ficcional" a partir, de um lado, das influências destes paradigmas e, de outro, das condições particulares que a "realidade natural e social imediata" adquiria a partir da perspectiva do dominado. Neste sentido, o romance de Sarah Fielding "filtra o meio" a partir das exigências materiais que a posição social da autora impunha - ou seja, a partir desta perspectiva enviesada que sua situação determinava.

É da combinação destes elementos - a experiência individual da autora, sua situação social dentro daquele momento histórico preciso, o tipo de recorte conteudístico efetuado e o modo como as "lentes" se adaptaram a estas especificidades - que resulta uma organização precisa do material. Já discutimos as particularidades da situação social e financeira de Sarah Fielding, e seus efeitos nas escolhas pessoais e "profissionais" da autora. Para compreendermos de que modo ela se serviu das técnicas tomadas a $\mathrm{H}$. Fielding e Richardson, precisamos definir em maior detalhe os tipos de lente com que lidou, para em seguida procurar identificar, a partir da leitura cerrada, seus resultados.

Os comentários de Malcolm Kelsall têm pequena contribuição a oferecer para a discussão a respeito do tipo de "lentes formais" emprestadas por Sarah Fielding, assim como dos matizes que tais formas adquiriram em David Simple. A visada normativa e anistórica do crítico é, de fato, pouco esclarecedora a este respeito e se limita a uma avaliação valorativa e discutível do romance. Mais vale retornar às pistas lançadas por $\mathrm{H}$. Fielding e Samuel Richardson, partindo, porém, de uma perspectiva que, ainda dentro do âmbito da crítica anglo-saxã, pode oferecer elementos bem mais valiosos para uma entrada na matéria.

Em seu estudo A Ascensão do Romance (1957), Ian Watt observa o processo de estabelecimento do gênero sob uma perspectiva que ressalta a estreita relação entre processo social e forma literária. Watt parte do pressuposto segundo o qual o romance moderno inglês, como forma literária nova, iniciou-se com Daniel Defoe, Henry Fielding 
e Samuel Richardson. Seus comentários acerca da produção dos três autores se organizam a partir de uma observação aguda das mudanças pelas quais passava a sociedade inglesa naquele momento - como o desenvolvimento crescente do capitalismo, o aumento considerável do público leitor, o movimento de secularização da ética protestante, a ênfase na experiência individual.

Assumindo este ponto de vista, Watt redefine o "realismo formal" como a característica que se encontra no cerne da novidade do gênero - tal como este começa a se desenvolver a partir do início do século XVIII na Inglaterra -, não tanto por representar um recorte específico da realidade, mas principalmente na medida em que propõe um câmbio na maneira como a vida é representada. Assim, o realismo de Defoe, Fielding e Richardson se traduziria através do inusitado tratamento formal dado à decupagem da realidade que estes autores se propuseram a efetuar, contrariando os modelos literários clássicos e enfrentando a má reputação que o gênero carregava.

Um dos marcos desta mudança de enfoque na seleção e no tratamento do material reside justamente na noção de indivíduo. Watt explica como o debate filosófico - com Descartes, mas especialmente com Locke, na Inglaterra - sistematizou a idéia da apreensão individual da realidade, o que tornou mais complexa a tarefa do romancista. As narrativas ficcionais passam assim a dar importância ao que há de particular na experiência humana - pessoas particulares em situações particulares, ao invés de tipos gerais transitando num cenário previamente sugerido pela tradição. Watt observa que Richardson encontrou uma solução fundamental para esta questão ao evitar o enredo "tradicional" e adotar o esquema de cartas. Richardson formaliza de modo particularmente bem-sucedido questões centrais do que já se poderia identificar como a tal experiência íntima - ou, dito de outra forma, o conflito entre o indivíduo e a sociedade.

Parece ser Clarissa o ponto alto do amadurecimento de Richardson neste sentido. Os comentários de Watt a respeito deste romance indicam a harmonização entre o aparato formal do autor e a problemática tratada: 
Clarissa e Lovelace dependem um do outro tão completa e fatalmente quanto Tristão e Isolda ou Romeu e Julieta; contudo, de acordo com a visão subjetiva do romance, as barreiras que de fato impedem a união dos pobres amantes são subjetivas e, em parte, inconscientes; o destino atua no indivíduo através de várias forças psicológicas que, sem dúvida, são públicas e sociais, pois as diferenças entre os protagonistas representam conflitos maiores de atitude e ética em sua sociedade, mas também são tão completamente interiorizadas que o conflito se expressa como uma luta entre personalidades e até entre partes diferentes da mesma personalidade ${ }^{53}$.

Assim, o trunfo de Richardson reside no modo como o romancista expõe, através do subjetivo embate de "vontades", na mais sutil expressão de pontos de vista pessoais, conflitos que relevam das relações que se estabelecem na vida pública - relações de classe social, de posição, de ética, num momento em que estas relações e os valores em jogo estavam em busca de reacomodação. A interiorização profunda destas questões dá notícia das ambigüidades a que já estavam sujeitos os homens e mulheres dos meados do século XVIII na Inglaterra.

No que se refere ao autor de Tom Jones, Watt explica, de antemão, não poder afirmar "que Fielding tenha contribuido tão diretamente quanto Richardson para o surgimento do romance ${ }^{, 54}$. O crítico considera que os elementos que caracterizam sua prosa têm suas origens muito mais fundamentadas na tradição clássica do que no processo de mudança social. Apesar de ter consciência de que Fielding deu pouca atenção à idéia de propor uma teoria completa da ficção, Watt parece levar a sério demais a discussão sobre o "poema épico em prosa" e os posicionamentos públicos do autor a respeito da relação entre a tradição clássica e o "novo" romance. Esta nuance na análise de Watt conduz, de certo modo, a que sejam por vezes subestimadas as tensões e as disparidades entre as intenções do romancista e o que de fato se apresenta em suas narrativas.

Ainda assim, os comentários de Watt apontam caminhos importantes para a reflexão sobre o funcionamento da prosa de Henry Fielding dentro da perspectiva que

\footnotetext{
${ }^{53}$ WATT, Ian. op. cit., p. 206-207.

${ }^{54}$ WATT, Ian. op. cit., p. 208.
} 
inclui sua relação com o processo social. Para o crítico, enquanto Richardson rejeitara os modelos dados pela poética tradicional, o autor de Henry Fielding "estava mergulhado" nestas e procurou abertamente vincular a elas suas produções. $\mathrm{O}$ vínculo com $\mathrm{o}$ classicismo se traduz essencialmente, para Watt, na elaboração do enredo e no foco narrativo, assim como na construção dos personagens. A variedade de tipos sociais circulando numa trama repleta de peripécias serve a expor os mecanismos de uma ordem universal maior, para a qual os pequenos dramas individuais são irrelevantes. Este "notável controle sobre uma estrutura muito complexa" revela, para o crítico, um provável posicionamento de classe de Henry Fielding - que, pertencente à pequena fidalguia, "recorta" o mundo com uma visada bem mais conservadora e estática do que seus companheiros.

A estabilidade das posições sociais ganha, assim, maior espaço dentro da estrutura de seus romances, em detrimento de qualquer preocupação no desenvolvimento da profundidade psicológica nos personagens ou da explicitação de um conflito claro entre valores individuais e sociais - o que, além do mais, poderia insinuar uma certa falta de decoro... Este posicionamento explica também, de certo modo, a presença de um narrador "intruso" e muitas vezes irônico que se apresenta, sem disfarces, como o grande mediador entre o universo narrado e o leitor.

A ironia que atinge inclusive as classes dominantes não deve, no entanto, nos enganar. Mais do que comentário subversivo, ela serve como "tributo à firmeza de sua convicção no tocante à premissa de classe ${ }^{„ 55}$, já que é esta que desencadeia as diferentes peripécias enfrentadas, por exemplo, por seu personagem de grande sucesso, Tom Jones. A busca e o reencontro do herói com suas verdadeiras - e nobres - origens são o que coloca o enredo em marcha, e nunca a transgressão da ordem social.

Watt faz rápida referência a David Simple quando discute a entrada da experiência urbana - leia-se londrina - na prosa dos três autores que se propõe a estudar. Veremos adiante em que medida seus comentários alimentam um viés analítico do romance de Sarah F. que o crítico deixou escapar em função do recorte que escolheu para

${ }^{55}$ WATT, Ian. op. cit., pp. 234-235. 
seu trabalho ${ }^{56}$. De todo modo, a partir dos comentários de Watt, duas perspectivas mais palpáveis se configuram. Estas nos permitem voltar às Adventures of David Simple com o olhar mais avisado. Encontramos os elementos assinalados por Watt na prosa de Sarah Fielding? Quais são as primeiras impressões do leitor quanto ao modo como são desenvolvidos?

Aparece já no primeiro capítulo de David Simple um narrador que anuncia seu plano: vai contar em segunda mão a história de David (depois de tê-la ouvido do próprio): "this History is taken from his own Mouth" (DS, 10). Seguindo a convenção já tradicional nos diferentes subgêneros de romance na Inglaterra setecentista, aparece na seqüência a apresentação das origens do herói e de sua posição no mundo:

Mr. David Simple was the eldest Son of Mr. Daniel Simple, a Mercer on Ludgate-hill. His Mother was a downright Country Woman, who originally got her living by Plain-Work; but being handsome, was liked by Mr. Simple. When, or where this Couple met, or what happened to them during their Courtship, is foreign to my present Purpose, nor do I really know. But they were married, and lived many Years together, a very honest and industrious life; to which it was owning, that they were able to provide very well for their children. They had two Sons, David and Daniel, who, as soon as capable of learning, were sent to a publick School, and kept there in a manner which put them on a level with Boys of a superior Degree, and they were respected equally with those born in the highest Station ${ }^{57}$. (DS, 9)

David não é filho de aristocratas; nem poderia ser visto como parte da gentry. O pai é comerciante de tecidos finos em Ludgate-hill ${ }^{58}$, enquanto a mãe, moça do campo,

\footnotetext{
${ }^{56}$ Como veremos adiante, Watt se refere a David Simple no contexto da ligação entre urbanização e a concentração do romance nas relações pessoais. Ver WATT, Ian. op. cit., p. 161-162.

${ }^{57}$ [O Sr. David Simple era o filho mais velho de Sr. Daniel Simple, um comerciante de tecidos em Ludgatehill. Sua mãe era uma camponesa que originalmente ganhara seu sustento com trabalho; mas, sendo bonita, havia agradado ao Sr. Simple. Quando, ou onde este casal se encontrou, ou o que aconteceu durante seu namoro, não sei, e não interessa para meu propósito neste momento. Mas eles se casaram, e viveram muitos anos juntos, uma vida honesta e laboriosa; do que se deduz que puderam oferecer boas condições de vida a seus filhos. Tiveram dois filhos, David e Daniel, os quais, assim que se tornaram capazes de aprender, foram enviados para uma escola particular na qual foram mantidos no mesmo nível de garotos de status superior, e eram igualmente respeitados como aqueles nascidos em famílias de nível social mais elevado.]

${ }^{58}$ Em Ludgate-hill encontravam-se as lojas de tecidos elegantes na Londres de meados do século XVIII. O periódico The Female Tatler, publicado na mesma época do Tatler, de Addison e Steele, relata uma visita da suposta autora (provavelmente um personagem), Mrs. Crackenthrope - "a Lady that knows every thing"
} 
chegou a ganhar seu sustento através do trabalho. Porém, as circunstâncias que levaram a esta união pouco interessam ao narrador ("is foreign to my present Purpose"). Tanto é assim que os anos que encerram a história do casal e a infância dos filhos são relatados em duas breves linhas. O que interessa informar ao leitor é o esforço no trabalho e a prosperidade do comércio do pai, que fizeram com que David e Daniel fossem elevados a um nível social superior e freqüentassem a mesma escola que os filhos das classes dominantes ${ }^{59}$.

A ênfase na "industrious Life" dos pais de David coloca na dianteira da narrativa a força dos valores puritanos, secularizados. Lembra também que, na Inglaterra - muito mais do que no continente -, a estreita relação entre a ética religiosa e o trabalho era, de fato, material de primeira ordem para o romance em formação. $O$ interesse neste dado se justifica ainda, dentro da lógica do romance, pelo fato de que a fortuna do pai se encontra na origem do primeiro "nó" narrativo, que vai resultar no afastamento de David da casa do irmão e no início de sua busca.

O narrador não tem intenções de se esconder do leitor - muito pelo contrário. Explica o ritmo que pretende dar à história - "whoever thinks proper to read the next Chapter, may know", ou ainda, "I must pause a while before I can relate it"60 -, escolhendo os momentos de ruptura e retomada da narrativa. Assim, quando David pede abrigo na casa do tio (depois de ter sido praticamente deserdado por Daniel), encontramos a seguinte afirmação no fim do capítulo:

\footnotetext{
- às lojas de Ludgate-hill: "This afternoon, some ladies, having an opinion of my fancy in clothes, desir'd me to accompany 'em to Ludgate-Hill, which I take to be as agreeable an amusement as a lady can pass away three or four hours in; the shops are perfect gilded theatres." [Esta tarde, algumas senhoras que têm uma certa opinião sobre meu gosto em roupas, desejaram que eu as acompanhasse a Ludgate-Hill, tarefa que eu acredito ser bastante agradável como distração para uma senhora durante três ou quatro horas; as lojas são verdadeiros teatros dourados.] In: Female Tatler, no. 9. Fonte: http://www.wwnorton.com/nael/18century/topic 1/shops.htm. Acessado em 27/06/2005.

59 As "publick schools", apesar do nome, eram escolas particulares, freqüentadas pelos filhos das classes mais abastadas.

${ }^{60}$ [quem acreditar que deve ler o próximo capítulo saberá]; [devo fazer uma pausa antes de contar isto]
} 
And there [na casa do tio] for some time I will leave him [David] to his own private Sufferings, lest it should be thought I am so ignorant of the World, as not to know the proper Time of forsaking People61. (DS, 20)

Do mesmo modo, quando conta em mais detalhe a rotina e as motivações “criminosas" de Peggy e John, casal de criados que auxiliou Daniel em seu plano cruel contra David, o narrador se reapresenta abertamente para explicar por que motivo evitará o relato exato das brigas do casal:

(...) for, as I hope to be read by the polite World, I would avoid every thing, of which they can have no Idea ${ }^{62}$. (DS, 21)

O narrador escolhe aqui o seu público leitor e expõe abertamente o fato de que efetua um recorte da realidade - algumas coisas serão contadas, outras não, por decisão exclusivamente sua. Tem o cuidado de sempre deixar claro quem é o condutor da narrativa, e não hesita em se intrometer se for necessário. Mas a semelhança com a prosa de H. Fielding se acentua para além da presença marcante do narrador. Quando as "viagens londrinas" de David se iniciam, o leitor tem diante de si o desenrolar de um enredo bastante recheado. No capítulo 4 (Livro 1), David faz sua primeira parada na Bolsa de Valores:

(...) The first place he [David] went to, was the Royal-Exchange. He had been there before, to see the Building and hear the Jargon at the time of high Change; but now his Curiosity was quite of a different kind. He could not have gone any where to have seen a more melancholy Prospect, or with more likelihood of being disappointed of his Design, than where Men of all Ages and all Nations were assembled, with no other View than to barter for Interest. The Countenances of most of the People, showed they were filled with anxiety: Some indeed appeared pleased; but yet it was with a mixture of fear63. (DS, 28)

\footnotetext{
${ }^{61}$ [E ali o deixo por algum tempo, com seus sofrimentos íntimos, para que não se pense que sou tão ignorante sobre o mundo a ponto de não saber o momento certo de deixar as pessoas em paz.]

${ }^{62}$ [Como espero ser lido(a?) pelo mundo educado, eu evitaria tudo aquilo de que eles não têm idéia.]

${ }^{63}$ [O primeiro lugar ao qual ele se dirigiu foi a Bolsa de Valores. Ele já havia estado ali antes, para ver o edifício e escutar o jargão na época de câmbio alto; mas agora sua curiosidade era diferente. Ele não poderia ter ido a nenhum outro lugar para ver uma cena mais melancólica, ou com maior probabilidade de
} 
É interessante notar o interesse que tal lugar já havia adquirido na vida de uma cidade como Londres, a ponto de entrar como primeiro cenário para as flâneries de David. Vale notar também o caráter cosmopolita do lugar - "Men of all Ages and all Nations" -, misturado a uma espécie de melancolia, ao medo e à ansiedade. O mundo da especulação no pós-South Sea Bubble ainda podia ser atraente, mas carregava em si a marca da derrota de $1720 \ldots$

No capítulo 8 do mesmo livro, David passeia pela Strand:

As David was one day walking along the Strand, full of these Reflections, he met a Man with so contented a Countenance, he could not forbear having a Curiosity to know who he was: he therefore watched him home; and, on Enquiry, found he was a Carpenter, who work'd very hard $(\ldots)^{64} .(\mathrm{DS}, 50)$

A rua é o local onde David pode observar diferentes tipos sociais, sem compromisso. Seguindo um ou outro personagem que identifica em suas andanças, o herói coloca o leitor em contato com os tipos sociais que já compunham, nestes meados de século XVIII, a diversidade da metrópole. Além do carpinteiro da Strand, David segue a trilha de um "rich Jew" - e quase se casa com a filha deste -, de três irmãs que perdem a compostura por causa da herança paterna, de um cavalheiro chamado Mr. Orgueil, de outro que respondia pelo nome de Mr. Spatter.

O esquema episódico se organiza, assim, através da passagem do herói por diferentes pontos da cidade, seja acompanhado por estes personagens, seja sozinho - da Bolsa de Valores à Strand, mas também Fleetstreet (onde já se concentrava a imprensa: o primeiro jornal londrino, 'The Daily Courant', saiu ali em 1702), Pall Mall (rua célebre

se desapontar em seu objetivo, do que num lugar no qual homens de todas as idades e de todas as nações estavam reunidos com o único fim de fazer escambo por puro interesse. Os semblantes da maioria das pessoas mostravam que elas estavam ansiosas. Algumas pareciam felizes, mas ainda assim, com um misto de temor.]

${ }^{64}$ [David estava um dia andando pela Strand, metido em suas reflexões, quando encontrou um homem com feição tão satisfeita, que ele não pôde controlar a curiosidade de saber quem era: ele então seguiu-o até sua casa; e, depois de investigar, descobriu que se tratava de um carpinteiro que trabalhava muito (...).] 
pelos clubes e coffeeshops onde os homens se reuniam), Covent Garden, o teatro, casas onde se joga whist ${ }^{65}$, onde se organizam conversations, ou onde David conhece a vida em condições talvez superiores e às vezes bastante inferiores às suas. O herói transita tranquilamente por estes espaços e meios sociais, sem que sua presença cause qualquer tipo de rejeição ou estranhamento.

No segundo livro, no entanto, o romance entra num ritmo bastante diverso. A história de Cynthia interrompe a narrativa peripatética e se estende por três capítulos $(6,7$ e 8), a ponto de fazer o leitor se esquecer levemente do que o narrador havia anunciado no início. Nestes capítulos, é o personagem que toma a palavra e o narrador praticamente se apaga. Tudo que o leitor aprende sobre a moça vem - desta vez realmente - de sua "própria boca".

Ao invés das impressões de David acerca do mundo e das pessoas através da mediação do narrador, temos de primeira mão os sentimentos e angústias do personagem. David se coloca na mesma posição do leitor - como "ouvinte" silencioso - e Cynthia toma as rédeas do romance. Ao expor o drama pessoal deste personagem em primeira pessoa, Sarah Fielding desenvolve, à moda de Richardson, os efeitos que opera, no indivíduo, a interiorização de questões que relevam de uma situação socioeconômica que ultrapassa o âmbito pessoal.

Cynthia, de fato, se vê encurralada numa condição pela qual é apenas em parte responsável, pois perdeu a proteção de sua família e vive às custas da boa vontade alheia. Assim é que não estranhamos quando ela explica seus sentimentos durante uma viagem à França como acompanhante - e dependente - de Lady -------.:

I was now in the place of the World I had often most wished to go to, where I had every thing in great plenty, and yet I was more miserable than ever. Perhaps you will wonder what caused my Unhappiness; but I was to appear in a Character I could not bear, namely, that of a Toad-eater: and what hurt me most,

\footnotetext{
${ }^{65}$ Jogo de cartas inventado na Inglaterra no século XVIII e para o qual foi escrito um livro de regras em 1742 .
} 
was that my Lady herself soon began to take pains to throw me into it as much as possible ${ }^{66}$. (DS, 113)

Do mesmo modo, sentimos grande envolvimento com a história da moça quando ela relata o momento em que é acusada de tentar seduzir o jovem sobrinho de Lady

My Lady ----- has a Nephew of about seventeen Years of Age, who after the Death of his Father, will be Earl of --------, with a great Estate. This young Man took such a Fancy to me, that the very first Opportunity he had of speaking to me alone, he made me a Proposal of Marriage. (...) I was, at first, so surprized, I knew not what to answer; but soon as I could recollect my Thoughts, and revolve in my Mind the Situation I was in, I told him I was infinitely obliged to him, for his good Opinion of me; but that as I lived in my Lady -------'s House, I should think myself guilty of the utmost Treachery, to marry so near a Relation of her's without her Consent; and as in my Circumstances I was not likely to obtain that, I begged him to give up all Thoughts of it. The more I refused him, the more earnest he was with me to comply: But while we were talking, my Lady entered the Room. I could not help blushing and looking confused, and my Lord - was almost as much so as myself ${ }^{67}$. (DS, 118-119)

As injustiças de que Cynthia parece padecer fazem, como vimos, com que a moça decida partir de Londres. O romance retoma em seguida o ritmo anterior: "My Hero had now left Varnish, and Cynthia was gone out of Town; so that he was to begin the World

\footnotetext{
${ }^{66}$ [Eu estava no lugar que mais tinha desejado visitar no mundo inteiro, onde eu tinha tudo em grande quantidade, e ainda assim estava mais infeliz do que nunca. Talvez você imagine o que causou a minha infelicidade; eu precisava cumprir um papel que não suportava, o de "engolidora de sapos": e o que me magoou mais foi o fato de a própria Lady ter se esforçado ao máximo para me colocar nesta situação.]

${ }^{67}$ [Minha Lady --------- tem um sobrinho de dezessete anos que, depois da morte de seu pai, será Conde de -------, com uma grande propriedade. Este jovem se apaixonou por mim de tal forma que, na primeira oportunidade a sós comigo, pediu minha mão em casamento. (...) De início, eu fiquei tão surpresa que não sabia o que responder; mas aos poucos fui recompondo meus pensamentos, revirando em minha cabeça a situação em que estava, e disse a ele que estava muito agradecida por sua opinião tão positiva sobre a minha pessoa; mas que eu vivia na casa de Lady --------- e que me sentiria culpada da mais alta traição se me casasse com uma pessoa relacionada de modo tão próximo a ela, sem seu consentimento; e como, devido à minhas circunstâncias, eu não o teria, implorei que ele desistisse daqueles pensamentos. Quanto mais eu recusava, mais ele insistia para que eu aceitasse: Mas enquanto falávamos, minha Lady entrou na sala. Eu não pude evitar enrubescer, e meu Lorde ---------- tanto quanto eu.]
} 
again" (DS, 125) ${ }^{68}$. Mas logo voltamos à perspectiva dramática, com a entrada no enredo de Camilla e Valentine, neste mesmo capítulo. Depois de uma breve apresentação das circunstâncias em que viviam os dois irmãos, inicia-se uma outra série de três capítulos em modo "dramático", nos quais Camilla relata sua história.

Aprendemos então as circunstâncias especialmente cruéis da morte de sua mãe e do casamento do pai com Lívia, uma futura madrasta bastante suspeita. A relação com esta última aparece, aqui, sob o viés específico da experiência individual da moça:

Poor Valentine and I walked about the House forlorn and neglected; what I felt (and I dare assert the same of him, at the Alteration in our Father's behaviour) I shall no attempt to describe, as I am very certain no Words can express it so strongly as your own Imagination will suggest it to you ${ }^{69}$. (DS, 149)

Depois de ser agredida fisicamente pelo pai - que tomara as dores da esposa em mais uma briga entre esta e a filha -, Camilla relata sua decisão de deixar a casa da família:

Oh! Valentine, in this House I can live no longer; the Sight of my Father, now I have such evident Proofs his Affection is so entirely alienated from me, is become a great Torment to me as ever it was a Blessing. (...) But then, how shall I leave you!70 (DS, 158)

O leitor ainda tem tempo suficiente para derramar algumas lágrimas, com Camilla e Valentine acusados de incesto, ou ainda com a moça disfarçada de pedinte - única solução encontrada para sua subsistência - e expulsa da rua onde pedia esmola por oferecer "concorrência" aos pedintes mais antigos... A narrativa logo retoma seu ritmo

\footnotetext{
${ }^{68}$ [Meu herói agora tinha deixado Varnish, e Cynthia havia deixado a cidade; logo, ele deveria lançar-se novamente no mundo.]

69 [O pobre Valentine e eu andávamos pela casa, tristonhos e negligenciados; o que eu senti (e ouso afirmar o mesmo por ele, com a alteração no comportamento de nosso pai) não posso tentar descrever, pois acredito não ter palavras para expressá-lo tão fortemente como sua imaginação sugerirá a você.]

${ }^{70}$ [Oh! Valentine, nesta casa eu não posso mais viver; a visão de meu pai, agora que tenho provas evidentes de que perdi inteiramente seu afeto, tornou-se um grande tormento, quando antes era uma benção. (...) Mas como deixar você!]
} 
episódico - "David shook with Horror at that Thought" -, e o herói volta a ser o fio condutor do enredo. Mais adiante, no entanto - nos dois últimos capítulos (8 e 9) deste mesmo livro -, nos deparamos novamente com uma história pessoal. É Isabelle, a francesa, que abre seu coração para os quatro amigos.

A moça relata desta forma os sentimentos que experimentou diante da perspectiva de um casamento arranjado por seu pai:

For my own part, I neither liked nor disliked the Gentleman, but was perfectly averse to Marriage, unless I had a tender Regard for the Man I was to live with as a Husband. (... $)^{71}$. (DS, 197-198)

Das três histórias de vida narradas ao longo de uma série contínua de capítulos, a de Isabelle é a que mais carrega uma semente de tragédia. A seqüência de triângulos amorosos em que a moça é sempre o pivô - primeiro com sua amiga Julie e Monsieur Le Buisson; depois, com sua cunhada Dorimene e o Chevalier Dumont - termina muito mal, e ela não vê outra saída a não ser a clausura, "a religious Life being the only Relief to such Sorrows as mine" 72 (DS, 249).

O relato de Isabelle também é o que perturba mais o leitor, já que o personagem aparece, conta sua história e desaparece sem deixar rastros no resto do romance, ao contrário de Cynthia e Camilla, que ficam ao lado de David até o Volume the Last. Não é preciso muita imaginação para identificar, em Isabelle, um lastro de romanesco que a França talvez representasse no imaginário inglês - marqueses, chevaliers, paixões intensíssimas e, como sempre, um convento, dando notícia de um mundo ainda bastante marcado pela força da aristocracia e da Igreja Católica. Esta pitada de exotismo parecia de fato ter mantido seu poder de sedução...

No entanto, existem diferenças importantes na construção deste personagem que acabam por inviabilizá-la como típica heroína do romanesco - ou mesmo como pivô de

\footnotetext{
${ }^{71}$ [De minha parte, eu não gostava nem desgostava daquele cavalheiro, mas era totalmente contrária ao casamento, a não ser que tivesse afeto pelo homem com quem viveria como marido. (...)]

${ }^{72}$ [uma vida religiosa é o único alento para sofrimentos como os meus]
} 
tragédia à francesa. Procuraremos apontar, mais adiante, elementos que ajudem a dar mais sentido à presença da narrativa pessoal de Isabelle dentro do conjunto do romance a fim de dispersar, quem sabe, a má impressão que fica deste episódio um tanto "descolado" do resto.

De todo modo, David e seus amigos só retomam o périplo no terceiro capítulo do livro quatro, quando decidem subir o rio. O contato com a natureza, "the Water, 'ever Friend to Thought',", o barulho dos remos, a mudança de ambiente acabam favorecendo a conversação. Entram a falar no assunto que mais lhes interessa, a saber, "human Miseries, most of which arise from the Envy and Malignity of Mankind"73 (DS, 251). O passeio ainda serve de pretexto para novas observações de cenas da vida da cidade, desta vez em sua versão ribeirinha: uma corrida de barcos serve para lançar o assunto da competição entre os homens; a parada numa casa (depois de terem sido molhados pela passagem de um barco em "alta velocidade") os faz encontrar uma mulher maltratada pelo marido; Cynthia aproveita também para contar alguns casos de suas viagens como acompanhante de Lady ------.

A primeira parte de David Simple termina com o narrador dando as últimas notícias - "From thence they [David, Camilla, Valentine e Cynthia] proceeded to Church, where the Ceremony [os casamentos] was performed". O narrador ainda toma a liberdade de tirar suas lições e de expor, de quebra, suas opiniões sobre sua função e sobre o romance em geral:

Perhaps it may be here expected I should give some Description of the Persons of my favorite Characters; but as the Writers of Novels and Romances have already exhausted all the Beauties of Nature to adorn their Heroes and Heroines, I shall leave it to my Readers Imagination to form them as just they like best $(\ldots)^{74}$. (DS, 303)

Vimos, portanto, como o ponto de vista reverbera este ritmo imposto ao enredo pela troca de registro - episódico, dramático, novamente episódico. O foco varia

\footnotetext{
${ }^{73}$ [as misérias humanas, muitas das quais são resultado da inveja e da maldade da humanidade]

${ }^{74}$ [Talvez aqui exista a expectativa de que eu descreva as pessoas de meus personagens favoritos; mas como os escritores de romances e histórias romanescas já usaram todas as belezas da natureza para enfeitar seus heróis e heroínas, deixarei que a imaginação dos meus leitores faça deles o que achar melhor (...).]
} 
constantemente entre a "grande angular", expressa pela voz do narrador que tudo vê e seleciona nos capítulos episódicos, e o "primeiro plano" dos momentos dramáticos, nos quais o olhar do leitor é direcionado para perto, bem perto de cada uma das três mulheres.

A ironia do narrador, ausente nos capítulos "dramáticos", chega muitas vezes a ser mordaz nos episódios de rua, nas cenas de encontros fortuitos, nas conversações em casas de famílias ricas. Deste modo, assistimos junto com David, no capítulo 2 do livro segundo, a uma conversa na casa de uma mulher com notória reputação de "sábia". Falase de arte e artistas:

Here the whole Company fell into a violent Fit of Laughter, and the Word ridiculous was the only Sound heard for some time; and then fell back again to their Discourse on Authors, in which they were all so desirous to prove their own Judgment, that they would not give one another leave to speak ${ }^{75}$. (DS, 85)

Seguindo o mesmo princípio, nos capítulos em que são relatadas as "aventuras" de David, encontram-se personagens típicos, que muitas vezes não têm nome - como o "rich Jew" (DS, 32), ou as "three Daughters" (DS, 46) - ou que recebem nomes quase alegóricos, como Mr. Varnish ou Mr. Orgueil ${ }^{76}$. Os dois últimos - assim como Mr. Spatter - aparecem no caminho de David com a função de servir como ocasião para alguma discussão de cunho moral (acerca do comportamento alheio), ou como "guias" que facilitam a entrada do protagonista num universo específico da vida da capital - Mr. Spatter conduz o rapaz a uma "conversation" na casa de uma senhora rica e cultivada (DS, 82), enquanto Mr. Orgueil acompanha David ao teatro (DS, 67).

\footnotetext{
${ }^{75}$ [Aqui, o grupo todo caiu na gargalhada, e a palavra ridiculo foi o único som que se ouviu durante algum tempo; depois, eles voltaram à conversa sobre autores, na qual tinham tanta vontade de provar a própria opinião que um não deixava o outro falar.]

${ }^{76}$ Estes personagens típicos têm nomes que às vezes servem para identificar sua característica principal. "Orgueil" é o termo francês para "orgulho", e "varnish" em inglês quer dizer "verniz", ou "envernizar". David se decepciona com os dois - Mr Orgueil e Mr Varnish - pelo comportamento esnobe que demonstram...
} 
Tomemos um destes personagens para observarmos melhor como a caracterização, nos capítulos episódicos, se diferencia dos capítulos de tom dramático. Quando Mr. Orgueil aparece na vida de David, eis o que o leitor aprende sobre ele:

He had something in his Manner, which seemed to declare that inward Serenity of Mind, which arises from a Consciousness of doing well, and every Trifle appeared to give him pleasure, because he had no Tumults within to disturb his Happiness. His sentiments were all so refined, and his Thoughts so delicate, that David imagined such a Companion, if he was not again deceived in his Opinion, would be the greatest Blessing this World could afford ${ }^{77}$. (DS, 57)

Conhecemos aqui mais sobre o narrador - e sobre o tipo de narrativa que este quer colocar em movimento - do que sobre o personagem. Na seqüência, vemos Mr. Orgueil apresentar a David o que o narrador chama de "many various Characters" (DS, 67). Conta uma série de episódios da vida de quatro homens que os dois haviam encontrado na véspera, numa taverna, e dá sua opinião. Em tom de crítica, ele avisa que David se decepcionará: "your Goodness will make you sigh at what I am going to relate" 78 (DS, $58)$.

O termo "characters" está no lugar adequado. Lembra a tal tradição clássica que vinha desde Teofrasto, e que Henry Fielding faz questão de reiterar em suas observações acerca da construção do personagem. Nada de singularidades: o que interessa ao romancista é representar tipos no que estes têm de particular - com leves pitadas de "detalhes humanos" para garantir o efeito de verossimilhança. Nada que se assemelhe ao discurso de Cynthia, Camilla e Isabelle.

Diante deste breve percurso pela primeira parte do romance, parece bastante evidente que Sarah Fielding reconhecia e dominava as técnicas que procurou emprestar de seu irmão e de seu amigo. Tanto o tratamento episódico, o narrador intruso, os personagens típicos, quanto a expressão da individualidade dos três personagens

\footnotetext{
${ }^{77}$ [Ele tinha algo em sua maneira de ser que parecia declarar uma serenidade interna, que se origina na consciência de fazer o bem, e qualquer coisa parecia lhe dar prazer, pois ele não tinha tumultos internos para perturbar sua felicidade. Seus sentimentos eram todos tão refinados e seus pensamentos tão delicados que David imaginou que tal companheiro, se não o decepcionasse, seria a maior bênção que o mundo poderia lhe oferecer.]

${ }^{78}$ [Sua bondade o fará suspirar quando ouvir o que eu tenho para contar.]
} 
femininos se desenvolvem de forma a dar a entender que as "lentes formais" tiveram muito mais serventia do que pareciam indicar os comentários de Malcolm Kelsall.

Em Volume the Last, no entanto, este ritmo não se repete. A autora optou por abandonar os capítulos "dramáticos" e concentrar o fio condutor da trama na figura do narrador. São incluídos na narrativa alguns diálogos em forma de texto teatral e várias cartas; porém, é central a força do narrador como aquele que conduz, seleciona e explica a vida de David e seus amigos para o leitor. A trama é enxuta, se comparada àquela da primeira parte do romance. O narrador que centraliza tudo funciona como aquele já conhecido; mas algumas diferenças se fazem notar.

Esta diferença se evidencia, sobretudo, através de um certo toque de melancolia que aponta, possivelmente, para a radicalização na relação entre os princípios morais que dão base ao romance e as crescentes dificuldades que a realidade vinha impondo nestes nove anos que separam as duas fases da história. Assim, vemos, no primeiro capítulo desta segunda parte, um narrador que se apresenta claramente de maneira cínica em relação a seu leitor:

'That solid and lasting Happiness is not to be attained in this World.' That a frequent Repetition of this Observation is necessary, in order to remind People of its Truth, appears but too plainly, when we see that, notwithstanding the universal Concurrence of Mankind, in all Ages, in its favour, yet their Forgetfulness of it may fairly be concluded from the various and anxious Pursuits, in which they are so universally employed ${ }^{79}$. (VL, 314)

O narrador que, em David Simple, escolhia seus leitores e caminhava lado a lado com estes nas descobertas de David pela cidade de Londres, muda de registro - não confia mais. Faz sentido: a motivação da história que se segue não é mais a busca de um amigo, e sim a luta pela sobrevivência em condições cada vez mais delicadas. Isto não significa, no entanto, que o narrador tenha perdido suas características "fieldinguianas".

\footnotetext{
79 ['Que não se chega à felicidade sólida e duradoura neste mundo'; Que a repetição freqüente desta observação seja necessária para lembrar às pessoas sua veracidade, não pode ser mais óbvio quando vemos que, apesar dos esforços de toda a humanidade, em todas as épocas, nesta direção, ainda assim seu esquecimento pode ser deduzido das inúmeras tentativas nas quais se envolvem.]
} 
Quer dizer apenas que o tal "encontro da felicidade" com o qual o herói ainda sonhava na primeira parte da história cede espaço, agora, para o retrato de uma realidade bastante mais dura no que diz respeito à vida em sociedade e à batalha pela subsistência. Apesar de ainda acreditar em seus ideais, o centro do interesse de David é simplesmente oferecer aos seus um teto, alimentá-los e fechar-se, com eles, numa espécie de "mundo à parte".

É justamente a premência de encontrar dinheiro para o "leite das crianças" que impede que este projeto seja levado a cabo pelo herói e sua "little Company". A família tinha feito planos de comprar uma propriedade e instalar-se no campo a fim de fugir das agitações da vida da capital. Mas uma primeira dificuldade financeira aparece quando Valentine e Camilla perdem as dez mil libras dadas pelo pai, $M r$. $C$-----. Os Simple abandonam os planos de compra e se contentam em alugar uma casa - "with a pretty garden and all the Conveniences round it"- em Lincolnshire.

$\mathrm{Na}$ seqüência, Cynthia fica doente e o médico indica as águas de Bath. Mas acontece o inesperado: “(...) the Morning before they undertook their Journey, David received a letter from London, informing him of an Affair, which was of too much Consequence for him to Neglect" ${ }^{80}(\mathrm{VL}, 316)$. Alguém reclamava, na justiça, a fortuna do tio de David - dinheiro que havia sido, em princípio, herdado pelo herói. Este motivo um tanto burocrático tem poderoso efeito na estrutura da narrativa, e coloca em marcha novamente a seqüência das perdas e decepções de David e seu núcleo familiar.

Apesar da semelhança com o evento que proporcionou a saída de David pelo mundo - a perda inicial da fortuna do pai -, a diferença é grande no contexto geral da segunda parte do romance. Enquanto na primeira parte a perda da herança serve apenas como mote para a viagem - pois ele acaba reavendo tudo o que era seu de direito -, aqui estas perdas financeiras vão desencadear o processo inevitável da queda do herói e, conseqüentemente, dos valores que sua busca inicial representava.

O espaço do romance vai, assim, se decidindo também em função das necessidades e dos apuros financeiros da família. Se na primeira etapa da história era

\footnotetext{
${ }^{80}$ [na mesma manhã em que viajariam, David recebeu uma carta de Londres informando-o sobre um assunto cujas conseqüências eram demasiado importantes para serem negligenciadas]
} 
Londres o lugar em que tudo acontecia, observamos como as diferentes mudanças de endereço - distanciando-se da cidade - marcam a decadência de David e de seu projeto. David e seu grupo vão de Londres para Lincolshire, numa casa alugada; de Lincolnshire para uma pequena cidade chamada Heddington, onde vivem num "small neat Tenement (...) only a Mile out of the great London road"81 (VL, 319). Deste lugar, passam para uma "cottage", até que no segundo capítulo do sétimo livro de Volume the Last, vem o golpe final: um incêndio na casa de David e Camilla faz com que percam tudo. É um fazendeiro - Farmer Dusnter - que os acolhe.

Do mesmo modo, o leitor repara que a distensão do tempo que caracterizava as caminhadas de David pela metrópole não está mais presente na segunda etapa de sua história. Ao tempo ritmado pela caminhada, pela observação, pelo encontro e pela descoberta, substitui-se um tempo ligeiramente mais apressado, o tempo da resolução de dificuldades. O abandono dos capítulos "dramáticos" contribui da mesma forma para que Volume the Last seja mais sucinto do que o primeiro David Simple, além de indicar fortemente a mudança nas prioridades da autora em relação à primeira parte da história.

A construção dos personagens segue o mesmo movimento. No lugar dos encontros variados que davam pinceladas de traços da vida londrina, encontramos nesta segunda fase da narrativa da David um grupo reduzido de personagens que correspondem à pequena sociedade com a qual o herói e sua família ainda convivem. Forçosamente, a construção destes personagens se aprofunda: conhecemos melhor Mr. Orgueil - e sua orgulhosa esposa -, além de Mr. e Mrs. Ratcliff, Farmer Dunster e Mrs. Dunster.

Mas a caracterização não retoma os elementos do drama. Antes, ecoa o que já havia sido apresentado nos capítulos "episódicos" de David Simple, com um agravante para o herói: são colocadas em primeira linha as diferenças de nível social e de poder aquisitivo. Todos os personagens são construídos em função desta diferença, especialmente em detrimento de David. Também são retomados com maior força elementos da discussão filosófica que já havia sido anunciada na primeira parte do

\footnotetext{
${ }^{81}$ [uma pequena moradia (...) a apenas uma milha da grande estrada de Londres.]
} 
romance - como, por exemplo, os caminhos que tomam a razão e a benevolência em cada indivíduo.

Mr. Orgueil reaparece, aqui, como vizinho da família na pequena cidade de Heddington, proprietário de um "large Estate, with a very fine House on it: for Mrs. Orgueil brought him a Fortune of above Thirty thousand Pounds" ${ }^{\prime 2}$ (VL, 320). O antigo amigo de David é apresentado como um homem cuja filosofia de vida - "his Philosophy" - é a antítese do que o narrador parece propor como conduta ética e moral. Assim, no capítulo quarto do sexto livro, Mr. Orgueil é descrito nas seguintes cores:

He was generally in his Study, contemplating on his Rule of Rectitude, and exulting in the Beauties of Human Reason; that if any Man should be so mad as to blaspheme this his much reverenced Idol, he might be ready to do his Duty, and write an elaborate Rhapsody in its Justification ${ }^{83}$. (VL, 353)

E mais adiante, no capítulo quinto:

He so implicitly worshiped Human Reason, that it appeared to him no less than Idolatry to dispute its Omnipotence; he, therefore, must necessarily condemn every Man, who is unfortunate whilst this powerful God is part of him.To have a Deity at his Command, and yet be miserable, how absurd! for, according to Mr. Orgueil's Way of thinking, this all-powerful God, Human Reason, is yet subject to the Will of Man, and he may use it or not, worship it, abuse it, or do whatever he please with it ${ }^{84}$. (VL, 357)

Trata-se de um homem, portanto, que acredita na razão com fé quase religiosa. Dentro da lógica do romance, este traço é o que torna o personagem moralmente condenável, pois impede que aja nos momentos em que, segundo o narrador, a razão deve

\footnotetext{
${ }^{82}$ [grande propriedade, com uma casa excelente, pois a Sra. Orgueil lhe havia trazido uma fortuna acima de trinta mil libras]

${ }^{83}$ [Ele ficava geralmente em seu escritório, contemplando sua regra de retidão, e exultando com as belezas da razão humana; e se algum homem fosse louco o suficiente para blasfemar seu tão reverenciado ídolo, ele estaria pronto para cumprir com o seu dever, e escrever uma elaborada rapsódia em sua defesa.]

${ }^{84}$ [Ele venerava tão implicitamente a razão humana, que lhe parecia nada menos que idolatria questionar a sua onipotência; ele, portanto, deve condenar necessariamente qualquer homem que é infeliz tendo este deus poderoso em si. Ter uma divindade a seu dispor e ser infeliz, que absurdo! Pois, de acordo com a maneira de pensar de Sr. Orgueil, este deus todo poderoso, a razão humana, está ainda assim sujeita à vontade do homem, e este pode usá-la ou não, venerá-la, abusá-la, ou fazer o que quiser com ela.]
} 
ceder o lugar à compaixão. Assim, quando o pai de Valentine e Camilla adoece e David pede o auxílio financeiro de Orgueil, os "debates internos" deste último levam tanto tempo - "whislt Mr. Orgueil was in this Debate with himself" - que a morte chega antes. Do mesmo modo, o narrador desculpa Orgueil pela omissão no caso dos maus tratos dados por sua mulher à filha de Cynthia, pois sua veneração pela razão o teria impedido novamente de agir.

É possível afirmar que, em Volume the Last, Sarah deixa de lado técnicas emprestadas a Richardson, mas não se afasta totalmente do modelo de Fielding. Por outro lado, parece claro que os elementos apontados acima extrapolam a visada que a leitura de Ian Watt sobre Fielding parecia nos oferecer. A reorganização do espaço e do tempo, a reavaliação de traços de caracterização e a presença mais importante de uma tentativa de debate filosófico indicam outro movimento na fatura.

Se as primeiras impressões apontam para o fato de que os modelos de H. Fielding e Samuel Richardson encontraram seus caminhos dentro das duas partes do romance de Sarah, existe um elemento crucial em sua construção, o qual se evidencia quando observamos os elementos richardsonianos e fieldinguinianos em justaposição em David Simple e Volume the Last - e o qual a própria análise em justaposição impede de avaliar as conseqüências. Trata-se do encontro formal de duas perspectivas, encontro que desemboca numa estrutura diversa daquelas propostas pelos modelos.

Resta compreender que sentidos resultam deste encontro formal que nenhum dos dois modelos propôs. Entramos aqui no território preciso do que coube à romancista selecionar para formalizar em seu romance. Trataremos em seguida de suas especificidades, e de seus resultados na fatura de David Simple. 
Capítulo 2: Contendo um passeio filosófico-sentimental que surpreenderá o Leitor 


\section{Passeio filosófico-sentimental}

“São as miseráveis convenções que pervertem os homens, e não a natureza humana que se deve acusar. Com efeito, o que nos afeta tanto quanto a narrativa de uma ação generosa?"

(Diderot, Discurso sobre a Poesia Dramática)

1. Mistura fina

A estrutura de David Simple anuncia uma simultaneidade de caminhos formais dentro da história da ascensão do gênero que uma análise baseada nas pistas deixadas por Watt não levaria a perceber inteiramente. A idéia da simultaneidade é, portanto, essencial para compreendermos que rumos tomaram as influências formais de Richardson e $\mathrm{H}$. Fielding dentro da narrativa de Sarah F., já que é da combinação destas que se estrutura o romance como totalidade.

Neste sentido, o estudo de Michael McKeon sobre as origens do gênero contribui de modo central para esta análise. McKeon parte do pressuposto segundo o qual, em A Ascensão do Romance, Watt parece observar o gênero em seu período de formação a partir de uma perspectiva que não se atém suficientemente à dinâmica segundo a qual as narrativas inglesas dos séculos XVII e XVIII internalizam questões de forma e conteúdo tendo em vista que "nascem" e se desenvolvem em ambientes históricos conflitantes ${ }^{85}$.

McKeon entende que o romance se definiria, neste período, pela instabilidade de categorias, tanto no que se refere às formas - o que o crítico nomeia de "questões de verdade" -, quanto no tocante aos conteúdos - identificados como "questões de virtude".

\footnotetext{
${ }^{85}$ McKEON, Michael, The Origins of the English Novel 1600-1740, Baltimore: John Hopkins University Press, 1987.
} 
O romance funcionaria deste modo como "mediador" para mudanças sociais e epistemológicas na intersecção da lenta passagem de um mundo fundamentalmente regido pela ordem aristocrática para outro em que os modos burgueses imperam. É a forma artística que encarna o centro dinâmico onde ocorre o encontro entre tais categorias divergentes.

Neste sentido, o gênero se configura como "abstração simples" - e aqui McKeon utiliza a terminologia marxista -, na medida em que se apresenta como uma "deceptively monolithic category that encloses a complex historical process" ${ }^{\prime 6}$. Assim é que o crítico observa, dentro da emergência do romance, três momentos marcantes - mas não necessariamente consecutivos - no que diz respeito às formas literárias (como contar a verdade?) e aos conteúdos selecionados (o que é a verdade numa história?).

O primeiro agrupa as expressões do "idealismo romanesco" - como questão de verdade - e da "ideologia aristocrática" - no âmbito das questões de virtude ${ }^{87}$. O crítico entende que, no início do período que lhe interessa - século XVII inglês -, a verdade era significada através de narrativas que correspondiam a estruturas e modelos sociais bastante rígidos e definidos. Era o mundo do que costuma ser chamado de "romanesco". Entram aqui as histórias intermináveis no estilo do francês L'Astrée, de Honoré d’Urfé romance francês de cinco mil páginas, publicado de 1607 a 1627, e que mistura mil e uma reviravoltas fantásticas a partir do mote do amor impossível entre Astrée e Céladon...

Estas narrativas tornaram-se pouco a pouco alvos de uma forma literária cujo recorte do mundo se distanciava da fantasia e se aproximava da experiência - segunda "etapa" identificada por McKeon como "empirismo ingênuo". Ao invés de um universo ocupado por príncipes heróicos em castelos longínquos, ou pastoras em bucólicos paraísos terrestres, as narrativas começam a dar notícia de vidas simples, triviais, mais próximas do que de fato costumava-se encontrar pelos campos ou pelas ruas das cidades.

\footnotetext{
${ }^{86}$ [uma categoria enganosamente monolítica que encerra um processo histórico complexo] McKEON, Michael, op. cit., p.20.

${ }^{87}$ Para facilitar a leitura, os termos utilizados por McKeon foram traduzidos quando não houvesse prejuízo à compreensão.
} 
O exagero das aventuras em cascata é substituído, nestes casos, por uma linguagem menos pomposa, também mais prosaica, procurando lidar com os detalhes sem importância de que são compostas nossas vidas cotidianas.

O empirismo que sobressai na fatura tem como fundamento o que o crítico identifica como "ideologia progressista" - na direção oposta, portanto, das bases sobre as quais o romanesco costumava funcionar. Sob esta perspectiva, McKeon interpretou o empirismo como uma forma de negação do romanesco, assim como a "ideologia progressista" - representada em grandes linhas pela ideologia da classe burguesa emergente - funcionava como uma espécie de reação à ideologia característica da aristocracia.

Contudo, vale notar que, com este esquema, McKeon não pretende estabelecer uma série de dicotomias rígidas, nem apresentar um movimento de ação e reação dentro do qual uma tendência significaria a imediata anulação da outra. As narrativas que lidam com os detalhes da vida de todo dia - como os romances de Richardson - ganham espaço, mas ainda competem, na preferência dos leitores, com as histórias fantásticas de princesas, castelos e viagens mirabolantes.

Por outro lado, é necessário observar que, no caminho que trilhava o "novo" romance, a tentativa de reproduzir a realidade mais cotidiana procurava se afirmar como epistemologia substituta à verdade fantástica dos romances de cunho maravilhoso. $\mathrm{O}$ método epistolar e a busca constante por um detalhamento minucioso teriam permitido ao autor de Pamela tirar proveito da idéia da história documentada, da objetividade ausentes no romanesco - e assim propor, no domínio da ficção, este critério de verossimilhança. Com o apelo premente à "realidade", seus textos podiam ser vistos como meios efetivos de instrução, em acordo com a convicção protestante de que a melhor mediação para se atingir os fins espirituais eram exemplos concretos. Procuravase por este caminho também redimir o romance, já que existiam, como é conhecido, sérias suspeitas quanto à idoneidade do gênero.

Curiosamente, esta dedicação ao empirismo é tão intensa na técnica do "writing to the moment" que o resultado a que se chega é exatamente oposto, a saber, a expressão 
radical da subjetividade. Nos romances de Samuel Richardson, o nível de detalhamento é tamanho que a verossimilhança acaba por se apoiar em fortes bases subjetivas, talvez em detrimento das referências objetivas oferecidas pelo autor ${ }^{88}$. É nesse movimento dialético essencial entre subjetividade e objetividade que as narrativas deste tipo propulsam a força de seu efeito de verdade - e, no entanto, reside também aí o seu "ponto fraco".

Ainda segundo McKeon, esta forma empírica - junto com a "ideologia progressista" - se tornou rapidamente vulnerável a uma contra-argumentação de natureza conservadora. Assim é que o romance começa a denunciar, através de uma forma e de temas algo divergentes, a "falácia" que o empirismo procurava transmitir, acusando-o de ser tão "fictício" quanto as narrativas romanescas. O crítico identifica esta etapa como a que corresponde às formas do "ceticismo extremo". E aqui coloca a prosa de Henry Fielding.

O grande porta-voz deste funcionamento ideológico na estrutura de seus romances é o célebre narrador intruso que "põe as mangas de fora" nos capítulos introdutórios de Tom Jones (1749), mas que já vinha ensaiando seus primeiros passos desde a carreira teatral de H. Fielding. Este narrador “irônico e distanciado, não só se sente à vontade para comentar suas criaturas e as ações delas e, sem disfarce, manipular o tempo e a narrativa, mas também discute o próprio ato de escrita do romance, mantendo ao mesmo tempo que desafia o próprio mandamento da 'distância épica' ao acrescentar-lhe um tempero de modernidade (...)" ${ }^{, 89}$.

Sem muito esforço, é possível entender a briga que o autor de Joseph Andrews estava disposto a comprar com seu êmulo Richardson. No lugar da pretensa ausência de mediação, aparece uma voz presente e intrometida que denuncia tudo que o modo dramático quer "naturalizar". Contra a singela virtude de personagens que tomam a palavra para narrar, no ato, suas agruras, H. Fielding opõe a ligeireza do grande mundo em que as pessoas não se revelam pelo que têm de "subjetivo", mas pelo que têm de

\footnotetext{
${ }^{88}$ Ver McKEON, Michael. op. cit., p. 363-4.

${ }^{89}$ VASCONCELOS, Sandra G. T. Dez Lições sobre o Romance Inglês do Século XVIII. São Paulo: Boitempo Editorial, 2002. pp. 89.
} 
"humano". E, ça va sans dire, na esteira da crítica aos métodos "modernos" de impor a "credulidade" ao leitor entra também a sátira ao romanesco.

Ocorre que, ao recusar os fundamentos do pensamento progressista, a "ideologia conservadora" acaba por retomar elementos da lógica aristocrática que também se propunha a refutar. Para McKeon, este procedimento seria indicador do posicionamento ideológico do romancista, cuja expressão bastante clara se revela na idéia de colapso de categorias - através da clássica redução conservadora segundo a qual a 'virtude' progressista só reproduz, de outro modo, a velha arbitrariedade aristocrática... E assim a própria idéia de virtude individual torna-se suspeita (o que caracterizaria justamente o pensamento aristocrático! $)^{90}$.

A definição das questões de verdade e virtude permite a McKeon um certo "contorcionismo conceitual" que, no entanto, é bastante útil para que se resolvam principalmente duas dificuldades encontradas no estudo de Ian Watt. A primeira delas diz respeito à persistência do romanesco e da aristocracia dentro do processo de formação do romance como gênero, no mesmo momento em que a burguesia dava passos largos em direção à hegemonia. A dinâmica estabelecida entre as diferentes categorias evita que se imponha uma cronologia ferrenha aos processos históricos, possibilitando entrever a realidade como um espaço de intersecção - muitas vezes conflituosa - de diferentes estruturas sociais e ideológicas. Romanesco e romance dividem, ou disputam, o mesmo espaço e o mesmo tempo.

Este ponto de vista oferece ainda a vantagem de resolver a segunda dificuldade marcante na perspectiva de Watt: a impossibilidade de compreender Henry Fielding dentro do processo de formação do gênero - assim como o funcionamento da mudança social dentro de seus romances. O esquema de McKeon evita este percalço na medida em que apresenta a persistência da tradição como uma categoria constituinte do próprio gênero - e não como uma "presença alienígena" - ao mesmo tempo em que expõe as circunstâncias históricas que regulavam as escolhas de Fielding. Sob esta perspectiva,

\footnotetext{
${ }^{90}$ Ver McKEON, Michael. op. cit., p. 387. No que diz respeito a Henry Fielding, McKeon analisa o romance Jonathan Wild (1743).
} 
portanto, as ideologias progressista e conservadora, contemporâneas na Inglaterra de meados do século XVIII, colocam em contato, naqueles mesmos espaço e tempo, "técnicas" diferenciadas de recorte da realidade.

O que nos interessa neste debate é a possibilidade de vislumbrar, em David Simple, a reprodução, formalizada em material ficcional, do encontro - mais ou menos conflituoso - entre estas duas visadas comumente apresentadas de maneira separada dentro da história da formação do romance inglês. Quando observado sob este ponto de vista, o romance ganha novo sentido, e as "lentes" emprestadas adquirem significados que trazem elementos novos para a compreensão do tipo de contribuição de Sarah Fielding para a constituição do gênero.

\subsection{Vozes femininas}

Vimos que, nas mãos de Richardson, a estrutura epistolar e o diário tornam-se as formas consagradas para se lidar com a expressão de subjetividades - trata-se da forma "empírica" por excelência. Aqui já aparece uma pequena diferença entre seus romances e o nosso David Simple - diferença simples que, no entanto, se impõe subrepticiamente como dado fundamental na fatura do romance. A autora não escolheu a estrutura em cartas - ainda que existam cartas dentro do romance -, nem em diário.

Optou por elaborar pequenos blocos de capítulos que interrompem o fluxo da ação conduzida pelo narrador e no quais Cynthia, Camilla e Isabelle resolvem contar, em primeira pessoa, suas histórias de vida ${ }^{91}$. Nesta escolha formal, fica evidente que não há recurso ao "writing to the moment", nem mesmo à narração oral dos fatos conforme ocorrem. Isto porque parece que, em David Simple, o interesse não reside propriamente em expor as minúcias do sentimento e dos sobressaltos que acompanham cada acontecimento no dia-a-dia dos personagens.

\footnotetext{
${ }^{91}$ Respectivamente, livro II, capítulos VI-VIII; livro II, capítulo X e livro III, capítulos I-II; livro III, capítulos VII e livro IV, capítulos I-II.
} 
A "lição" e o exemplo - intenções subjacentes também à prosa de Richardson - se oferecem por meio de um elemento que o "writing to the moment" não permitia com facilidade: o espaço de tempo entre os fatos acontecidos e narrados, ou seja, a reflexão sobre o acontecido. A narrativa da experiência subjetiva de cada uma das mulheres se constrói, portanto, com o auxílio da reflexão e do julgamento. O efeito de verdade aparece no jogo entre sentimento e pensamento, numa lógica bastante precisa que o modelo de Richardson não inclui necessariamente.

Esta combinação entre sentimento e reflexão, subjetividade e pensamento tem nuances específicas na construção da cada um dos três personagens femininos. No caso de Cynthia, a expressão da experiência individual é claramente firmada na elaboração de raciocínios bastante precisos. Temos, logo de imediato, acesso ao conflito entre a moça e o mundo que a cerca - "I cannot say, I ever had any Happiness in my Life" 92 -, tanto na relação com sua família, como na experiência com Lady -----. De fato, Cynthia não corresponde às expectativas sociais:

I never spoke, but I was a Wit; if I was silent, it was Contempt. I certainly would not deign to converse with such People as they were. Thus whatever I did, disobliged them; and it was impossible to be otherwise, as the Cause of their Displeasure was what I could not remove ${ }^{93}$. (DS, 103)

Porém, o que impossibilita sua inserção no mundo em que vive não é exatamente uma paixão imprópria, ou o desrespeito deliberado aos valores correntes. Segundo ela, é sua inteligência - ou "wit" - a principal fonte de suas dificuldades. De tal modo que a moça quase lamenta o fato de carregar tamanho fardo: "I have been so teazed and tormented about Wit, I really wish there was no such Thing in the world" (DS, 101) $)^{94}$. O leitor que não se deixe enganar, no entanto, pois o que segue este desabafo um pouco

\footnotetext{
92 [Não posso afirmar que jamais tenha tido felicidade em minha vida]

${ }^{93}$ [Sempre que eu falava, era espirituosa; se ficasse quieta, era desprezo. Eu certamente não me dignaria a conversar com pessoas como elas. Logo, tudo o que eu fazia as ofendia; e era impossível ser de outro modo, já que eu não tinha como eliminar a causa do seu desagrado.]

${ }^{94}$ [Já fui tão provocada e atormentada por causa da inteligência que realmente desejaria que tal coisa não existisse no mundo]
} 
lamentoso é uma organização bastante precisa do pensamento - apoiada, ademais, pela "autoridade" de algumas leituras. Este apoio tem papel central na organização do pensamento do personagem; observemos, através de dois exemplos emblemáticos, como ele se traduz.

O primeiro é a referência a Essay on Criticism, poema didático de Alexander Pope, publicado anonimamente pela primeira vez em 1711. Pope toma posição no debate sobre o papel e a função da crítica, enfileirando-se, ao longo dos versos, do lado da visada neoclássica, em detrimento das novidades que os letrados de inícios do século XVIII já viam circular. O trecho citado por Cynthia $^{95}$ se refere justamente ao que Pope chama de "ornamental wit", um dos entraves, segundo ele, para um julgamento crítico correto de uma obra. Diz Cynthia:

The Fate of those Persons who have Wit, is no where so well described, as in those excellent Lines in the Essay on Criticism, which are so exactly suited to my present Purpose, I cannot forbear repeating them to you (... $)^{96}$. (DS, 98)

Os versos evidentemente colocam o possuidor de "wit" na pior das situações, pois a valorização da inteligência é apresentada como um engano de juventude, que perde logo seu frescor. O virtuoso deve fugir dela, pois mesmo que traga fama, esta inteligência tem conseqüências desastrosas - é fonte de inveja, discórdia e desentendimento. A temática do "wit" é recorrente em diferentes tipos de textos da época - além de romances e ensaios, aparece com bastante freqüência nos periódicos. A indagação parecia ser a mesma: compreender o que significava ter presença de espírito no jogo social; seria uma característica boa, a ser cultivada pelos indivíduos?

\footnotetext{
${ }^{95}$ Unhappy Wit, like most mistaken Things, / Atones not for that Envy which it brings; / In Youth alone its empty Praise we boast, / But soon the short-liv'd Vanity is lost: / Like some fair Flower, the early Spring supplies, / that gaily blooms, but even in blooming dies. / What is this Wit, which must our Cares employ? I The Owner's Wife, that other Men enjoy: / The most our Trouble still, when most admir'd, / The more we give, the more is still requir'd. /The Fame with Pains we gain, but lose with Ease; /Sure some to vex, but never all to please: / 'Tis what the Vicious fear, the Virtuous shun, / By Fools 'tis hated, and by Knaves undone.

${ }^{96}$ [O destino daquelas pessoas que têm inteligência não está tão bem descrito em nenhum outro lugar como naqueles excelentes versos do Essay on Criticism, os quais se adaptam tão bem aos meus objetivos, que não posso deixar de repeti-los para você]
} 
As opiniões eram divididas. Entre "good wit", "bad wit", "ornamental wit" e outras classificações, se desenhavam o mundo da "polidez" e as regras sociais que faziam parte dele. Também está implicada neste debate a própria definição de indivíduo no que se refere à sua relação com o pensamento e com as idéias. O que nos interessa, no entanto, é compreender em que medida a posição conservadora de Pope se torna elemento constituinte da tentativa de Cynthia de expressar seus sentimentos em relação a seu próprio destino.

O trecho do poema de Pope pode funcionar como exemplo negativo - indicando o que não se deve fazer -, mas o modo dramático impede que o leitor se afaste inteiramente do personagem e o associe de forma maniqueísta ao comportamento condenável que o poema critica. Instalada esta ambigüidade, recebemos a citação como mais um elemento na constituição dramática do personagem, como um dado que alimenta o conflito da moça com seu grupo. O exemplo aparece "disfarçado", assim como na prosa de Richardson. A diferença é que aqui ele se desenvolve sob uma perspectiva diversa daquela adotada pelo autor de Pamela na medida em que propõe o pensamento organizado como aspecto da vida psicológica do indivíduo.

Do mesmo modo, um pouco mais adiante, Cynthia expõe suas reflexões em relação à inteligência. Afirma:

(...) if Wit consists, as Mr. Locke says, in the Assemblage of Ideas, and Judgement in separating them; I really believe the Person who can join them with the most Property, will separate them with the greatest Nicety. A Metaphor from Mechanism, I think, will very plainly illustrate my Thoughts on this subject: for let a Machine, of any kind, be joined together by an ingenious Artist, and I dare say, he will be best able to take it apart again (... $)^{97}$ (DS, 104-105).

Em meados do século XVIII, o Ensaio sobre o entendimento humano, de Jonh Locke, publicado em 1689-90, já havia percorrido seus caminhos na direção da

\footnotetext{
${ }^{97}$ [Se a inteligência consiste, como afirma o senhor Locke, na reunião de idéias e na capacidade de separálas; eu realmente acredito que a pessoa que possa juntá-las com a maior propriedade, poderá separá-las da melhor maneira. Uma metáfora do mecanismo, eu acho, pode ilustrar meus pensamentos sobre este assunto: pois ponha uma máquina, de qualquer tipo, para ser montada por um artista engenhoso, e eu ouso dizer que ele será o mais apto a desmontá-la (...).]
} 
popularização. Nos meios "especializados", o caráter polêmico de seu ensaio permaneceria vivo para muita gente dos dois lados do Canal da Mancha - de Samuel Johnson a Sterne, passando pelos filósofos-enciclopedistas - durante todo o século. Mas, para além das fronteiras restritas do mundo intelectual, vários periódicos de circulação mais abrangente passaram a reproduzir com regularidade passagens do texto de Locke. Entre eles figura The Spectator, de Addison e Steele ${ }^{98}$, no qual, em muitas ocasiões, a ficção servia de ilustração para algum princípio filosófico lockeano.

A discussão acerca das idéias - e da relação destas com o conhecimento - entrou, assim, na ordem do dia também para o leitor comum, para o qual os periódicos eram fontes seguras de informação, diversão, educação moral. Os periódicos de Addison e Steele parecem, de fato, ter sido responsáveis pela popularização, em grande escala, da "nova filosofia", além de servirem como meios diretos para a propagação de valores em acordo com os novos modos de viver. Alguns acreditavam que os textos de Addison e Steele ditavam de fato as novas regras de comportamento: para Samuel Johnson, antes do Spectator e do Tatler, "England had no masters of the common life",99.

Este caminho tomado pela filosofia de Locke abre espaço para um imenso campo de investigação que é a relação entre os periódicos e os romances setecentistas - relação já insinuada em diferentes momentos deste estudo. A fim de evitar mais uma vez a entrada nesta matéria, digamos apenas que parece claro ter havido influência de periódicos - especialmente o Tatler e o Spectator - no romance de Sarah Fielding; sabese que foi leitora de Addison - era um de seus autores prediletos - e faz referência direta ao Tatler pelo menos uma vez em David Simple ${ }^{100}$.

De qualquer modo, o que parece pertinente, neste caso, é a referência a Locke como elemento constituinte do personagem Cynthia. A referência aparece como uma "nota" que, reproduzindo "sons" da sociedade, revelaria o quanto questões específicas à

\footnotetext{
${ }^{98}$ Ver a este respeito interessante artigo de Hans Aarsleff, "Locke's influence", in: CHAPPELL, Vere (ed.), The Cambridge Companion to Locke, Cambridge: Cambridge University Press, 1995. pp. 252-289.

${ }^{99}$ [A Inglaterra não tinha mestres da vida comum] in: PORTER, Roy. The Creation of the Modern World. The Untold Story of the British Enlightenment. London: W.W. Norton \& Company, 2000. p. 80. ${ }^{100}$ Livro II, cap. 10. p. 143.
} 
constituição do indivíduo já faziam parte do cotidiano de uma camada da sociedade inglesa deste período - da qual participavam também as mulheres.

Este aspecto essencial da psicologia de Cynthia vai se desenrolando no mesmo tom ainda quando não são feitas menções diretas a autores ou leituras. Aparece inclusive em seu uso da linguagem: a moça utiliza, em duas ocasiões, expressões que causam espanto e dúvida em David, sendo convidada a explicar o sentido destas ao herói. Ao ouvir de Cynthia o quanto suas irmãs se deleitavam em zombar de sua prima - "making a Butt of this poor Girl" -, David pergunta: "Pray, Madam, (...) what is the meaning of making a Butt of someone?" 101 (DS, 106). Do mesmo modo, quando a moça se define como "toad-eater" 102, o herói novamente titubeia: "David begged an explanation of what she meant by Toad-eater; for he said it was a Term he had never heard before" 103 (DS, $113)$.

Além disso, o pensamento organizado de Cynthia é marca constante de seu discurso no que se refere a assuntos mais íntimos: a relação com os homens. Também neste quesito - leia-se corte e casamento -, Cynthia não corresponde ao que se espera dela em seu meio. Assim é que a moça conta a David como as irmãs a reprovaram quando assumiu que seguiria suas inclinações afetivas na escolha de um marido; e relata um episódio em que recusou um pretendente que havia negociado casamento com seu pai dizendo: "I made him a low Court'sey, and thanked him for the Honour he intented me; but told him, I had no kind of Ambition to be his upper Servant" ${ }^{104}$ (DS, 109).

O casamento arranjado não ocorreu, e Cynthia expressa claramente o que pensa sobre as mulheres que aceitam esta situação: "for I shall always call it Prostitution, for a Woman who has Sense, and has been tolerably well educated, to marry a Clown and a

\footnotetext{
${ }^{101}$ [transformar a pobre garota em alvo]; [Por favor, senhora, (...) o que significa transformar alguém em alvo?]

${ }^{102}$ Literalmente, engolidora de sapos.

${ }^{103}$ [David pediu uma explicação sobre o que ela quis dizer com 'engolidora de sapos'; pois ele disse que se tratava de um termo que nunca havia escutado.]

104 [Cumprimentei-o, e agradeci pela honra que me oferecia; mas disse a ele que não tinha nenhuma ambição de tornar-me sua criada.]
} 
Fool" ${ }^{105}$ (DS, 109). Conhecemos o preço pago pelo discernimento e pela educação: deserdada no testamento do pai, Cynthia acaba na posição pouco confortável de dependente - ou, como ela mesma explica, "Toad-eater" - junto a Lady

Durante sua viagem de volta a Londres (livro 3, capítulo 4), Cynthia divide a carruagem - ou Stage-coach - com três homens identificados como o Clérigo, o Ateu e o Borboleta - Clergyman, the Atheist e the Butterfly. O Ateu e o Clérigo tentam seduzi-la, cada um à sua maneira, em momentos diferentes do trajeto. A recusa de Cynthia é categórica em ambos os casos, e justificada pela demonstração - através da voz do narrador - do que ela pensou nas duas situações. No caso do Ateu, ela "could not help smiling, to see a Man endeavouring to persuade her, that she might follow her Inclinations without a Crime, while she knew that nothing could so much oppose her gratifying him, as her pleasing herself ${ }^{\prime 106}$ (DS, 181). No que se refere ao Clérigo, sua decisão é igualmente refletida: “(...) her heart was already so fixed, that she resolved never to suffer any other Man to make Love to her" ${ }^{107}$ (DS, 184).

Também nas relações pessoais, a experiência subjetiva de Cynthia é dominada pelo pensamento organizado - a paixão nunca aparece como elemento significativo dentro de seu relato autobiográfico. É desta estruturação específica que o personagem tira sua força dramática. A presença forte de Cynthia até o último suspiro de David, em Volume the Last - é ela que garante a sobrevivência do que restou da "little Family" do herói - ganha bastante sentido diante desta visão global do personagem. Assim é que, no último capítulo da segunda parte da história, o narrador relata:

She [Cynthia] told little Camilla, that if David asked for her, she should be at home in the Evening; and walked toward the great Bath Road: not that she supposed she could walk to the Bath, but she knew of the two Stages Coaches that went by very early, and in one of them she doubted not she should find

\footnotetext{
105 [Pois sempre chamarei de prostituição, para uma mulher que tem discernimento, e é minimamente educada, casar-se com um palhaço e um bestalhão]

106 [não pôde deixar de sorrir ao ver um homem tentando persuadi-la de que ela poderia seguir suas inclinações sem parecer criminosa, enquanto ela sabia que nada se opunha mais à gratificação dos desejos dele do que a vontade dela de agradar a si mesma.]

${ }^{107}$ [seu coração estava tão decidido que ela resolveu não permitir que nenhum outro homem caísse de amores por ela]
} 
Room. She (...) was resolved to set before the Master of it [da família] David's Condition and the Situation of her Niece ${ }^{108}$. (VL, 427-428)

A presença poderosa do personagem serviu de mote, no âmbito da crítica, para leituras que carregaram Cynthia - e, por extensão, o romance de Sarah Fielding - por caminhos menos esclarecedores. As feministas se interessaram rapidamente por este personagem e, de modo geral, pelos romances escritos por mulheres - como também pela importância (ou a irrelevância) da influência dos romances escritos por homens na produção feminina ${ }^{109}$. Vale um ligeiro desvio por algumas páginas desta tradição crítica para compreendermos em que medida o interesse feminista contribuiu para que aumentasse a curiosidade pelo romance e pelo personagem, mas se distanciou das principais questões colocadas na obra de Sarah F.

Dale Spender ${ }^{110}$ desenvolve, em Mothers of the Novel (1986), a idéia segundo a qual foram muitas e muitas mulheres (segundo ela, pelo menos cem escritoras antes de Jane Austen) que contribuíram fundamentalmente para o estabelecimento do romance como gênero - e não a meia dúzia de homens que habitualmente ocupam as páginas dos manuais de literatura. Pioneiras da forma, essas figuras corajosas teriam utilizado o romance como o veículo por excelência para novos conteúdos, expressando suas vozes e reivindicações.

\footnotetext{
108 [Ela disse à pequena Camilla que, se David perguntasse por ela, estaria em casa à noite; e caminhou na direção da grande estrada de Bath: não que acreditasse poder caminhar até Bath, mas sabia de duas carruagens que passavam por ali bem cedo, e numa destas não duvidava que poderia conseguir um lugar. Ela (...) resolveu apresentar ao senhor a condição de David e a situação de sua sobrinha.]

109 Os trabalhos desenvolvidos na perspectiva conhecida nos meios feministas como "Anglo-American" trazem para o centro da análise a especificidade da escrita feminina, examinando como se organizaria uma tradição no que se refere às mulheres autoras e como se definiria uma cultura específica deste grupo. A chamada crítica anglo-americana - que, no entanto, parecia mais americana do que "anglo" - tinha como "comissão de frente" o estudo "ginocrítico" (sic) de Elaine Showalter, A Literature of their Own (1977) e o "monumental" The Madwoman in the Attic (1979), de Sandra Gilbert e Susan Gubar. Estes trabalhos e seus herdeiros - procuravam fundamentalmente promover o estudo das obras de mulheres escritoras esquecidas e o desenvolvimento de um discurso crítico feminista de fato.

${ }^{110}$ Identificada por Peter Widdowson e Raman Selden em seu A Reader's Guide to Contemporary Literary Criticism (1993) como uma feminista da "segunda geração" - que se seguiu a Virginia Woolf e Simone de Beauvoir -, Spender é autora de Man Made Language (1980), na qual trata da opressão feminina pelo domínio absoluto dos homens sobre o discurso. Esta perspectiva, ainda segundo Widdowson, segue a argumentação de Michel Foucault para o qual a 'verdade' se define a partir daquele que controla o discurso...
} 
O argumento central de seu estudo sobre David Simple se organiza em torno da idéia segundo a qual Sarah F. teve o mérito de apresentar uma dimensão da vida inglesa que escapou ao olhar de seus contemporâneos masculinos: "this is a novel which only a woman could have written"111. Este olhar diferenciado se revela na apresentação da posição das mulheres na relação desigual entre os sexos - o que faz, segundo Spender, com que percebamos o quanto as coisas continuam as mesmas depois de mais de 250 anos...

O personagem Cynthia aparece aqui como veículo para as idéias da autora, esclarecida bluestocking, a propósito desta fundamental diferença de estatuto entre homens e mulheres na Inglaterra setecentista - e que, de acordo com Spender, deixou suas marcas pelo século XX. Observamos então Cynthia como uma moça cuja independência na relação com interlocutores masculinos é freqüentemente contestada. Spender retoma o episódio da sedução no Stage-coach:

(...) Cynthia, who is travelling in a stage coach in the company of three 'gentlemen' whom the author characterises variously as 'the clergyman', 'the atheist' and 'the butterfly'. Cynthia is preoccupied with her own thoughts, is perfectly self-contained, and not only refrains from talking but is quite oblivious to what the gentlemen are saying. But is she to be permitted her solitude and her independence of her male travelling companions? Oh no. (...) Sound familiar? Not even the arguments [men's] seem to have changed with the passing of time. ${ }^{112}$

A autora entende que, através de episódios deste tipo, Sarah F. descreveria comportamentos machistas e as dificuldades encontradas pelas mulheres que se dão ao respeito e valorizam sua própria inteligência. Estas características aproximam Cynthia das mulheres atuais, colocando a escritora em comunicação direta com a leitora da época

\footnotetext{
${ }^{111}$ [este é um romance que só uma mulher poderia ter escrito.] SPENDER, Dale. op. cit., p. 186.

112 [Cynthia, que viaja numa carruagem na companhia de três 'cavalheiros' caracterizados pela autora como 'o clérigo', 'o ateu', 'o borboleta'. Cynthia está entretida em seus pensamentos, perfeitamente concentrada, e não só evita falar, mas não presta atenção no que os cavalheiros estão dizendo. Mas será que lhe serão permitidas a solidão e a independência de seus companheiros de viagem? Ah não. (...) Soa familiar? Nem mesmo os argumentos (dos homens) parecem ter mudado com o tempo.] SPENDER, Dale. op. cit., pp. 187-188.
} 
e de hoje. O estilo de Sarah Fielding seria, assim, marcadamente feminino, em oposição a um estilo masculino, pouco revelador da natureza das relações e da realidade vividas pelas mulheres naquele universo. Este argumento se justificaria na medida em que descrições deste tipo de situação trazem à narrativa elementos palpáveis da vida cotidiana das mulheres, o que não seria tão fácil de encontrar em histórias escritas por homens.

Deste modo, na cena em que Cynthia se vê obrigada a recusar os avanços de seus três companheiros de viagem (cap. XXX), Spender observa uma operação delicada e sutil de mudança de perspectiva, passagem de um ponto de vista "androcêntrico" - que ela identifica em Pamela - para outro, caracterizado como "ginocêntrico" (sic). Se em Pamela o tema do assédio sexual é tratado de maneira "blasé", "fashion "procrastinated rape", em David Simple a realidade apareceria nua e crua - ou quase.

Em tom menos indignado, Jane Spencer retoma o problema das influências com The Rise of the Woman Novelist (1993), um estudo que pretende discutir a recepção da prosa feminina na Inglaterra setecentista pela crítica da época, assim como apontar alguns temas marcadamente femininos nas obras destas autoras ${ }^{113}$. Ainda sob o viés da reabilitação das romancistas dentro da história "oficial" da formação do romance, Spencer procura observar de que maneira algumas autoras esquecidas contribuíram para esta história. Sua reflexão se estende à relação entre a gradual "feminilização" da literatura e a exclusão concomitante das mulheres da vida política, social e econômica.

A suposta "feminilidade" do estilo de Sarah Fielding reaparece, mas aqui sob o ponto de vista da aceitação. Sarah teria escrito "femininamente" para não perder o apoio intelectual e logístico de seus dois grandes paradigmas. Spencer entende, portanto, que se Richardson e Fielding incentivaram Sarah F. - e outras autoras - à composição de romances, reconhecendo seus talentos, trata-se de uma abertura concedida por estes homens a algumas mulheres - talvez por terem quase certeza que estas não representavam qualquer perigo à situação vigente entre os sexos.

\footnotetext{
${ }^{113}$ Neste primeiro livro, Jane Spencer comenta obras de oito autoras diferentes: Aphra Behn, Delariviere Manley, Jane Barker, Elizabeth Rowe, Penelope Aubin, Sarah Fielding, Fanny Burney e Eliza Haywood. Em seguida, publicou Elizabeth Gaskell (1993) e Aphra Behn's Afterlife (2000), nos quais se concentra nas obras destas duas escritoras.
} 
É dentro deste contexto que Spencer procura compreender David Simple. Observa-o, portanto, como um romance satírico-sentimental (misturando técnicas das duas fontes), colocando em cena personagens típicos, utilizados como veículos dos julgamentos morais da autora. Cynthia aparece como a representação dos preconceitos sofridos pela própria Sarah F. em função de sua inteligência e competência, que iam além das prendas domésticas.

Através de seu personagem, Sarah Fielding defenderia uma situação social mais digna para as mulheres, na qual a educação tivesse prioridade e o casamento de conveniência não fosse uma prática regular. Esta posição da autora justificaria a cena em que o pretendente de Cynthia se apresenta - "he supposed my Father had informed me that they two were agreed on a Bargain"114 (DS, 108) - e é sumariamente recusado pela moça.

Deste modo, S. Fielding afirmaria com ironia que, enquanto a situação não evoluísse, o conhecimento não poderia trazer nenhuma felicidade a uma mulher, já que acabava por deixá-la sem recursos e sem família... Porém, Spencer observa que o tom rebelde que caracteriza Cynthia desaparece das narrativas posteriores da autora, já que era preciso garantir a aprovação masculina. O melhor método parecia ser, ainda segundo esta análise, negar qualquer tipo de comportamento - social ou literário - que pudesse sugerir um risco à supremacia dos homens.

Quase quarenta anos depois da publicação de Thinking about Women (1968), de Mary Ellman, e de outros textos fundadores da crítica literária feminista, os temas se diversificaram bastante, mas as questões fundamentais resistem. Como definir o caráter essencialmente feminino em uma obra? Onde começa a tradição na perspectiva de uma literatura feminina? Existe realmente uma escrita "feminina"? Quais são suas características?

Não temos a pretensão de entrar no labirinto ao qual conduz a busca pelas respostas a estas perguntas. De todo modo, importa aqui tomar posição no que se refere

\footnotetext{
${ }^{114}$ [ele supunha que meu pai tivesse me informado que eles dois tinham combinado uma barganha]
} 
ao problema do elemento feminino (ou feminista) no romance de Sarah Fielding, especialmente no que se refere a Cynthia - já que o trabalho de pesquisa deste tipo de crítica é, de certo modo, responsável pela "reaparição" da autora sob a forma de reedições e de estudos como este.

A discussão feminista anglo-saxã dos anos 60 a 80 do século passado tem o mérito de ter colocado em pauta problemas relacionados à luta pelo poder nas relações de gênero. $\mathrm{O}$ caráter político fundamental destas iniciativas parece assim evidente $\mathrm{e}$ indiscutível. É preciso sempre lembrar, do mesmo modo, que a crítica literária dentro desta etapa do movimento feminista não tinha fronteiras estabelecidas com a crítica cultural - o que enriquece e traz vivacidade a ambientes acadêmicos provavelmente bastante enfadonhos, mas também dificulta separar o joio do trigo.

O lado perverso desta chamada "pluralidade" de tendências e perspectivas que caracterizaria os estudos originados nas “ondas" feministas deste período é que esta acaba gerando alguns problemas de difícil resolução. O primeiro, mais geral, se refere à tal "pulverização" de linhas de estudos literários dentro da causa feminista ${ }^{115}$. Sem entrarmos na complexidade dos detalhes, parece que a busca pela definição de uma literatura tipicamente feminina corre o risco de se apoiar em critérios que repetem os padrões da crítica "masculina" - como o positivo de um filme -, ou se sujeita ainda a procurar estabelecer padrões rígidos (e prescritivos) de produção e recepção. Parece-nos discutível o poder de mudança real que este tipo de estratégia encerra.

Em segundo lugar, existe o perigo de, nesta jornada, a crítica se afastar cada vez mais de seu objeto de estudo - sem que haja ainda assim garantia de que o recado político tenha sido devidamente transmitido... Portanto, o ajuste que se impõe aqui aponta

\footnotetext{
${ }^{115}$ Widdowson e Selden mencionam pelo menos cinco "focos" em discussões relacionadas à diferença sexual no que consideram a segunda "onda" feminista: a biologia (estudos que procuram identificar o papel do discurso "científico" na opressão feminina); a experiência (ou a diferença sexual ligada à maneira como os sexos "vivenciam" as experiências); o discurso (em que se debate se a dominação masculina se daria pelo poder sobre os modos de expressão); o inconsciente (Julia Kristeva, passando por Lacan e outros); e, last but not least, as condições econômicas e sociais (na Inglaterra, especialmente com o "Marxist-Feminist Literary Collective", cujas produções foram influenciadas por Althusser e Pierre Macherey). Ver WIDDOWSON, Peter e SELDEN, Raman. A Reader's Guide to Contemporary Literary Criticism, Hemel Hempstead: Haverster Wheatsheaf, 1993, p. 211.
} 
precisamente no sentido de evitar que a análise se afaste do objeto. No caso específico de David Simple, o foco da atenção na análise de Dale Spender é o comportamento do personagem Cynthia como porta-voz da batalha feminina, iniciada já em meados do século XVIII. Mesmo reconhecendo aspectos "progressistas" no personagem e desconsiderando o fato de que ela não enfrenta as instituições e os modos vigentes até as últimas conseqüências, entendemos que a opção pelo recorte marcadamente feminista acaba por dispersar a atenção dos problemas que o romance expõe.

O resultado são comentários que se organizam em dois níveis claramente separados. Há primeiro a identificação de elementos de cunho sociológico dentro do romance através do personagem Cynthia. Em segundo lugar, aparece uma análise formal e temática do romance que segue, em todas as letras, o caminho pré-estabelecido pelos esquemas da crítica tradicional. O romance é visto assim como satírico-sentimental, episódico, modelado conforme os padrões mencionados. Tanto no caso de Dale Spender quanto no de Jane Spencer, o trabalho crítico se perde na falta de unidade entre o desejo de observar certos elementos temáticos na narrativa e a ausência de análise cerrada da estrutura formal.

Ocorre assim o afastamento do objeto, já que, ao focalizar em elementos que não relevam da especificidade do texto literário, há sempre a possibilidade de reduzir a leitura do romance a um "sociologismo" com ímpetos panfletários pouco proveitosos à atividade crítica - e nunca é demais lembrarmos da tal "consciência da relação arbitrária e deformante que o trabalho artístico estabelece com a realidade"116. Ao procurar características que confirmem (ou desabonem) dados da realidade literal dentro do romance, acaba-se perdendo contato com a idéia da "fatura" - ou seja, de como o externo vira interno dentro da narrativa. Sem contato com o material formal propriamente dito que a idéia de fatura pode ajudar a manipular -, resta o recurso seguro ao jargão da crítica tradicional.

${ }^{116}$ CANDIDO, Antonio. Literatura e Sociedade. São Paulo: T.A. Queiroz Editor, 2000. p. 12. 
Uma possível saída para tais armadilhas é o caminho da "crítica integradora", que procure entender a obra como "processo" e "montagem"117 - evitando os dois extremos recorrentes, a saber, a crítica estritamente formalista, ou puramente sociológica. A realidade se manifesta na estrutura da narrativa através do que Antonio Candido denomina "redução estrutural", ou seja, "o processo por cujo intermédio a realidade do mundo e do ser se torna, na narrativa ficcional, componente de uma estrutura literária, permitindo que esta seja estudada em si mesma, como algo autônomo" ${ }^{118}$. E continua: "uma das ambições do crítico é mostrar como o recado do escritor se constrói a partir do mundo, mas gera um mundo novo, cujas leis fazem sentir melhor a realidade originária" 119 .

Assim, rejeitar as conclusões bem-intencionadas da crítica feminista não significa afirmar que o "feminino" não esteja presente na prosa de Sarah F. - significa que este talvez não esteja onde o buscavam. O teor conteudístico da narrativa de Cynthia pode até transformá-la na porta-voz de um suposto movimento protofeminista por parte das intelectuais - bluestockings e afins - da Inglaterra setecentista. Porém, a força do personagem não está exatamente aí.

Encontra-se no fato de que a subjetividade, a intimidade, os sentimentos de Cynthia se revelam também pelo discurso articulado. Esta característica central é o que torna o personagem verossímil dentro do romance e, projeta, assim, seu sentido para além deste. Portanto, a prosa de Sarah Fielding dá alguns passos adiante do projeto estritamente dramático dos romances richardsonianos. Oferece ao leitor uma narrativa em que vozes femininas "filosoficamente" articuladas - daí a grande novidade - auxiliam na estruturação do romance como um todo, atribuindo significados também para seus momentos episódicos.

Neste sentido, ao combinar sentimento e pensamento, o romance de Sarah Fielding lembra os recursos utilizados pelo romance filosófico - se entendermos que este

\footnotetext{
${ }^{117}$ CANDIDO, Antonio. op. cit., p. 124.

${ }^{118}$ CANDIDO, Antonio. op. cit., p. 9.

${ }^{119}$ CANDIDO, Antonio. op.cit., p. 10.
} 
gênero, identificado mais comumente na tradição francesa (através dos filósofos da Ilustração), se caracterizava pela tentativa de unir, dialeticamente, elementos à primeira vista paradoxais. Na tentativa de criar novos padrões para um gênero ainda em definição, o romance filosófico pretendia colocar em funcionamento, ao mesmo tempo, "teoria e eloqüência, verdade e ilusão, o 'homem de gênio', dotado de autodomínio racional, e o 'homem sensivel', que vive à mercê do diafragma"120.

Como filósofos, os autores destes romances desejavam deixar marcado, no leitor, o sentimento da verdade; como "poetas-dramaturgos", buscavam "encantar, interessar, comover, persuadir, 'entrar furtivamente na alma" ${ }^{121}$ daquele que lia. Assim, a verdade se construiria, no romance filosófico, através de um tratamento diferenciado do material ficcional: utilizando técnicas "dramáticas", referências a elementos da vida cotidiana e referências culturais comuns, o romancista vai tecendo a trama e inserindo, em meio desta, os fios que estabelecem suas bases morais.

Quando entramos na intimidade de Cynthia e permitimos, com isso, que ela nos explique seus dramas e seus pontos de vista, deixamo-nos levar pelo mesmo tipo de batida que marca o ritmo dos romances desta natureza. David - apesar de ser homem e protagonista - fica na sombra diante da força da subjetividade dramática de uma "mulher de gênio". O pensamento organizado, aliado à estrutura dramática dos capítulos em que a moça toma a palavra, contribui para este efeito. Compreendemos em que medida o movimento entre sentimento e pensamento dá sentido ao discurso do personagem, ao mesmo tempo em que posiciona o romance dentro de uma constelação de outros textos.

Se o gênio se sobressai na caracterização de Cynthia, é o diafragma que parece predominar num primeiro contato com os capítulos em que fala Camilla. Em oposição à eloqüência da primeira, a expressão extrema do sentimento implica, em Camilla, a impressão de uma quase anulação da eficácia do verbal. A moça ameaça algumas vezes

\footnotetext{
${ }^{120}$ As idéias desenvolvidas neste trecho foram inspiradas por CHAUÍ, Marilena. "Prefácio", in: MATTOS, Franklin de. A Cadeia Secreta. Diderot e o Romance Filosófico. São Paulo: Cosac \& Naify, 2004. p. 9.

${ }^{121}$ CHAUÍ, Marilena. op. cit., p. 9.
} 
interromper sua narrativa com "Sobs" e se desculpa pela incapacidade de relatar, com palavras, exatamente o que viveu e sentiu - "I am very certain no Words can express it so strongly as your own Imagination will suggest it to you"122.

Esta característica fez com que o personagem se tornasse menos atraente para a crítica feminista, que se entusiasmou bem mais com as respostas diretas de Cynthia. No entanto, o que se encontra na constituição do personagem Camilla não é a ausência do discurso articulado, e sim uma combinação diferente entre pensamento e sentimento. A moça inicia sua narrativa afirmando: "The task I have undertaken, Sir,[contar sua história] cannot be performed without Interruptions from the Remembrance of past Sorrows; but I make no question, you will be so good as to pardon my Weaknesses" 123 (DS, 134).

Depois de explicar suas origens, Camilla conta o episódio da morte de sua mãe num incidente "which has never been out of my Thoughts twenty-four Hours since it happened, and which I can never mention without the most piercing Grief" ${ }^{124}$ (DS, 135): durante uma caminhada, a mãe pisa num espinho e acaba falecendo alguns dias depois, em conseqüência da inflamação. Todo o episódio - do acidente à morte - é relatado em detalhes e a narração é profundamente marcada pela expressão dos sentimentos mais profundos do personagem - o tom lacrimejante transborda em cada frase.

Mas a razão logo entra em cena para balancear a explosão de sentimentos. Camilla reconhece a morte da mãe como o acontecimento que ocasionou a reviravolta em sua vida: "Thus I lost the best of Mothers, and from her Loss I date all the Miseries of my Life" ${ }^{125}$ (DS, 137). A partir deste momento, a narrativa de Camilla se organiza de modo semelhante à de Cynthia. Assim é que, no capítulo décimo do segundo livro, a moça explica a David que seu pai, tendo se apaixonado por Livia, convenceu a filha de que o

\footnotetext{
122 [tenho certeza de que nenhuma palavra pode expressá-lo tão fortemente como a sua imaginação lhe poderá sugerir]

${ }^{123}$ [A tarefa que assumi, senhor, não pode ser cumprida sem interrupções da lembrança de sofrimentos passados; mas não duvido que o senhor será bom e perdoará as minhas fraquezas.]

${ }^{124}$ [nunca ficou longe de meus pensamentos por mais de vinte e quatro horas por dia desde que ocorreu, e que não posso mencionar sem o mais terrível sofrimento]

${ }^{125}$ [perdi a melhor das mães e a partir desta perda eu dato todas as misérias de minha vida]
} 
casamento seria a melhor opção para ele e sua família. Camilla nem hesita em aceitar a escolha do pai, mas não sem o seguinte comentário - a posteriori, claro:

(...) I have often reflected, that it is a great Misfortune that a good Understanding, when it is accompanied with a very strong Imagination, only makes People judge right, where their own Inclinations are not concerned; but when once any violent Passion interposes, it serves only to hide and gloss over all bad Consequences that attend the Gratification of that Passion, and removes Difficulties out of the way, to a Man's own Destruction; which a Person of less Sense, and a cooler Fancy, would never be able to accomplish: for Strength of either Mind or Body, is useful only as it is employed ${ }^{126}$. (DS, 140)

Camilla expõe nesta passagem um raciocínio articulado que envolve a discussão sobre a relação do indivíduo com sua compreensão do mundo, sua imaginação, seu discernimento, e com o quanto o desejo pode interferir com este último - a ponto de fazêlo tornar-se apenas mais um instrumento para a satisfação das "inclinações"... A mocinha que se julga incapaz de relatar sua história sem interrompê-la com soluços chega, ao mesmo tempo, a este grau de reflexão sobre os caminhos que tomam razão e sentimento num indivíduo tomado pela paixão. $\mathrm{O}$ mecanismo de construção do personagem assemelha-se àquele que pudemos identificar em Cynthia, ainda que o resultado não seja o mesmo.

A relação da moça com a madrasta vai se complicando, até o momento em que Camilla decide começar a olhar a mulher do pai como esta de fato se comportava diante dos dois irmãos - e não mais com a parcialidade que o estatuto de Livia exigia. $\mathrm{O}$ comportamento desta só parecia facilitar a tarefa, pois suas atitudes eram exclusivamente controladas pela paixão: Camilla relata a David como a madrasta gastava todo o dinheiro do pai, fingia agradar os dois irmãos diante dele, simulava uma generosidade que não tinha. Camilla indica que Livia possuía, por dentro, uma imagem oposta à sua aparência.

\footnotetext{
${ }^{126}$ [eu já refleti muitas vezes que é uma grande desgraça que uma boa capacidade de compreensão, quando é acompanhada de imaginação fértil, somente faça as pessoas julgarem corretamente quando suas próprias inclinações não estão envolvidas; mas quando qualquer paixão violenta se apresenta, serve somente para esconder e dissimular todas as más conseqüências que resultam da gratificação daquela paixão, e remove dificuldades do caminho, para a autodestruição de um homem; o que uma pessoa de menos sabedoria, e gostos mais brandos, nunca conseguiria fazer: pois a força da mente ou do corpo só é útil quando é utilizada.]
} 
Para expor tal idéia, o personagem utiliza uma "visão" publicada nos números 100-102 do Tatler:

I often thought, could she have beheld herself in the Goddess of Justice's Mirror of Truth, as it is described in that beautiful Vision in the Tatler, she would have loathed and detested, as much as now she admired herself ${ }^{127}$. (DS, 143)

E completa: nem uma metamorfose de Ovídio teria sido tão surpreendente para Livia do que ter diante de si o tal "Espelho da Verdade". O jogo com as imagens conflito entre a auto-imagem e a imagem pública - reforça um aspecto que se revelará de modo mais contundente nos capítulos episódicos. Já existe uma imagem de si mesmo que cada indivíduo carrega, e esta não se conjuga necessariamente com o papel que este mesmo indivíduo deve cumprir no jogo social.

A imagem e a transformação desta, motivada pelas paixões, são motivos de constante reflexão para Camilla. Em outra ocasião, ela analisa o comportamento deliberadamente tendencioso de seu pai - na direção de Livia -, procurando mais uma vez compreender o efeito de cegueira que as paixões provocam nos homens. Se a mulher revela-se boa, então a cegueira pode ser benéfica. Caso contrário, as conseqüências podem ser terríveis, podendo levar até mesmo à destruição do apaixonado. Nesta situação, continua Camilla, um homem perde seus amigos, se afasta dos que lhe querem bem e procura, sempre, esquivar-se do motivo real destas rupturas.

Nesta lógica, é Otelo que aparece como a referência que ajuda a explicar o comportamento do pai diante de paixão cega por Livia. $\mathrm{Na}$ impossibilidade de enxergar os fatos, "he will (...) find he has roused a Fury, which 'Poppies, nor Mandragora, nor all the drowsy Syrups of the World, can medicine to sweet Sleep again,", ${ }^{28}$ (DS, 151).

\footnotetext{
${ }^{127}$ [Eu pensei com freqüência que se ela tivesse se visto no Espelho da Verdade da Deusa da Justiça, como está descrito naquela bela visão no Tatler, ela teria tido aversão de si mesma, tanto quanto hoje ela se admira.]

${ }^{128} \mathrm{O}$ trecho acima em negrito não corresponde exatamente ao original de Shakespeare. Na cena III do ato III, Iago diz a Otelo já mordido pelos ciúmes: "Look, here he comes! Not poppy, nor mandragora / Nor all the drowsy syrups of the world / Shall ever medicine thee to that sweet sleep / Which thou ow'dst yesterday" [Vejam, aí vem ele! Nem papoula, nem mandrágora, nem mesmo todos os xaropes soporíferos do mundo terão o poder de medicar-te na busca daquele doce sono de que desfrutavas ontem.] The
} 
Do mesmo modo, Otelo reaparece na última briga entre madrasta e enteada, quando o pai se transforma fisicamente - "the (...) deceived Man stared with Fury, his Eye-balls rolled, and like Othello, he bit his nether Lip with Fury" (DS, 153) ${ }^{129}$ - antes de agredir a filha. Assim como vimos em Cynthia, Camilla faz uso de um repertório que está a serviço da expressão organizada de sua subjetividade, dissimulando nesta as lições morais que interessa à autora fazer passar.

Diderot identifica, em seu "Elogio a Richardson", uma armadilha sutil e fundamental colocada ao leitor pelo autor de Clarissa. Dentro da perspectiva do grande debate sobre a relação conflituosa entre romance e moral, Diderot observa em Richardson um continuador dos grandes moralistas, com uma diferença que muda tudo: ao invés da moral em "máximas", o romancista inglês oferece ao seu público a moral "em ação". Isto significa que, no lugar do conceito abstrato, temos diante dos olhos uma "imagem sensível”, pessoas poderiam existir de fato - "aquele que age, nós o vemos, colocamo-nos em seu lugar, ou a seu lado"130.

As verdades abstratas são assim transferidas para "as zonas profundas da sensibilidade", o que resulta, para os leitores, num efeito bem mais imediato do que aqueles expressados nos preceitos morais em máximas. Através da experiência da sensibilidade alheia, temos a sensação de equivalência: uma equivalência nas emoções que vai implicar equivalência nas condutas. Estabelece-se por estes meios um vínculo indissociável entre leitor e personagem.

Este vínculo, no entanto, pressupõe auto-reconhecimento, identificação, ver a si próprio no discurso e nas experiências do personagem. Para Diderot, isto significa entregar-se, sem impaciência, ao tempo do romance - gênero criticado, no caso de

Complete Works of William Shakespeare. New York: Gramecy Books, 1975. p. 1133; Otelo. Porto Alegre: L\&PM Pocket, 1999. p. 95. A tradução é de Beatriz Viégas-Faria.

\footnotetext{
${ }^{129}[(\ldots)$ o homem enganado olhou com fúria, seus olhos revirados, e, como Otelo, mordeu o lábio inferior com fúria]

130 "Elogio a Richardson”, in: Guinsburg, J. (org.) Diderot. Obras II. Estética, Poética e Contos. São Paulo: Editora Perspectiva, 2000. p. 16. Ver também ensaio de Franklin de Matos, "Moral em Exercícios: Elogio a Richardson", in: MATOS, Franklin de. Op. cit., p. 73-94. Franklin de Matos inspirou-se, por sua vez, em Jacques Chouillet, La Formation des idées esthétiques de Diderot. Paris : Armand Colin, 1973.
} 
Richardson, por suas "delongas". Significa entregar-se, ainda, a essa "multidão de pequenas coisas"131 que, juntas, compõem a ilusão dramática. Para Diderot, Richardson não nos "transporta em absoluto a países afastados, (...) não se perde jamais nas regiões do feérico. O mundo em que nós vivemos é a cena; o fundo de seu drama é verdadeiro; suas personagens têm toda a realidade possivel; suas figuras são tomadas do âmbito da sociedade; (...) as paixões que ele pinta são tais como eu as experimento em mim" "132.

Interessa, assim, observar como, tanto em Cynthia quanto em Camilla, a preocupação com os pormenores - a tal "multidão de pequenas coisas" a que se refere Diderot - alimenta este conjunto. É indício de uma busca pela articulação orgânica entre sentimento e pensamento, entre estrutura dramática e conteúdo moral, o fato de que tanto os detalhes relatados por Cynthia sobre sua vida com Lady -----, quanto as minúcias do episódio da morte da mãe de Camilla não sejam incompatíveis com os julgamentos e referências feitas pelos personagens.

Entendemos assim que, no romance de Sarah F., os personagens Cynthia e Camilla são construídos em acordo com os "princípios" apontados por Diderot na prosa de Richardson. Em ambos os casos, o leitor entra em contato com as emoções e experiências das duas moças, estabelecendo assim um vínculo estritamente dramático com elas. Trata-se, igualmente neste caso, da moral "em ação". O que diferencia David Simple dos romances richardsonianos, no entanto, é a inclusão do pensamento articulado como parte integrante da subjetividade. A moral aparece assim mascarada pelo pensamento organizado e se articula tanto na ação dramática quanto nas reflexões "filosóficas" dos dois personagens femininos.

Enraizando a experiência das duas mulheres num terreno comum ao dos leitores tanto em equivalência de emoções, quanto em equivalência de referências morais e “intelectuais" -, é definido o vínculo com o público. Mas o narrador vai além. Já comentamos anteriormente como este estabelece, no início do romance, os destinatários a que se dirige: "the polite World". O termo "politeness" (polidez) ganha importância

\footnotetext{
${ }^{131}$ Diderot, Denis. op. cit., . p. 20.

${ }^{132}$ Diderot, Denis. op. cit., . p. 17.
} 
crescente na Inglaterra do século XVIII para identificar uma série de comportamentos sociais e culturais ${ }^{133}$.

Trata-se, primeiramente, de uma designação de classe: o indivíduo "polite" era visto como alguém cujas origens, posição e comportamento se referiam necessariamente ao que se costumava denominar "gentlemanliness". Além disso, o termo servia para definir um tipo específico de comportamento no trato social - o controle da técnica, ou da arte da conversação. Era utilizado também para identificar uma abordagem precisa do conhecimento e da estética: o "polite learning” tinha seus conteúdos específicos (a moral, a política e a literatura clássicas). Classicismo e "stylistic politeness" (polidez estética) apareciam estreitamente relacionados nos textos dos defensores desta nova "atitude" "ancient writings were said to be the epitome of politeness"134.

$\mathrm{Na}$ narrativa de Camilla, a moça tem o cuidado de diferenciar a verdadeira "politeness" do comportamento falsamente "polido". E explica: "she [a madrasta Livia] valued herself much on her Politeness: and I have observed several People value themselves greatly on their own good Breeding, whose Politeness consists in nothing more, than an Art of hurting others, without making Use of vulgar Terms" ${ }^{135}$ (DS, 152). O lado perverso da polidez aparece aqui sob a forma do domínio de uma linguagem específica e de seu uso para fins pouco nobres. Mais uma vez, no discurso de Camilla, é exposto o conflito entre a auto-imagem e a imagem pública como marca do indivíduo que convive em meios sociais favorecidos.

De todo modo, se as características já mencionadas funcionavam para identificar o "gentleman" típico, os princípios definidores deste comportamento sócio-cultural se espalhavam entre os estratos médios da sociedade. Novamente Addison e Steele são vistos como responsáveis, em grande parte, pela popularização dos valores da

\footnotetext{
${ }^{133}$ Utilizei aqui informações de KLEIN, Laurence E. Shaftesbury and the culture of politeness. Moral discourse and cultural politics in early eighteenth-century England. Cambridge: Cambridge University Press, 1996.

${ }^{134}$ [os escritos antigos eram tidos como o epítome da polidez.] Addison, em A Discourse on Ancient and Modern Learning (1734), in: KLEIN, Laurence E., op. cit., p. 7.

${ }^{135}$ [ela se valorizava por sua polidez: e eu já observei muitas pessoas se valorizando bastante por sua educação, cuja polidez consiste somente da arte de ferir os outros, sem utilizar termos vulgares.]
} 
"politeness" - apresentando as coffeehouses como os lugares em que se discutiam e se praticavam os comportamentos "polidos". Tanto nos salões como nas coffeehouses, ser "polido" significava compartilhar estes conhecimentos e atitudes. O narrador de Sarah Fielding pressupõe que seus leitores fizessem parte deste grupo e a construção de seus personagens femininos parece realizar-se com base neste pressuposto.

No caso de Isabelle, a amiga francesa de Cynthia, a situação se complica, ao menos aparentemente. Como já foi dito, o personagem entra na narrativa num momento em que David já havia encontrado seus amigos. Ela também não permanece na história, está apenas de passagem. Muito se perguntou sobre o interesse desta narrativa - a mais longa das três, aliás - que interrompe o périplo de David e sua trupe sem motivos evidentes.

Referimo-nos, acima, ao que chama atenção no personagem logo de início: tratase de uma francesa que viveu, dos cinco aos quatorze anos, isolada num convento, passando o tempo com suas companheiras em "innocent Amusements and childish Pleasures" (DS, 196). Aos quatorze anos, portanto, seu pai a chama de volta à casa da família para apresentar-lhe aquele que seria seu futuro marido. Isabelle vem acompanhada de uma companheira de convento, Julie, da qual havia ficado bastante próxima. Começa assim um relato que propulsiona a narrativa de Sarah Fielding num universo bastante diferente daquele em que viviam os outros personagens - e os leitores de David Simple.

Se, do lado inglês, romanesco e o "novo" romance dividiam espaço com cada vez mais igualdade nestes meados do século XVIII, na França o romance estava em situação um pouco diversa. A tradição do romance de amor e de aventuras, herdada das narrativas medievais, ainda deixava lastros mais precisos. Em séria concorrência com Manon Lescaut (1731), do abade Prévost, estava, por exemplo, Polexandre (1619), de Gomberville, que colocava, numa mesma trama, um peruano rei da Pérsia cujas 
experiências conduziam, sucessivamente, da civilização inca ao Senegal, passando por Copenhagen, e por uma dita "Île Inaccessible"136.

A circulação de romances romanescos franceses em território inglês não devia ser insignificante: basta imaginar que, logo no início do século XVIII, conta-se com a publicação de um número superior a 230 romances na França, contra um pouco mais de 60 na Inglaterra ${ }^{137}$. O percurso do romance neste país ajuda a informar sobre as condições em que seus habitantes entraram no mundo moderno - condições algo diferentes das inglesas. Além de ser necessário o privilégio real para que um livreiro pudesse publicar oficialmente, a Coroa contava com uma equipe numerosa de censores - sem mencionar a proibição pura e simples da publicação de romances entre 1737 e $1738^{138}$.

A grande maioria das narrativas francesas de fins do século XVII, início do XVIII, tinha como base os gêneros pastoral, barroco, ou heróico, fontes de puro romanesco; muito do que foi produzido ali - incluindo imitações - seria rapidamente traduzido para o inglês com o objetivo de suprir um mercado consumidor em crescimento e para o qual não existia censura. Não por acaso, Henry Fielding lembra, em seu Prefácio a Joseph Andrews, os "voluminous Works called Romances, namely, Clelia, Cleopatra, Astraea, Cassandra, the Grand Cyrus, and innumerable others"139.

E, se os ingleses tinham, nos meios intelectuais de além Mancha, a reputação de serem um povo "livre", habitando uma terra de progresso e de justiça, a imagem da

\footnotetext{
${ }^{136}$ Ver COULET, Henri. Le Roman Jusqu’à la Révolution. Paris : Armand Colin, 1991.

${ }^{137}$ MONTANDON, Alain. op. cit., p. 7. Montandon afirma que esta era a diferença entre o número de romances publicados na França e na Inglaterra de 1700 a 1719.

${ }^{138}$ O privilégio era uma permissão do rei oferecida a poucos livreiros - na cidade de Lyon, por exemplo, havia 28 impressores-livreiros em 1636; o número cai para $12 \mathrm{em} \mathrm{1735.} \mathrm{A} \mathrm{Coroa} \mathrm{tinha} 120$ censores por volta de 1760, quando contava com apenas 10, um século antes. Ver a este respeito FAVRE, Robert (org.). La Littérature Française. Histoire et Perspectives. Lyon: Presses Universitaires de Lyon, 1990. pp. 117147.

${ }^{139}$ [as obras volumosas chamadas de romances, a saber, Clelia, Cleopatra, Astraea, Cassandra, o Grand Cyrus e muitas outras.] FIELDING, Henry. Joseph Andrews and Shamela. Oxford: Oxford University Press, 1980, p. 3. A nota que acompanha a referência feita por H. Fielding em seu prefácio explica que os romances citados eram narrativas francesas "de longue haleine" - literalmente, que exigem muito fôlego do leitor -, traduzidas para o inglês no século XVII. De fato: Clélie (1654-60) e Artamène, ou le Grand Cyrus (1649-53), de Mme. De Scudéry, têm 10 volumes cada; Cassandre (1642-45) também tem 10 volumes, e Cléopatre (1647-58), doze - ambos escritos por Gautier de la Calprenède. Vale notar que H. Fielding afirma que estes textos não continham quase nenhuma instrução ou divertimento.
} 
França acabava por se construir no reverso da moeda. São notórios o espanto e a admiração de Diderot, Voltaire, Prévost - e tantos outros seus contemporâneos - com os costumes, a organização política e econômica da Inglaterra. Numa de suas Lettres Philosophiques, Voltaire deixa claro em que medida o torpor absolutista carregava, para ele e outros franceses que tinham contato com a Inglaterra, o fardo do atraso:

En France, est marquis qui veut; et quiconque arrive à Paris du fond d'une province avec de l'argent à dépenser et un nom en $a c$ ou en ille, peut dire: Un Homme comme moi, un homme de ma qualité, et mépriser souverainement un négociant. Le négociant entend lui-même parler si souvent avec dédain de sa profession qu'il est assez sot pour en rougir ; je ne sais pourtant lequel est le plus utile à un État, ou un seigneur bien poudré qui sait précisément à quelle heure le roi se lève, (...) ou un négociant qui enrichit son pays (...) et contribue au bonheur du monde ${ }^{140}$.

Mas este atraso significava também, para olhos ingleses, o charme de uma "realidade exótica", bastante diversa da experiência do cotidiano do outro lado do canal da Mancha. As narrativas romanescas podiam funcionar como veículo de contato com este mundo no qual o maravilhoso podia conviver sem maiores conflitos com as representações do universo citadino.

A entrada de Isabelle em David Simple traz ao leitor inglês setecentista a promessa de contato com os ares deste mundo cheio de conventos e freiras, mocinhas inocentes e cavaleiros apaixonados, fugas e viagens a continentes inóspitos. Traz também o atrativo de uma capital cuja reputação passava mais pela diversão descompromissada, aristocrática, do que pela sobriedade puritana e pequeno-burguesa. Alguns elementos da narrativa procuram conduzi-la por este caminho. Assim, com a chegada do irmão de Isabelle - o Marquis de Stainville - à casa paterna, a moça explica:

\footnotetext{
${ }^{140}$ [Na França, qualquer um pode ser marquês; e qualquer um que chegar a Paris, vindo lá do interior, com dinheiro para gastar, e um nome que termine em ac ou ille, pode dizer: um homem como eu, um homem de minha qualidade, e desprezar soberanamente um negociante. O próprio negociante ouve tão freqüentemente falarem com desprezo de sua profissão, que é tolo o suficiente para enrubescer; no entanto, não sei quem é mais útil para um Estado, um senhor bastante aristocrático que sabe precisamente a que horas se levanta o rei, (...) ou um negociante que enriquece seu país (...) e contribui para a felicidade do mundo.] in: http://www.voltaire-integral.com/ , Lettres Philosophiques (Les Lettres Anglaises), Lettre X. Acessado dia 19/06/2006.
} 
I had besides a Dawn of Comfort in the Company of my Brother, who, notwithstanding his Youth, and being a Frenchman, was of so grave and philosophical a Temper, that he having now finished his Studies, like me preferred the enjoying of his own Thoughts in Ease and Quiet, to all the gay Amusements and noisy Pomp which were to be met with in Paris ${ }^{141}$. (DS, 202203)

Paris é a cidade do barulho pomposo, da diversão ligeira, dos homens jovens, elegantes e pouco sóbrios. Este mesmo irmão acaba assassinando - por ciúmes - seu melhor amigo, o chevalier Dumont, numa cena de intensa dramaticidade:

This was no time for Reason to bear any sway; ten thousand tumultuous Passions at once possessed his Soul, and he obeyed the Dictates of his Rage, by suddenly drawing his Sword, and burying it in the Body of the poor, unhappy, injured Dumont ${ }^{142}$. (DS, 245)

A tragédia dos dois amigos é apenas a primeira: Stainville não suporta a culpa e fere-se quase mortalmente com a própria espada; sua mulher, Dorimene - o pivô do assassinato de Dumont - tem um terrível fim, ingerindo o veneno que havia preparado para Isabelle: “(...) she had already revenged me on herself, by swallowing the very Poison she had before prepared for me"143 (DS, 247). Vingança pura, pois Dorimene tinha se apaixonado por Dumont, enquanto este sofria de amores por Isabelle...

A referência à vida mundana parisiense, à paixão e às mortes violentas e trágicas parece colocar esta história no rumo das tramas dos longos romances franceses. Contudo, o personagem Isabelle não corresponde de fato a nada que se assemelhe a tal expectativa.

\footnotetext{
${ }^{141}$ [Eu tinha, além disso, um pouco de conforto na companhia de meu irmão que, apesar da pouca idade e de ser um francês, tinha um temperamento tão grave e filosófico que, tendo acabado seus estudos, como eu, preferia distrair-se com seus próprios pensamentos na calma e tranqüilidade, a todas as alegres diversões e à barulhenta pompa que se encontravam em Paris.]

${ }^{142}$ [Não era o momento para a influência da razão; dez mil paixões tumultuosas possuíram sua alma de um golpe, e ele obedeceu à sua fúria, enterrando sua espada, de repente, no corpo do pobre, infeliz, ferido Dumont.]

${ }^{143}$ [ela já havia me vingado em si mesma, ingerindo o mesmo veneno que havia antes preparado para mim.]
} 
Ela explica, já no início de sua história, a atitude que tomou a respeito do pretendente escolhido pelo pai:

I begged my Father would give me leave to converse with him a little while longer, without being thought for that reason engaged in Honour to live with him for ever: for certainly it is very unreasonable that any Person should be obliged immediately to determine a Point of such great Importance ${ }^{144}$. (DS, 197-198)

O comportamento de Isabelle neste primeiro percalço de sua vida fora do convento teria pouca verossimilhança numa história romanesca de fato. Mais do que discernimento, a moça parece ter iniciativa. Compreende rápido que sua amiga Julie nutria uma paixão secreta por seu pretendente, Monsieur Le Buisson. Prevendo, portanto, que seu casamento com o rapaz ocasionaria grande infelicidade à colega de claustro, Isabelle não hesita em se lançar num plano infalível para uni-los: "I overcame all my Scruples and engaged heartily in it" ${ }^{145}$ (DS, 199). Nada mal para alguém que passara toda a vida em meio a religiosas.

Isabelle atravessa assim o turbilhão de paixões e sofrimentos das pessoas com quem convive, armada exclusivamente do discernimento e iniciativa, tudo muito bem arranjado com o auxílio da reflexão. Em diversas passagens, o personagem só deseja se retirar, "for I was impatient to be by my self, that I might be able at full liberty to make what Reflections I pleased" (DS, 241). Compreende-se, desta forma, que ela perceba o que ninguém parecia notar: "What a Condition I was in! what could I think! My Brother, Dorimene, Dumont, all seemed involved in one common Madness (...)."146 (DS, 243). O controle refletido sobre seus sentimentos e a perspicácia não impedem que Isabelle se deixe confundir, em alguns momentos, pelo jogo das aparências e das paixões. Os

\footnotetext{
${ }^{144}$ [Pedi a meu pai que me desse permissão para conversar com ele um pouco mais, sem que pensasse que eu estaria por isso comprometida com ele para sempre: pois certamente é muito pouco razoável que qualquer pessoa seja imediatamente obrigada a decidir um assunto de tão grande importância.]

145 [Venci todos os meus escrúpulos e me engajei de coração naquilo.]

${ }^{146}$ [pois eu estava impaciente para ficar sozinha, para fazer, em total liberdade, as reflexões que quisesse.]; [em que condição me encontrava! O que poderia pensar! Meu irmão, Dorimene, Dumont, todos pareciam envolvidos numa mesma loucura comum (...).]
} 
mecanismos deste jogo - que remete ao trato social - se revelam para a moça num rodamoinho de acontecimentos graves e irreversíveis.

O episódio de Isabelle dispensa as menções a referências culturais comuns entre os ingleses - nada de Pope, Shakespeare ou Steele -, mesmo porque seria pouco verossímil, dentro da lógica do personagem, construí-lo através destes critérios. De todo modo, o que fundamenta a experiência de Isabelle é a articulação do pensamento como expressão da subjetividade e, ao mesmo tempo, como indício do controle sobre as paixões - ponto que tem em comum com Cynthia e Camilla. Neste sentido, a francesa não poderia ser mais inglesa.

A presença destes três "momentos" autobiográficos nas Adventures of David Simple causou bastante estranheza, como vimos, à crítica nossa contemporânea - mas talvez não tanto ao leitor (ou leitora) que teve o romance nas mãos no século XVIII. Parece evidente que, partindo de uma perspectiva que ignora o processo histórico na sociedade e no gênero - e fixando regras artificiais para se decidir o que é e o que não é romance -, os três personagens perdem significado. Por outro lado, ao observarmos a narrativa de Sarah Fielding sob a perspectiva de McKeon - ou seja, como lugar de encontro (ou embate) de diferentes forças narrativas e ideológicas -, compreendemos o interesse da inclusão destes capítulos no corpo do romance.

Parece que, para garantir a transmissão da mensagem, as formas do "ceticismo extremo" - simplificadamente, o modo episódico à la Fielding - não eram suficientes. Para dar sentido à história do herói peripatético, era preciso fazer uso também do modo dramático, pois um acaba contribuindo para que o outro receba conteúdo de verdade. O episódio de Isabelle se encaixa perfeitamente dentro da estrutura episódica - ela é apenas mais uma pessoa que passa pelo caminho de David. Mas garante, ao mesmo tempo, um sentido moral que as peripécias, por si só, poderiam enfatizar pouco. Na mesma lógica aparecem Cynthia e Camilla - sendo que a primeira tem papel ainda mais importante na trama do romance por ser a força reorganizadora do núcleo familiar na segunda fase da história. 
Vale agora observar um pouco o outro lado: a saber, como são estruturados os capítulos "episódicos" das Adventures of David Simple. Procuraremos compreender, primeiramente, o quanto estes se aproximam e se afastam do modelo do romance estruturado em episódios, do qual as obras de Henry Fielding são paradigmas importantes para Sarah F. Em seguida, vale observar em que medida estes capítulos ganham sentido pela co-habitação com as histórias de vida das três moças - ao mesmo tempo em que devolvem significado para estas histórias dentro da estrutura do romance.

\subsection{Caminhar pelas ruas de Londres}

Voltemos às origens: logo no início da história, David Simple se afasta do irmão por causa da herança paterna, mas logo recupera sua fortuna e, como se não bastasse, herda também a fortuna do tio que o acolheu. De posse de todo o dinheiro, David "was at first more unhappy; (...) He had no Ambition, nor any Delight in Grandeur. The only Use he had for Money, was to serve his Friends" 147 (DS, 26). Como não havia amigos em volta a quem o herói pudesse servir, era necessário sair à procura. Começa a se definir aqui o tipo de viagem que protagonista está prestes a iniciar.

A vida reclusa de David havia impedido, até então, que ele se aventurasse pelo mundo. Seu desejo de procurar um amigo verdadeiro se apresenta, primeiramente, de maneira quixotesca - "only as mad as Quixotte himself could be" (DS, 27). No entanto, ao invés de ele ganhar o mundo, a metrópole onde vivia lhe parecia o lugar ideal para tal viagem. Grande como era, Londres apresentaria, sem dúvida, exemplos de todos os tipos humanos possíveis. Depois, em países estrangeiros, "not understanding the Languages so readily, it would be more difficult to find out the Sentiments of others, which was all he wanted to know" 148 (DS, 27). O narrador já marca a importância essencial da

\footnotetext{
${ }^{147}$ [Ficou, de início, ainda mais triste. (...) Pois ele não tinha qualquer ambição, ou deleite na grandeza. $\mathrm{O}$ único uso que faria do dinheiro era servir seus amigos.]

148 [sem entender as línguas tão prontamente, seria mais difícil descobrir os sentimentos dos outros, que era tudo o que ele queria saber.]
} 
conversação como elemento constituinte da trama e do processo das descobertas pelo qual o herói - e o leitor - é conduzido.

Uma viagem pela cidade de Londres era o que bastava a David. Mas ainda havia outra restrição. Se o interesse estava nos sentimentos dos outros, era necessário fazer um percurso diferente daquele esperado dos viajantes, com uma perspectiva também diversa:

(...) not as some Travellers do, to see the Buildings, the Streets, to know the Distances from one Place to another, with many more Sights of equal Use and Improvement; but his Design was to seek out one capable of being a real Friend, and to assist all those who had been thrown into Misfortunes by the ill Usage of others $^{149}$. (DS, 27)

Afastamo-nos assim da expectativa de encontrar, na história de David Simple, algo que se assemelhe aos relatos de viagem - que faziam parte, junto com os romances, das preferências do público leitor setecentista inglês. Esta maneira de organizar a perspectiva não é fortuita. Como indica o narrador, a primeira coisa que ocorre a um homem que está em busca de algo, "is which is the most likely Method of finding it" (DS, 28). A viagem de David está marcada, assim, em sua concepção, pelo método. Este elemento pode passar despercebido numa primeira leitura do romance de Sarah Fielding, mas ganha importância quando colocado em perspectiva em relação a outros romances em que o protagonista se lança em semelhante périplo.

Em comum com outros romances de "viagem", David Simple tem o enredo construído em episódios quase independentes. Porém, o método a que se refere o narrador serve para estabelecer o que sua viagem tem de diverso em relação a outras, de outros viajantes. Não se trata, primeiramente, de uma viagem à la Quixote - a loucura do cavaleiro errante apenas diverte o protagonista de Sarah F. Também não é uma viagem motivada pela condição social do herói. Vimos como a decisão de David de sair em viagem só é tomada depois que ele já retomou sua posição social através da recuperação

149 [não como fazem alguns viajantes, para ver as casas, as ruas, para conhecer a distância entre dois lugares, com muitas outras visões de equivalente utilidade e progresso; seu objetivo era buscar alguém capaz de ser amigo de verdade, e auxiliar todos que tivessem caído na infelicidade por terem sido mal tratados pelos outros.] 
da fortuna do pai. Não há nenhum tipo de risco factual à situação social ou financeira do protagonista na primeira metade da história - a perda do capital e a conseqüente decepção e queda só ocorrerão em Volume the Last.

O que se apresenta, mais precisamente, é uma indagação filosófica. O narrador parece deixar nas mãos do acaso, na surpresa do contato com as pessoas pelo mundo a resolução da questão filosófica que o protagonista se coloca antes de partir. Assim, a viagem de David na primeira parte da história lembra, ainda que à distância, o tom da viagem de Jacques e seu amo no romance de Diderot (publicado postumamente em 1796): “Como se encontraram? Por acaso, como todo mundo. (...) Onde iam? Por acaso sabemos para onde vamos?"150. O que importa é o trajeto em si mesmo, os encontros e as conversas que os caminhos oferecem. O romance de Sarah F. se movimenta, mais uma vez, na direção do tipo de romance que representou, no século XVIII, o romance filosófico.

Dentro desta perspectiva, a cidade de Londres tem papel fundamental no desenvolvimento da trama pelos caminhos do acaso. A escolha de David de circular unicamente pela metrópole já nos indica a importância que a cidade havia adquirido: trata-se de um lugar onde tudo existe, onde se vê de tudo um pouco, todos os tipos de caracteres, todos os tipos de homens e mulheres. $\mathrm{O}$ interesse por este lugar se justifica: a capital era dez vezes maior do que qualquer outra cidade inglesa no mesmo período, e foi o palco central de todas as mudanças fundamentais desde o início do século XVIII na Inglaterra $^{151}$

A cidade crescia em ritmo assustador, impressionando aqueles que observavam e escreviam sobre o fenômeno - especialmente no que se refere à "segregação de classes". De fato, o crescimento urbano era acompanhado de uma separação cada vez mais nítida entre as classes ricas - que passaram a povoar as zonas oeste e norte da cidade - e as

\footnotetext{
${ }^{150}$ [Comment s'étaient-ils rencontrés? Par hasard, comme tout le monde. (...) Où allaient-ils? Est-ce que l'on sait où l'on va?] In : DIDEROT, Denis. Jacques, le Fataliste, Paris : Librairie Générale Française, 1983. p. 13.

${ }^{151}$ Neste trecho utilizamos informações do capítulo 6 do estudo de Ian Watt, “A Experiência Privada e o Romance", in: WATT, Ian. op. cit., pp. 152-180.
} 
pobres - que ficaram com a zona leste. Addison já identificara os resultados deste processo: “(...) os habitantes de St. James, apesar de viverem sob a mesma lei e falarem a mesma língua, são diferentes daqueles de Cheapside" ${ }^{\text {.152. }}$.

O narrador de Sarah Fielding compreende e sinaliza este contorno sócioeconômico que vinha assumindo a cidade de Londres desde sua reconstrução, após o Grande Incêndio de 1666. Deste modo, a romancista desvia levemente do modelo do romance episódico, o qual, desde D. Quixote, lança seu protagonista pelas estradas, no campo, longe das grandes aglomerações que já começavam a se formar. Mais do que isto: observando com cuidado o trajeto de David, é possível identificar que as caminhadas do herói por diferentes regiões da cidade são definidas pelos tipos sociais que deseja encontrar. O narrador nos explica, no início do capítulo IV, por que interessa a David circular por diferentes ambientes:

Our Hero, therefore, began to consider seriously among all the Classes and Degrees of Men, where he might most probably meet with a real Friend. But when he examined Mankind, from the highest to the lowest, he was convinced, that to Experience alone he must owe his Knowledge; for that no Circumstance of Time, Place, or Station, made a Man absolutely either good or bad, but the Disposition of his own Mind; and that Good-nature and Generosity were always the same, tho' the Power to exert those Qualities are more or less, according to the Variation of outward Circumstances. He resolved therefore, to go into all publick Assemblies, and to be intimate in as many private Families as possible $(\ldots)^{153}$. (DS, 28)

O herói imagina poder encontrar generosidade e benevolência em qualquer ambiente; mas sabe, ao mesmo tempo, que a cidade se organiza de modo a separar o "highest" do "lowest". Sabe também que a capacidade de expressar bons sentimentos no contato social vai depender bastante das tais "outward Circumstances". O narrador

\footnotetext{
${ }^{152}$ WATT, Ian. op. cit., p. 155-56.

${ }^{153}$ [Nosso herói, portanto, começou a considerar seriamente, dentre todas as classes e níveis de homens, onde ele provavelmente encontraria um amigo verdadeiro. Mas quando examinou a humanidade, da mais alta à mais baixa, convenceu-se de que só a experiência pode trazer este conhecimento; pois nenhuma circunstância de tempo, lugar, ou posição fazia com que um homem fosse completamente bom ou ruim, exceto a disposição de sua alma; e que boa índole e generosidade eram sempre as mesmas, apesar de a força de exercer estas qualidades ser maior ou menor em função da variação das circunstâncias externas. Ele decidiu então ir a todas as reuniões públicas e tornar-se íntimo de quanto mais famílias pudesse (...).]
} 
reproduz assim, dentro da narrativa, um sentimento que o londrino já devia ter naqueles meados do século XVIII, característico da vida na cidade grande: o ressentimento do conflito entre a proximidade geográfica e a distância social entre pobres e ricos.

Parece evidente que, nestas condições, as regras de convivência social se alterem, adaptando-se à excessiva fragmentação que a cidade grande impõe a seus habitantes. Ao invés da organização estruturada e aparentemente imutável das relações no campo, a vida na metrópole coloca a ênfase nos valores materiais em detrimento de uma visão orgânica da estrutura social. Porém, ao contrário dos personagens de Defoe, que muitas vezes tiram proveito destas circunstâncias - basta pensar nas atividades profissionais de Moll Flanders -, o protagonista de Sarah Fielding acumula decepções.

A cidade não é uma fonte inesgotável de possibilidades de enriquecimento e projeção social, mas um ambiente hostil, mesmo perigoso, no qual impera a solidão e em que cada um se isola - seja por escolha, seja por falta de opção - em seus objetivos egoístas. Assim, cada lugar por onde passa, David procura oportunidades de encontros com indivíduos pertencentes a grupos sociais diferentes e cuja "idoneidade" de sentimentos o narrador decide, através do herói, colocar à prova. Estes lugares carregam significados que adicionam carga a seu sentimento de frustração.

Voltemos ao exemplo da Bolsa de Valores, primeiro lugar visitado por David. A vida de Londres parecia borbulhar em torno dela: em 1739, a cidade tinha um número aproximado de 450 tavernas, a grande maioria localizada nas imediações do RoyalExchange. Este local provocou a admiração de Voltaire - o filósofo se refere a ele como "um lugar mais venerável do que muitos tribunais" 154 - e encarnava, tanto para os estrangeiros quanto para os londrinos, a liberdade econômica que parecia colocar a Inglaterra na dianteira do desenvolvimento do capitalismo europeu.

154 [a place more venerable than many courts of justice]. Voltaire, Lettres Anglaises, in: PORTER, Roy, The Creation of the Modern World. The Untold History of the British Enlightenment, London: W.W. Norton \& Company, 2000. p. 21. 
Contribuía para esta imagem de liberdade a idéia segundo a qual, na Bolsa, homens de crenças e origens diversas podiam conversar pacificamente porque objetivos comuns os faziam superar as diferenças. No entanto, a passagem de David pela Bolsa não lhe deixa lembranças muito louváveis, como já vimos. Ao invés de enfatizar a livre especulação como um elemento positivo, o narrador nos apresenta, pela experiência do protagonista, um Royal Exchange pouco convidativo, no qual a comunicação entre os homens está a serviço de interesses que David não compartilha. Além disso, fica clara a atmosfera de tristeza e medo que, sob a perspectiva do narrador, impera naquele ambiente.

A Bolsa serve ainda como emblema da tríade que, no romance de Sarah Fielding, expõe o lado sombrio do mundo "elegante" da cidade: o teatro, as "polite conversations" e o jogo. Se os três funcionam, de fato, como variações do mesmo tipo de comportamento social - existem regras a serem seguidas, assim como existem ganhadores e perdedores -, é na Bolsa que este teatro-jogo se revela de maneira dificilmente mais reveladora. Também é o lugar onde as palavras, nos diálogos, estão unicamente a serviço das aparências e dos interesses. Daí a reação do herói diante de sua primeira decepção "pública": "David was amazed at such Treachery"155 (DS, 29).

O narrador convida seu leitor, no entanto, a observar mais de perto cada uma das três facetas da vida na cidade. Assim, no capítulo $\mathrm{X}$ do livro primeiro, David e Mr. Orgueil vão ao teatro assistir à nova peça "which he [Mr. Orgueil] heard had made a great Noise in the Town"156 (DS, 67). Antes mesmo de começar o espetáculo, um burburinho se intensifica na sala. Os amigos e inimigos do autor já expressam suas opiniões contra ou a favor do texto e da encenação. $\mathrm{O}$ início da representação não faz diminuir o barulho nem os julgamentos a respeito da qualidade do texto. O resultado é imediato: "the Play was condemned to eternal Oblivion, without having ever been heard" ${ }^{\text {,157 }}$ (DS, 69).

\footnotetext{
${ }^{155}$ [David ficou impressionado com tamanha traição]

${ }^{156}$ [a qual, ele ouviu dizer, tinha feito estardalhaço na cidade]

${ }^{157}$ [a peça foi condenada ao esquecimento, sem nunca ter sido ouvida]
} 
David conversa com um "Gentleman" que havia contribuído claramente para o fracasso da apresentação. Este homem se revela um amigo do autor da peça e explica ao herói os motivos que o levaram a contribuir para a sua condenação: "as I am his Friend, and found it was very bad (...); between you and I, he cannot write at all (...)"158 (DS, 70). Coloca-se aí a lição para David - e para o leitor -, num cenário de teatro, das regras do convívio social no mundo "polido".

Mais adiante, David decide observar a vida entre os mais ricos, e, munindo-se de "a fine Coat, a well-powdered Wig, and a Whist-Book"159 (DS, 77), o herói passa algum tempo entre pessoas identificadas como Duchess of ------------, ou Countess of -------------. Os acessórios de que o herói faz uso para adentrar os salões da alta sociedade indicam, mais uma vez, as aproximações entre a vida em sociedade e o teatro, o jogo. As regras do convívio no mundo "polido" dos salões também incluem figurino específico...

A importância do livro de whist se justifica, pois este jogo de cartas - cuja invenção, na Inglaterra, data do século XVIII - era bastante praticado pela sociedade elegante da época. Nestas reuniões, o protagonista observa a repetição de um padrão: "David walked from one to the other, to make what Observations he could; but he found they were all alike"160 (DS, 79). A relação entre jogo, teatro e conversação aparece mais uma vez em comentário do narrador, ressaltando o clima de hipocrisia que se estabelece quando os três se confundem e se misturam na prática social:

Those very People, who, before they sat down to play, conversed with each other in a strain so polite and well-bred, that an unexperienced Man would have thought the greatest Pleasure they could have, would have been in serving each other, were in a moment turned into Enemies (... $)^{161}$. (DS, 79)

\footnotetext{
${ }^{158}$ [como sou seu amigo, e achei que estava muito ruim (...); cá entre nós, ele não sabe escrever (...).]

${ }^{159}$ [um bom casaco, uma peruca com bastante talco, e um livro de whist.]

160 [David foi de uma a outra, para observar o máximo que pudesse; mas descobriu que eram todas iguais.]

${ }^{161}$ [Aquelas mesmas pessoas que, antes de sentar-se para jogar, conversavam umas com as outras num tom tão bem-educado e polido, que um homem inexperiente imaginaria que o maior prazer que elas poderiam ter estaria em servir umas às outras, em um momento transformavam-se em inimigas (...).]
} 
O teatro volta a aparecer no segundo capítulo do livro dois, "Which contains a Conversation" (DS, 82). A conversa acontece na casa de uma Lady, a qual, possuidora de " a great deal of Wit", gostava de compartilhar esta qualidade com alguns amigos. Estão presentes David, Mr. Spatter, além de uma "large Company of Ladies, and two or three Gentlemen" (DS, 82). Neste capítulo, cuja organização na página lembra o texto dramático, os personagens discutem justamente teatro. $\mathrm{Na}$ linha de fogo está Shakespeare, mas também aparecem Dryden, Addison e Lillo. O narrador intervém com uma elucidativa descrição do ambiente:

And now, Reader, if you have lived in the Country, and heard the Cackling of Geese, or the Gobbling of Turkeys, you may have an Idea something adequate to this Scene; but if the Town has been mostly your place of Abode, and you are a Stranger to every rural Scene, what will give you the best Idea of this Conversation is the "Change at Noon, where every one has a particular Business of his own, but a Spectator would find it a very difficult matter to comprehend any thing distinctly ${ }^{162}$. (DS, 85)

Campo e cidade já estão claramente separados na experiência social que o romance procura reproduzir. Além disso, o teatro serve como assunto para que os personagens encenem relações em que não importa o que se diz, mas a posição social de quem fala e de que maneira apresenta suas idéias. $O$ teatro funciona como mote para uma encenação maior, a do contato social baseado na aparência. Deste modo, a idéia de "politeness" se reveste de uma ambigüidade que não deixa de ser irônica: o narrador escolhe dirigir-se ao público "polido" e, ao mesmo tempo, expõe o lado perverso dos comportamentos sociais que as regras da "politeness" acarretam.

Isto posto, compreende-se que, se a cidade é um meio pouco acolhedor, resta ao citadino o refúgio em si mesmo e nas relações pessoais que consegue estabelecer. De fato, o morador da cidade grande tem várias identidades em função do grupo por onde circula, mas não consegue reuni-las nunca numa mesma ocasião:

\footnotetext{
${ }^{162}$ [E agora, leitor, se você já viveu no campo e ouviu o cacarejo dos gansos, ou o gorgolejo dos perus, terá uma idéia adequada desta cena; mas se a cidade foi sua principal morada, e você for um estrangeiro no campo, o que lhe dará melhor idéia desta conversa é a Bolsa ao meio-dia, onde cada um tem um negócio particular para resolver, e um espectador teria sérias dificuldades para compreender algo claramente.]
} 
(...) ele pertence a muitos grupos sociais - de trabalho, religião, família, lazer -, mas nenhuma pessoa isolada o conhece em todos os seus papéis e vice-versa. A rotina cotidiana não propicia uma rede permanente e confiável de laços sociais e, como não existe um forte sentido de comunidade ou de padrões comuns, surge a necessidade de uma espécie de segurança emocional e compreensão que só se pode encontrar na intimidade dos relacionamentos pessoais ${ }^{163}$.

Watt vê em Defoe uma leve referência a esta necessidade de refúgio na intimidade, mas seus personagens ainda sabem tirar proveito das condições de vida na cidade. David Simple parece ser, para o crítico, um romance representativo de uma nova atitude em relação ao anonimato urbano, pois o herói circula triste e sozinho por um ambiente anárquico sem conseguir dar significado às suas experiências. $\mathrm{O}$ mal-estar se assemelha àquele sofrido por Richardson, para o qual o refúgio se materializa na fuga ao subúrbio, solução para tudo o que a cidade representava. Na oposição entre urbano significando o mundo "polido", a vida social, o burburinho das ruas - e suburbano - a proteção do lar burguês em local afastado -, o romancista escolhe o afastamento para construir sua "estufa de sensibilidade".

Da mesma maneira, ainda que David escolha percorrer a grande cidade em busca de amigos, a fragmentação da vida urbana é explicitamente perturbadora para o protagonista. Seu desejo de isolar-se com sua família em algum lugar afastado - projeto que acaba por não se concretizar em Volume the Last - indica a tensão na relação com Londres e vai ao encontro dos ímpetos suburbanos do autor de Clarissa. Porém, David não se isola fisicamente, pelo menos na primeira parte da história. Sua "estufa de sensibilidade" é criada, portanto, através de outros recursos.

Janet Todd procura identificá-los num estudo sobre a sensibilidade e sua expressão nas diferentes produções literárias da Inglaterra setecentista ${ }^{164}$. Dentro desta perspectiva, Todd procura compreender algumas obras do período como manifestações da ideologia do sentimentalismo e da sensibilidade, cujas origens intelectuais, sociais e

\footnotetext{
${ }^{163}$ WATT, Ian. op. cit., p. 161.

164 TODD, Janet. Sensibility. An Introduction. London: Methuen, 1986.
} 
econômicas ela procura determinar. Sua análise tem o mérito de colocar estes romances dentro de uma perspectiva histórica, indicando que as produções literárias ganham sentido quando vistas como parte integrante de uma rede de relações econômicas, sociais e intelectuais.

The Adventures of David Simple aparece aqui como parte do estudo dedicado à categoria de personagem denominada "man of feeling", ou seja, aquele "who has, in an unfeeling world, avoided manly power and assumed the womanly qualities of tenderness and susceptibility but who cannot be raped and abandoned" ".65. Se Clarissa estabelecera o padrão da "woman of sensibility", a literatura "lacrimejante" sempre procurou encontrar o seu equivalente do sexo masculino. Todd explica que Richardson ainda não havia conseguido dramatizar este modelo a contento ${ }^{166}$, e começaram a aparecer romances que procuravam atender à demanda e representar o sofrimento de homens sensibilíssimos num mundo material pouco dado a sentimentalismos.

Ao implicar uma relação entre as obras de Richardson e Sarah Fielding que não parte exclusivamente de dados biográficos dos dois autores, englobando referências que vão além do reducionismo da influência - pessoal ou estética - imediata, Todd aponta caminhos pouco aproveitados por Malcolm Kelsall ou pelas autoras dos ensaios feministas discutidos anteriormente. David Simple estaria assim vinculado aos romances de Richardson, mas não somente a estes. Todd procura estabelecer uma "constelação" de textos que inclui os romances de ficção sentimental descendentes da literatura popular, as histórias exemplares e as anedotas de Addison e Steele no Spectator. Assim, o paralelo com os periodistas é novamente inevitável. Se os dois publicam algo como:

\footnotetext{
${ }^{165}$ [que, num mundo insensível, evitou o poder masculino e assumiu as qualidades femininas de ternura e susceptibilidade, mas que não pode ser violentado e abandonado.] TODD, Janet. Sensibility. An Introduction. London: Methuen, 1986. pp. 88-89.

${ }^{166}$ Mesmo com Sir Charles Grandison (1753-54), a missão não seria inteiramente cumprida: "Since he is a man of power, his sensibility and virtue are not in opposition to society [como em Clarissa] but combined with it; there is therefore essentially no story and Richardson is caught in the narrative problem (...) of how to keep together the heroic social qualities and Christian sensibility". [Já que ele é um homem poderoso, sua sensibilidade e virtude não estão em oposição à sociedade, mas combinam com esta; portanto, essencialmente não há história e Richardson se viu encurralado neste problema narrativo (...) sobre como apresentar em conjunto as qualidades sociais heróicas e a sensibilidade cristã.] In: TODD, Janet. op. cit., p. 69.
} 
There is a Call upon Mankind to value and esteem those who set a moderate Price upon their own Merit; and Self-denial is frequently attended with unexpected Blessings, which in the End abundantly recompense such Losses as the Modest seem to suffer in the ordinary Occurrences of Life. ${ }^{167}$

Sarah Fielding não deixa a desejar:

(...) no Circumstance of Time, Place, or Station, made a Man absolutely either good or bad, but the Disposition of his own Mind; and (...) good-Nature and Generosity were always the same, tho' the Power to exert those Qualities are more or less, according to the Variation of outward Circumstances. (DS, 29) 168

Deste modo, David Simple teria encontrado seus "pares" na literatura da época, formando um conjunto no qual Todd coloca ainda romances mais tardios como $\mathbf{A}$ Sentimental Journey (1767), de Laurence Sterne, e The Man of Feeling (1771), de Henry Mackenzie. No que se refere à caracterização, Todd observa elementos que aproximam o protagonista de Sarah Fielding dos protagonistas destes romances sentimentais. Explica que David Simple (assim como o herói de H. Mackenzie) é uma alma "shaftesburiana" ${ }^{169}$ abandonada num mundo materialista e "hobbesiano", que chega ao final de suas aventuras sem que a experiência lhe tenha provocado qualquer tipo de mudança essencial.

\footnotetext{
167 [(...) Há uma necessidade na humanidade de valorizar e estimar aqueles que dão algum valor a seu próprio mérito; e a abnegação é freqüentemente recebida com bênçãos inesperadas, as quais, por fim, recompensam largamente as perdas que (o indivíduo) modesto parece sofrer nos fatos cotidianos da vida.] Fonte: The Spectator, Volume 2, London, 1711. p. 12. http://www.gutenberg.org/, acessado em $29 / 06 / 2005$.

${ }^{168}$ [Nenhuma circunstância de tempo, lugar, ou situação faria um homem ser completamente mau ou bom; exceto a disposição de sua mente; e (...) a natureza boa e a generosidade são sempre as mesmas, ainda que o poder de exercer estas qualidades seja maior ou menor, de acordo com a variação das circunstâncias externas.]

$169 \mathrm{O}$ adjetivo faz referência a Anthony Ashley Cooper, $3^{\text {rd }}$ earl of Shaftesbury (1761-1713). Teve participação ativa na vida parlamentar inglesa até 1702, quando se afastou da política por problemas de saúde. A partir daí, dedicou-se principalmente à filosofia moral e estética. Seus escritos estão reunidos em Characteristicks of Men, Manners, Opinions and Times (1711; edição revisada publicada postumamente, em 1714).
} 
Como homem sentimental, David prefere agir por compaixão ao invés de seguir princípios. Sua relação com o dinheiro também é mediada pelo sentimento. Segundo Todd, o personagem condena a ordem capitalista e não compactua com ela - o que quer dizer, por exemplo, que não aceita vender sua força de trabalho. Sua benevolência e sensibilidade dão o tom em todas as suas atitudes e reações; as lágrimas são expressão física de seu sentimentalismo e de seu sofrimento diante da desgraça alheia. David entra na linhagem de homens como sir Charles Grandison, os quais, na falta de um conflito que coloque sua virtude à prova na esfera sexual (como ocorre com Pamela ou Clarissa), precisam ter a virtude testada através de outras situações - como a pobreza.

O ensaio de Todd identifica, em David Simple, as linhas gerais de uma tendência que se verifica em outros romances e diferentes textos de meados até fins do século XVIII. No entanto, sua análise não chega a apontar, dentro do romance de Sarah Fielding, traços estruturais que exponham a visada sentimentalista. Permanece a dúvida sobre os recursos narrativos que, de fato, organizam a expressão do sentimento na estrutura do romance.

Parece-nos que o primeiro deles - o que chama mais atenção - é a narração autobiográfica que, como vimos, interrompe a sucessão episódica. David está um dia caminhando pela Strand, quando observa um carpinteiro e decide segui-lo até sua casa. $\mathrm{Na}$ seqüência, o narrador apresenta duas histórias "exemplares", que funcionariam bastante bem na estrutura de um manual de conduta - no estilo dos que se encontravam facilmente na época. De um lado, a má esposa - preguiçosa e vaidosa, passava o dia inteiro na cama - que o marido carpinteiro amava intensamente. Do outro, Molly, esposa de um amigo deste mesmo carpinteiro.

O comportamento de Molly era o extremo oposto daquele da má esposa: era trabalhadora, virtuosa e obediente. No entanto, sofria as conseqüências da pobreza e dos maus tratos recebidos do marido. Antes da entrada de Cynthia no romance - ou seja, antes da primeira "série" de capítulos dramáticos -, o leitor tem acesso ao relato, em primeira pessoa, da vida de Molly (livro 1, capítulo 8): “As you seem, Sir, so desirous of 
knowing my Misfortunes, I cannot refuse complying with your Request" ${ }^{\prime 170}$ (DS, 53). Este pequeno "momento autobiográfico" anuncia as séries de capítulos que virão mais adiante - com os relatos de Cynthia, Camilla e Isabelle.

Ao mesmo tempo, deixa vislumbrar, no processo de feitura do romance, a dificuldade da autora de dar sentido de totalidade utilizando-se exclusivamente da técnica do modelo episódico. A experiência urbana era fragmentada e por demais convencionalizada para possibilitar uma compreensão plausível de si e do mundo. Impõese então a presença da expressão da subjetividade. Ao invés de ser percebida como “defeito", a mudança de ritmo - ou a descontinuidade - aqui expressada oferece à crítica uma oportunidade de observar como se sedimentam, na forma, conteúdos históricos e sociais. Funciona também como indício da dinâmica produzida dentro do romance de Sarah Fielding, com o modelo dramático enriquecendo de sentido o modelo episódico e vice-versa.

Um outro aspecto funciona ainda no sentido de amarrar a trama de maneira indelével aos fios da sensibilidade. Observemos com mais cuidado a figura do narrador. No capítulo 1 (Livro 1), ele declara, como vimos, que contará o que ouviu do próprio David, e indica que é ele o grande "mentor" desta narrativa. Já mencionamos como, ao longo do romance, este narrador aparece para dar sua opinião ("For though a man's disposition is not naturally bad, yet it is not quite certain that he will have Resolution enough to resist a Woman's continual Importunities" "171, DS, 13); para citar algum autor de sua predileção ("So true is that Observation of Shakespear's, 'When the Mind is free, the Body is delicate",172, DS, 19); ou para anunciar suas "decisões" ("And there for some time I will leave him to his own private Sufferings" $" 173$, DS, 20).

\footnotetext{
${ }^{170}$ [Como o senhor parece bastante desejoso de escutar os meus infortúnios, não posso me recusar a satisfazer seu pedido.]

${ }^{171}$ [Pois apesar da disposição de um homem não ser naturalmente má, ainda assim não é seguro que ele tenha resolução suficiente para resistir às impertinências contínuas de uma mulher.]

172 [Tão verdadeira é aquela observação de Shakespeare, 'quando a mente está livre, o corpo fica frágil'”]

${ }^{173}$ [E vou deixá-lo por algum tempo aí, com seus sofrimentos íntimos]
} 
Estas intervenções aproximam nosso narrador do célebre "narrador intruso" que o irmão de Sarah F. formalizou posteriormente e com mais clareza em Tom Jones, mas que já se anuncia em Joseph Andrews ou Jonathan Wild. No entanto, as semelhanças escondem uma diferença fundamental. Como já foi dito, o narrador de Henry Fielding é uma instância que distancia o leitor da ilusão ficcional, procurando lembrá-lo constantemente de que está diante de uma história inventada - e armando a impressão de verossimilhança através de outros critérios.

Esta resposta formal contra a "proximidade" quase íntima que se constrói entre leitor e personagem dentro de uma trama essencialmente dramática - lembremos das categorias de McKeon - não vale inteiramente aqui como chave de entrada crítica. Isto porque, apesar das aparências, o que o narrador de David Simple faz é justamente envolver o leitor em seu enredo através da sensibilidade. No início do segundo capítulo do romance, ele explica:

It will perhaps surprize the Reader as much as it did poor David, to find that Daniel, notwithstanding the Appearance of Friendship he had all along kept up with his Brother, was in reality one of those Wretches, whose only Happiness centers in themselves (...). (DS, 11) 174

Ao propor uma espécie de solidariedade de sentimentos com o protagonista David, o narrador das Adventures of David Simple estabelece, sem dúvida, uma relação com o leitor que evidencia a sua interferência no material - afastando-o da ilusão ficcional. Porém, este mesmo narrador implica diretamente o leitor no sistema de valores sobre o qual está construída a narrativa. Está colocado aqui o jogo ambíguo que o narrador ajudará a reproduzir ao longo do relato das aventuras de David.

Nos capítulos em que o romance se desenvolve em ritmo episódico, são inúmeras as ocorrências deste envolvimento que o narrador procura estabelecer entre leitor e personagens. Quando David sai da casa do irmão, depois de ter sido "deserdado", o

\footnotetext{
${ }^{174}$ [provavelmente surpreenderá o leitor, como surpreendeu o pobre David, o fato de descobrir que Daniel, apesar da aparência de amizade que parecia manter em relação ao irmão todo o tempo, era, na realidade, um daqueles desgraçados cuja felicidade se centra somente neles mesmos.]
} 
narrador reconhece: "It would be impossible to describe what he felt when he was alone" 175 (DS, 18). A decepção de David com a filha de um joalheiro com a qual tinha planejado casar-se (e que acaba escolhendo outro pretendente mais velho, porém mais rico) é comentada da seguinte maneira:

(...) And I [narrador] make no manner of doubt, but if she had not met with this Temptation, she would have made a very affectionate Wife to the Man who loved her; (...) And when she had had the Experience, what it was to be constantly beloved by a Man of Mr. Simple's Goodness of Heart, she would have exulted in her own Happiness $(. . .)^{176}$. (DS, 38)

Num dos momentos em que David, diante das decepções constantes, quase decide abandonar sua busca, o narrador assim explica o estado de alma do protagonista:

Poor Mr. Simple began now utterly to despair that he should ever meet with any Persons who would give him leave to have a good opinion of them a Week together $(\ldots)^{177}$. (DS, 49)

O mesmo artifício é utilizado para propor cumplicidade entre o leitor e o próprio narrador. No fim da visita de David a uma das casas onde os convivas jogavam whist, o comentário que se segue é:

And I believe my Reader, as well as myself, is heartily glad to quit a Subject so extremely barren of Matter, as that of Gaming; and into which I would not have entered at all, but that it would have been excluding my Hero from one of the chief Scenes to be viewed at present in this great Town ${ }^{178}$. (DS, 81)

\footnotetext{
${ }^{175}$ [seria impossível descrever o que ele sentiu quando ficou sozinho.]

${ }^{176}$ [E eu não duvido que, se ela não houvesse sofrido esta tentação, teria sido uma esposa muito afetuosa para o homem que a amava (...); e quando ela tivesse passado pela experiência de ser amada constantemente por um homem com a bondade de coração de Sr. Simple, ela teria exultado em sua própria felicidade.]

${ }^{177}$ [O pobre Sr. Simple começou a se desesperar quanto a conseguir encontrar qualquer pessoa da qual ele pudesse ter uma boa opinião pelo menos durante uma semana.]

${ }^{178}$ [Acredito que meu leitor, assim como eu, está bastante feliz de abandonar um assunto tão estéril quanto o jogo, no qual eu não teria entrado de modo algum, se isto não significasse excluir meu herói de uma das cenas principais a serem vistas nesta grande cidade.]
} 
Devagar, o narrador vai indicando a bondade, ingenuidade, sinceridade de coração do "pobre" David, recusando ao leitor a possibilidade de escolher em que medida deve ou não acreditar nisto... E sem deixar nenhuma possibilidade ao leitor de vislumbrar qualquer outra expressão da virtude. Seja através de amostras de valores morais, seja através de um código de conduta compartilhado, o narrador se coloca claramente numa perspectiva instrutiva que obviamente inclui o leitor. E mesmo se este último acaba por se dar conta de que se trata de uma construção, este aspecto fica bastante diminuído diante da importância da "missão ideológica" da qual a narrativa se pretende imbuída. Esta "missão" passa essencialmente pela ideologia da sensibilidade.

Como os mesmos valores são colocados "em ação" nas narrativas de Cynthia, Camilla e Isabelle, a sensibilidade vai se transformando no elo de verossimilhança entre as experiências dos personagens mais "típicos" e a dramaticidade dos depoimentos autobiográficos. O sentimento torna-se, deste modo, um dos grandes eixos de sustentação do romance. Partindo deste pressuposto, cabe avançar mais um passo na análise: se a sensibilidade funciona como "amálgama" entre as diferentes peças desta narrativa, é preciso compreender em que medida este dado reproduz, no interior da obra, um movimento que se encontrava também fora desta, no meio social.

Janet Todd faz breve referência, em seu ensaio, à relação do indivíduo sentimental com o dinheiro, indicando que as relações socioeconômicas têm participação na definição da sentimentalidade dos personagens neste tipo de narrativa. Gillian Skinner, atenta para esta pista, escolhe um recorte mais preciso ${ }^{179}$, se propondo a compreender como a relação entre o sentimento e o dinheiro toma forma em David Simple. H. Fielding e Samuel Richardson são afastados como hipóteses de paradigma; a autora usa como referência para seu ensaio The Fable of the Bees $(1714,1723)$, de Bernard de Mandeville ${ }^{180}$.

\footnotetext{
${ }^{179}$ SKINNER, Gillian. “'The price of a tear': economic sense and sensibility in Sarah Fielding's David Simple", in: Literature and History $3^{\text {rd }}$ series, vol.1 no. 1, Spring 1992. pp. 16-28.

180 Bernard de Mandeville (1670-1733). Médico holandês radicado na Inglaterra, Mandeville publicou textos sobre medicina, como A Treatise of the Hypochondriack and Hysterick Passions (1711, 1730), assim como outros tipos de textos de temática ética: em The Virgin Unmasked $(1709,1714)$, defende
} 
Skinner argumenta que David, ao contrário do que comumente se afirma, não é exatamente um tipo de herói sentimental, mas sim um "Mandevillian fool" - o que, segundo ela, significa dizer a mesma coisa a partir de um outro ponto de vista. Relacionando sensibilidade e economia, a autora pretende demonstrar como o romance de Sarah F. se inscreve num dos debates que caracterizariam o século XVIII inglês, a saber, a dificuldade de se estabelecer, dentro de uma ordem econômica em rápida mudança, o discurso que serviria de justificativa para a relação da classe em ascensão - a burguesia - com o dinheiro. Nesta redefinição de valores, a sensibilidade teria papel fundamental na medida em que se conjuga com generosidade e virtude - segundo ela, caracteristicamente burguesas - em oposição a excesso e extravagância, cuja associação com a aristocracia seria mais freqüente.

Para Skinner, o conflito central se dá entre o comportamento excessivamente "consumista" e dispendioso da aristocracia contraposto a uma ideologia da frugalidade que supostamente deveria nortear a conduta dos setores médios da população. Contra o risco de os representantes desta classe se espelharem nos comportamentos aristocráticos, Oliver Goldsmith aconselharia: "Keep your shop, and your shop will keep you" "181. Este mesmo tipo de mensagem seria reproduzido também em conduct books e, claro, nos romances.

Ainda segundo Skinner, o texto de Mandeville desafia o princípio da frugalidade, posicionando-se, de um lado, contra a idéia shaftesburiana da natureza humana benevolente e, de outro, contra os avisos de moderação dirigidos àqueles indivíduos pertencentes aos setores médios. Sugere, ao contrário, que tudo tem origem no luxo: os "vícios" dos homens estariam na base do sistema econômico, oferecendo desejos a serem atendidos e, portanto, mercadorias a serem vendidas. E isto era positivo para a sociedade como um todo, já que aumentava a riqueza em circulação.

melhor status e educação para as mulheres; An Enquiry into the Origin of Honour (1732) procura estabelecer uma distinção entre auto-estima e amor-próprio; em The Fable of the Bees, or Private Vices, Public Benefits $(1714,1723)$, coletânea que mistura verso e prosa, o autor se dedica a criticar a idéia shaftesburiana de uma natureza humana benevolente, argumentando que a ajuda mútua se baseia no desejo pelo luxo e pelo consumo. In: DRABBLE, Margaret, STRINGER, Jenny. The Concise Oxford Companion to English Literature. London: Oxford University Press, 1990. p. 350.

${ }^{181}$ [Mantenha sua loja, e sua loja o manterá.] 
Apoiando-se em Mandeville e Pope ${ }^{182}$, a autora observa que a presença destas idéias em textos literários e não-literários expunha a demanda por um discurso que conciliasse, dentro da sociedade inglesa, a contradição entre os argumentos tradicionalmente moralistas e um certo "amoralismo econômico" que se verificava na prática das relações. Sua análise de David Simple se propõe, deste modo, a identificar, dentro do romance, um aspecto deste debate público que, segundo ela, foi transferido sem mediação para o interior da narrativa:

In moving, as this essay will do, from describing the general terms of a debate into detailed analysis of an individual novel, such generic influence (whether constraining or liberating) will become apparent. Awareness of its operation is particularly important in cases where one aspect of a debate seems to have been transferred wholesale from a non-literary text into a novel ${ }^{183}$.

Partindo notadamente de um trecho específico do romance em que Cynthia sempre ela - discorre brevemente sobre o luxo e a necessidade ${ }^{184}$, Skinner desenvolve seu

\footnotetext{
${ }^{182}$ O ensaio de Pope é "Epistle to Bathrust", analisado por John Barrel e Harriet Guest, "Of the Uses of Contradiction: Economics and Morality in the Eighteenth-Century Long Poem", in: Felicity Nussbaum and Laura Brown (eds), The New Eighteenth Century: Theory, Politics, English Literature, New York and London, 1987, pp. 121-43.

183 [Passando, como este ensaio se propõe, dos termos gerais de um debate para a análise detalhada de um romance em particular, esta influência genérica (seja limitadora ou liberadora) se fará aparente. A consciência de sua operação é particularmente importante em casos em que um aspecto de um debate parece ter sido transferido em sua totalidade de um texto não-literário para um romance.] SKINNER, Gillian. op. cit., p. 18.

184 "She said, she was considering, amongst the variety of Shops she saw, how very few of them dealt in Things which were really necessary to preserve Life or Health; and yet that those things which appeared most useless, contributed to the general Welfare; for whilst there was such a thing as Property in the World, unless it could be equally distributed, those People who have little or no share of it, must find out Methods of getting what they want, from those whose Lot is to have more than is necessary for them; and, except all the World was so generous, as to be willing to part with what they think they have a right to, only for the pleasure of helping others; the way to obtain any thing from them is to apply to their Passions. As, for instance, when a Woman of Fashion goes home with her Coach loaded with Jewels and Trinkets, which, from Custom, she is brought to think she cannot do without, and is indulging her Vanity with the Thoughts of out-shining some other Lady at the next Ball, the Tradesman who receives her Money in Exchange for those things which appear so trifling, to that Vanity perhaps owes his own and his Family's Support". [Ela disse que estava considerando, dentre a variedade de lojas que via, como poucas vendiam coisas que eram realmente necessárias para preservar a vida e a saúde, e ainda assim, aquelas coisas que pareciam mais inúteis contribuíam para o bem-estar geral; pois enquanto houvesse algo como a propriedade no mundo, a não ser que esta fosse distribuída de maneira igualitária, as pessoas que têm pouco ou nenhuma parte dela devem encontrar maneiras de ter o que querem, tirando daqueles que têm mais do que o necessário; e, a não ser que o mundo inteiro fosse generoso, a ponto de querer abrir mão do que acredita ser seu por direito, somente pelo prazer de ajudar o próximo; a maneira de obter qualquer coisa destes é investir em suas
} 
argumento afirmando que o pragmatismo da personagem é um modelo do novo discurso econômico mandevilliano. Para Skinner, o discurso de Cynthia não encontra eco nos outros personagens e demonstra, assim, a condição marginalizada do protagonista David - que procura justamente alguém que seja generoso por natureza, e não por interesse. É neste sentido que este se caracterizaria como um "Mandevillian fool".

Se The Adventures of David Simple termina "bem" - o duplo casamento entre os quatro amigos "coroa" a busca do personagem -, a situação se deteriora no final de Volume the Last. Para Skinner, este final "infeliz" dado à continuação do romance exemplificaria a dificuldade da coexistência entre uma suposta comunidade sentimental e as relações fundamentalmente comerciais que se definiam naquele momento. Deste modo, Sarah Fielding teria transferido para o romance este debate entre luxo e frugalidade, expondo a fragilidade do discurso sentimental como meio de lidar com relações profundamente marcadas pelo aspecto material.

\section{The Adventures of David Simple e Volume the Last.}

Skinner dá um passo à frente na análise de David Simple ao procurar identificar a ligação entre a expressão da sensibilidade e as relações socioeconômicas - o que Janet Todd apenas insinua. No entanto, seu ensaio perde força argumentativa ao dar preferência ao pressuposto inicial em detrimento da leitura cerrada. Se partirmos da noção da obra literária como "fatura", resultado de operações conjuntas de seleção e montagem, parecenos arriscado propor que teria havido "transferência" para o interior do romance, sem mediação, do debate público provocado pela fábula de Mandeville. Ao contrário, é preciso observar com mais cuidado o papel da Fábula das Abelhas em seu contexto para, em seguida, procurarmos compreender por que processos de mediação o texto de

paixões. Como, por exemplo, quando uma mulher elegante volta para casa com sua carruagem cheia de jóias e bibelôs, sem os quais, por hábito, ela não pode viver, e está alimentando sua vaidade, pensando em brilhar mais do que outra senhora em um baile, o comerciante que recebe seu dinheiro em troca destas coisas que parecem tão fúteis, talvez deva à vaidade seu sustento e o de sua família.] In: FIELDING, Sarah. op. cit., p. 189-190. 
Mandeville entrou na narrativa de Sarah Fielding - e que feições tomou dentro do romance $^{185}$.

É preciso notar, antes de tudo, que a fábula de Mandeville teve recepção extremamente polêmica entre seus contemporâneos, com acusações de imoralidade, tendo mesmo sido proibida pelas autoridades inglesas. Ao mesmo tempo, foi bastante lida e comentada - o que indica que seu conteúdo pode, sem dúvida, ter chegado aos ouvidos de mulheres informadas como Sarah Fielding. Os comentários de Cynthia no trecho de David Simple citado por Skinner são verossímeis sob este ponto de vista - seria perfeitamente plausível que uma moça de seu grupo social tivesse tido acesso às idéias de Mandeville e à polêmica que se seguiu.

As acusações de imoralidade que a Fábula das Abelhas recebeu ficam por conta da idéia controversa da complementaridade que se estabeleceria, em qualquer organização social, entre vício e virtude - o que significava, para alguns, a incitação ao vício. No poema "The Grumbling Hive, or Knaves Turn'd Honest", as abelhas representariam os homens, e a colméia reproduziria o "burburinho" de nossas sociedades - "These Insects lived like Men, and all / Our Actions they perform'd in small". Mandeville descreve a vida naquela comunidade apresentando em tom extremamente irônico as características de alguns ofícios: advogados, médicos, religiosos e soldados. Assim é que, sobre os médicos (Physicians), o leitor encontra a seguinte descrição: "Physicians valued Fame and Wealth / Above the drooping Patient's Health". Na direção dos religiosos, o poema dispara: "Among the many Priests of Jove / (...) Some few were learn'd and eloquent / But Thousands hot and ignorant" ${ }^{\prime 186}$.

Mesmo nas mãos pouco confiáveis destes indivíduos - e exalando vício e crime -, aquela sociedade era rica, respeitada e temida pelas outras colméias: "Thus every Part was full of Vice, / Yet the Whole Mass a Paradice; / Flatter'd in Peace, and Fear'd in

\footnotetext{
${ }^{185}$ Utilizamos como referência para este item os comentários de Fábio Konder Comparato. Cf. Ética. São Paulo: Companhia das Lestas, 2006. pp. Partes III e IV.

${ }^{186}$ [estes insetos viviam como homens / e todas as nossas ações, eles reproduziam em miniatura]; [médicos valorizavam fama e riqueza / em detrimento da vacilante saúde do paciente]; [dentre os muitos sacerdotes de Júpiter / (...) uns poucos eram cultos e eloqüentes / mas milhares, ardentes e ignorantes]. In: http://andromeda.rutgers.edu/, acessado dia 20/06/2006.
} 
Wars / They were th'Esteem of Foreigners, / And lavish of their Wealth and Lives, / The Balance of all other Hives" ${ }^{\prime 187}$. Isto ocorreria porque os vícios - como a ganância, a vaidade, a luxúria, ou o egoísmo - seriam os grandes responsáveis pela preservação das virtudes. Alguns exemplos: sem a prostituição, seria praticamente impossível preservar a honestidade das moças de família. Do mesmo modo, é o luxo dos ricos que sustenta a horda que os serve. E qual seria o destino dos comerciantes se não fosse a vaidade feminina?

Portanto, se desaparecem os vícios, as conseqüências são catastróficas: “But $O h$ ye Gods! What Consternation, / vast and sudden was the Alteration!",188. A regeneração da sociedade faz, de fato, com que cada um dos pilares de sustentação e do sucesso da colméia comece a ruir. Sem vícios, desaparece uma infinidade de profissões que dependiam da opulência e da ostentação de alguns - nem mesmo os jardineiros encontram ocupação. O colapso se instala, e os resultados são fatais: "So few in the vast Hive remain". O poema demonstra, assim, que os vícios individuais só poderiam trazer benefícios à sociedade como um todo (daí a idéia de "private vices, public benefits"); uma sociedade inteiramente virtuosa estaria condenada à mediocridade, à miséria, ao desaparecimento. É esta a lição que o leitor tira dos versos finais: “T'enjoy the World's Conveniencies, / Be famed in War, yet live in Ease / Without great Vices, is a vain / Eutopia seated in the brain /Fraud, Luxury, and Pride must live / We the benefits receive" ${ }^{\prime 189}$.

A fábula de Mandeville abriu caminhos interpretativos em diferentes domínios do conhecimento. No campo da política, a aproximação com Hobbes não tardou a ocorrer. A diferença entre as duas visadas é, no entanto, radical: enquanto para o autor de Leviatã o contrato em torno do poder soberano é elemento-chave na estrutura social - é o que

\footnotetext{
${ }^{187}$ [Apesar de cada parte ser cheia de vícios, / o conjunto era um paraíso; / lisonjeados na paz, e temidos na guerra / eles eram estimados por estrangeiros, / e pródigos em sua riqueza e vida, / eram o equilíbrio de todas as outras colméias]. In: http://andromeda.rutgers.edu/, acessado dia 20/06/2006.

188 [Mas oh meu Deus! Que consternação, / vasta e repentina foi a alteração!]. In: http://andromeda.rutgers.edu/, acessado dia 20/06/2006.

${ }^{189}$ [para aproveitar das conveniências do mundo, / ser famoso na guerra, e ainda assim viver tranquilamente / sem muitos vícios, é uma vã / utopia dentro da cabeça. / Fraude, luxo e orgulho devem viver; / nós, os benefícios receber]. In: http://andromeda.rutgers.edu/, acessado dia 20/06/2006.
} 
garantiria um termo ao conflito latente entre os homens -, Mandeville propõe um laisser faire. A prática dos vícios, por si mesma, já funcionaria como reguladora da sociedade, sem que fosse necessário nenhum tipo de acordo ou contrato.

Na perspectiva da Fábula das Abelhas, qualquer tipo de intervenção do Estado poderia, inclusive, conduzir à falência da organização social. Como assinala Comparato, enquanto Hobbes analisa a vida social em termos voluntaristas, Mandeville (e um pouco mais tarde, Adam Smith) a observa como a "expressão da natureza humana". Ao invés de regulada pelo poder absoluto de um soberano, a sociedade funciona à maravilha guiada simplesmente pela tal "mão invisível", fonte do verdadeiro progresso: o mercado ${ }^{190}$.

Sob o ponto de vista do que se costuma chamar de filosofia moral, muitos dos contemporâneos de Mandeville compreenderam que o poema ia de encontro às idéias discutidas por outro ensaísta da época - o conde de Shaftesbury. Ao mesmo tempo austero aristocrata e ferrenho defensor das liberdades civis à la Whig, o conde parecia propor outra visão do sistema social. Contra a pequenez dos burgueses do mundo tal qual o pensara Mandeville, Shaftesbury vislumbrou uma ética da "natureza humana entendida prazerosamente como um fim em si mesma" ${ }^{\text {"191. }}$.

Ex-aluno de Locke, o autor de Characteristicks of Men, Manners, Opinions, and Times (1711) também parecia ser categoricamente contrário à visão do mundo de seu mestre. Para Shaftesbury, a "polidez”, característica inata ao ser humano, estava na base de uma filosofia moral que unia ética, estética e política. Assim, as leis morais não seriam subjetivas, nem decididas na dinâmica social, mas objetivas e absolutas. $\mathrm{O}$ corpo teria natural aversão ao que não é justo, bom e belo, e teria prazer em fazer o bem. Para uma convivência harmoniosa em sociedade, seria suficiente apenas seguirmos nossos instintos, afetos e impulsos prazerosos - qualquer comportamento não mediado por estes é considerado "não-moral". A verdade, o bem e a beleza caminham juntos: "amar $e$

\footnotetext{
${ }^{190}$ Ver COMPARATO, Fábio K. op. cit., p. 276.

${ }^{191}$ SHAFTESBURY, $3^{\text {rd }}$ Earl of. In: EAGLETON, Terry. A Ideologia da Estética. Rio de Janeiro: Jorge Zahar Editor, 1993. p. 32. O capítulo segundo, "A Lei do Coração: Shaftesbury, Hume, Burke" (pp. 29-54) está na base da discussão desenvolvida aqui.
} 
admirar a beleza é 'vantajoso para o afeto social, e de grande auxílio à virtude, que não é outra coisa senão o amor à ordem e à beleza na sociedade ${ }^{\prime 192}$.

Portanto, enquanto Mandeville propunha que o vício era característica essencial do ser humano - funcionando assim, como "pendant" para a virtude na origem dos benefícios públicos -, o conde de Shaftesbury se posicionava no extremo oposto, sugerindo a virtude "polida" como elemento constituinte do indivíduo e peça fundamental da organização social. É interessante notar, deste modo, que, apesar da divergência que os coloca em oposição quase simétrica, tanto Shaftesbury quanto Mandeville formalizam suas visões sobre a sociedade como uma totalidade passando ao largo da idéia do contrato.

Seja através de respostas a instintos benevolentes, seja através da satisfação constante dos vícios, os dois autores procuraram identificar, na sociedade inglesa de seu tempo, algo que era compartilhado por todos aqueles homens e que fazia, bem ou mal, com que o sistema funcionasse - sem a necessidade de leis civis ou de acordo explícito. Neste sentido, ambos procuraram imaginar seus contemporâneos ingleses como um grupo coeso em sua "natureza", e cujas leis de comportamento social eram geradas "internamente" pelos indivíduos. Este elemento de "coesão", comum a todos os homens, era simplesmente a lógica do mercado. Mandeville e Shaftesbury tornam-se, sob este ponto de vista, porta-vozes de um liberalismo ferrenho cujo embrião a realidade socioeconômica da Inglaterra vinha cultivando atentamente no terreno das relações.

Skinner acredita encontrar em David Simple - assim como em Volume the Last - a contraposição destes dois pontos de vista acerca do funcionamento do sistema social. Pode-se até concordar que Cynthia e David encarnam as teses dos dois autores, pelas posições assumidas na referida passagem do romance. Teríamos, assim, Cynthia como porta-voz do "cinismo mandevilliano", enquanto David permaneceria até o final acreditando em seus princípios shaftesburianos de bondade e virtude.

${ }^{192}$ EAGLETON, Terry. op. cit., p. 32. 
Porém, Sarah Fielding dá um passo adiante. Quando observamos a própria estrutura do romance - jogo entre estrutura episódica e dramática, depois afunilamento do foco narrativo na continuação de 1753 -, percebemos que a romancista expõe não somente a fragilidade dos dois "modelos" de sociedade (o mandevilliano e o shaftesburiano). O romance de Sarah F. não somente nega um modelo pelo outro, como expõe a sincronia onde se acreditava haver oposição. Revela, ainda, a impossibilidade de se vislumbrar qualquer tipo de totalidade sistêmica a partir destas perspectivas da organização social. Daí a dificuldade de dar um ritmo uníssono à narrativa. Os debates sugeridos por Mandeville e Shaftesbury são, portanto, claramente mediados antes de fazerem parte da narrativa de Sarah F., e um dos grandes indicadores de que esta mediação ocorre é a estrutura quebrada do romance, reproduzindo a movimentação no processo social.

A impossibilidade de se entrever totalidade na organização social significa, de um lado, que não estão mais tão claros os elementos que têm em comum os homens como espécie. O argumento da "natureza" - segundo o qual seríamos todos bons ou ruins de nascença - não se verifica na prática das relações, tornadas cada vez mais complexas pelas mudanças vertiginosas que ocorriam na Inglaterra naquele momento, tanto no âmbito da subsistência quanto na esfera da vida psíquica. $\mathrm{O}$ isolamento individual aparece como opção na luta pela sobrevivência e na busca por um sentido que não parece mais vir do grupo social. Aparece também, possivelmente, como o único ponto em comum entre os homens...

Como foi dito, este isolamento é reforçado pelo próprio processo de alienação que a vida urbana impunha a cada indivíduo. Além do mais, este processo não se restringiu às cidades, pois está diretamente relacionado com as condições específicas ao desenvolvimento fulminante do capitalismo na Inglaterra. A elite proprietária de terras também já era propriamente capitalista desde o século XVI, combinando, ao mesmo tempo, as precondições econômicas para o desenvolvimento do sistema a uma espécie de continuidade na esfera social - garantida, em grande parte, pela revolução de 1688 . 
De fato, a "Bloodless Revolution", como também chegou a ser chamada, pouco teve de gloriosa. Um acordo entre cavalheiros - burgueses e proprietários de terra mais "progressistas" - formalizou a estrutura política para o processo de intensa acumulação de capital que se seguiria à ascensão de William III. Segundo Christopher Hill, as relações feudais no campo já tinham sido abolidas oficialmente desde 1646, repercutindo o início do período de consolidação da concentração da propriedade de terras, além da substituição das relações agrárias tradicionais pelas leis do mercado. Em meados do século XVIII, este processo estava bastante adiantado:

In the favorable climate of the eighteenth century the capitalist development of agriculture was extended. 'The eighteenth-century gentry', in the words of $\mathrm{Mr}$ Thompson, 'made up a superbly successful and self-confident capitalist class. They combined, in their style of living, features of an agrarian and urban culture'. He refers to the 'profoundly capitalist style of thought of the class zestfully acquisitive and meticulous in attention to accountancy...(...) Smith's argument [in The Wealth of Nations] is derived, very largely, from agriculture'. ${ }^{193}$

A influência dos grandes proprietários sobre a política estatal, o aumento dos cercamentos, o desaparecimento progressivo da indústria doméstica foram fatores de peso para que as cidades fossem alimentadas com mão-de-obra barata - combustível para a Revolução Industrial em marcha -, enquanto no campo, a produção já se baseava no trabalho assalariado. Assim, a sociedade inglesa deste período se caracterizava por uma situação sui generis em relação aos outros países europeus, identificada por uma "união robusta e bem-fundada dos interesses agrários e mercantis, acompanhada de uma aproximação ideológica marcante entre a nova e a antiga elites sociais" $" 194$.

Mencionamos anteriormente a importância dos periódicos para esta aproximação. Ela se realizava na medida em que a auto-imagem idealizada das classes dominantes

\footnotetext{
${ }^{193}$ [No clima favorável do século XVIII o desenvolvimento capitalista da agricultura se ampliou. 'A pequena fidalguia do século XVIII', nas palavras de Thompson, 'formava uma classe capitalista bastante bem-sucedida e confiante. Eles combinavam, em seu estilo de vida, características de uma cultura agrária e de uma cultura urbana'. Ele se refere ao 'profundo estilo capitalista de pensar desta classe - ávida e meticulosa em relação à contabilidade... (...) O argumento de Smith [na Riqueza das Nações] é derivado, em grande parte, da agricultura.] HILL, Christopher. Reformation to Industrial Revolution. London: Penguin, 1992. p. 268.

${ }^{194}$ EAGLETON, Terry. op. cit., p. 32.
} 
inglesas deste período se definiria mais como uma "esfera pública" do que como uma classe "de estado" - e isso era, antes de tudo, conseqüência de relações sociais mais complexas que as mudanças econômicas vinham engendrando. Tratava-se de uma formação política com comportamento essencialmente burguês, esfera das "pessoas privadas reunidas em um público; elas reivindicam esta esfera pública regulamentada pela autoridade, mas diretamente contra a própria autoridade, a fim de discutir com ela as leis gerais da troca na esfera fundamentalmente privada, mas publicamente relevante, as leis do intercâmbio de mercadorias e do trabalho social" ${ }^{\text {"195. }}$.

As cidades inglesas epitomizavam estas mudanças na ordem social através dos pontos de encontro - como os jardins, os teatros ou as coffeehouses - e da publicação de jornais, periódicos, romances, numa grande variedade de textos dirigidos aos diferentes grupos urbanos. O poder das classes dominantes se propaga, assim, sorrateiramente, sob a forma de uma certa cultura da "civilidade", da "virtude", sendo naturalizado na "imediatez sensorial da vida empírica"196. Faz sentido o papel das diversas facetas da chamada "politeness" dentro deste universo.

Através da disseminação de comportamentos culturais que enfatizavam a sensibilidade individual, "a livre circulação de opiniões articuladas", "o status abstratamente uniforme de seus participantes"197, o bloco dirigente "naturalizava" seu poder. Dito de outro modo: diferenças à parte, aristocratas e burgueses encontravam numa pretensa ausência de rupturas na esfera das relações sociais a tranqüilidade para continuar lucrando muito e aumentar sua influência. Ao invés de se estabelecer pelo embate político, ou pela violência, ou ainda, ao invés de ser racionalizado - como ocorreu na Alemanha -, o poder das classes dominantes inglesas no século XVIII se apóia, em grande parte, neste esquema ideológico extremamente eficaz:

Se os valores morais que governam a vida social forem tão evidentes por si mesmos quanto o sabor dos pêssegos, muitas discussões acirradas podem ser

\footnotetext{
195 HABERMAS, Jürgen. Mudança Estrutural da Esfera Pública. Rio de Janeiro: Tempo Brasileiro, 2003. p. 42.

${ }^{196}$ EAGLETON, Terry. op. cit., p. 30.

${ }^{197}$ EAGLETON, Terry. op. cit., p. 30.
} 
evitadas. A sociedade como um todo, dada a sua condição fragmentada, é cada vez mais opaca à razão totalizadora; é difícil discernir qualquer projeto racional no cotidiano dos mercados. Mas podemos procurar no que parece o oposto de tudo isso, nos movimentos da sensibilidade individual, e encontrar lá a nossa mais segura articulação com um corpo comum. Em nossos instintos naturais de benevolência e compaixão somos levados, por alguma lei providencial, inacessível à razão, a essa harmonia uns com os outros. Os afetos do corpo não são meros impulsos subjetivos, mas a chave para um Estado bem organizado. ${ }^{198}$

Vale um breve retorno ao Conde de Shaftesbury, pois seus escritos sobre estética funcionam exemplarmente para o tipo de estratégia política que as elites inglesas suas contemporâneas adotaram. No Solilóquio, ou Conselho a um Autor ${ }^{199}$ (escrito por volta de 1704 e publicado junto com os outros textos de Shaftesbury, nas Characteristicks), o conde se propõe a aconselhar os escritores no que se refere às questões da arte poética e da composição. Segundo Lygia Caselato, o filósofo inglês pretende resolver a questão que parecia incomodar alguns defensores da cultura clássica - e, de modo mais abrangente, os partidários de atitudes sociais em continuidade com a tradição aristocrática: "como é possível retomar a antiguidade na modernidade, dada a diferença radical entre ambas as épocas?"200.

A proposta de Shaftesbury é a continuidade com a tradição cultural clássica através do diálogo - herança socrática por excelência. Em oposição à "filosofia especulativa típica dos modernos" ${ }^{201}$, o filósofo espera que se valorize a sabedoria moral cujo caminho nos é indicado por Sócrates e seus discípulos. O Solilóquio seria, assim, um convite ao diálogo interno, como "o diálogo de Sócrates com seu dáimon"202, na tentativa de se estabelecer uma filosofia da felicidade pela sociabilidade. O diálogo funciona aqui como veículo de ensinamentos a respeito da vida em sociedade e das práticas "naturais" que esta implica.

\footnotetext{
${ }^{198}$ EAGLETON, Terry. op. cit., p. 31.

199 Tradução de Lygia Caselato, Solilóquio, ou Conselho a um Autor. Tradução e Comentário. Dissertação de Mestrado. FFLCH - USP, Departamento de Filosofia (2001).

${ }^{200}$ CASELATO, Lygia. op. cit., p. 16.

${ }^{201}$ CASELATO, Lygia. op. cit., p. 45.

${ }^{202}$ CASELATO, Lygia. op. cit., p. 44.
} 
O interesse de Shaftesbury por Xenofonte - cujo testemunho mostra uma imagem de Sócrates interventor, "discutindo na agorá e nas ruas"203, com a intenção de educar os homens para servirem ao país e administrarem os negócios civis corretamente - denota, deste modo, a ênfase que espera dar ao diálogo como fonte de aprendizado para a vida em sociedade. Para o filósofo, é por esta via que a antiguidade poderia indicar os caminhos certos à modernidade.

Nesta perspectiva, podemos perceber a importância fundamental da esfera pública no comportamento do indivíduo. Lawrence Klein tem razão, portanto, quando aponta que Shaftesbury utilizava a noção de "polidez" de duas maneiras complementares, apesar de aparentemente divergentes. Em primeiro lugar, este termo aparece de modo tradicional, como o prolongamento de uma certa cultura de "gentlemen" aristocráticos que o conde não gostaria de ver perecer; por outro lado, sua utilização do termo é carregada de inovação, na medida em que pretende incluir esta "nova" categoria, o público. Através de uma estética ética e política que mistura o "antigo" e o "novo", Shaftesbury anuncia seu papel de grande "propagador" da naturalização do poder das elites ${ }^{204}$.

A "polidez" se instala, assim, através do "diálogo" - mesmo que seja escrito e publicado num periódico. Ao estimular o cultivo da virtude polida através da conversação como panacéia para as dificuldades no trato na esfera pública, o filósofo indica, na realidade, o caminho para a "neutralização" destes embates políticos sob o disfarce da "natureza humana" comum... Porém, no romance de Sara F., o que observamos é que as peripécias do herói pelos diferentes universos do mundo "polido", ao mesmo tempo em que recusam a lógica do vício, expõem o esvaziamento do discurso pronto que as regras de conversação propunham. Os encontros de David denunciam a alienação de todo o esquema da "polidez" através da tríade jogo-teatro-conversas de salão e indicam o profundo isolamento dos indivíduos.

\footnotetext{
203 Ver CHAUÍ, Marilena. Introdução à História da Filosofia. Volume 1: Dos Pré-Socráticos a Aristóteles. São Paulo: Companhia das Letras, 2004. p, 183. Vale lembrar aqui que Sarah Fielding traduziu, para o inglês, os Memoráveis de Xenofonte, edição publicada em 1762.

${ }^{204}$ Ver KLEIN, Lawrence E. op. cit. 21-22.
} 
Como tentativa - ou esperança - de romper com este isolamento, aparecem os capítulos "dramáticos", nos quais temos contato com discursos articulados que forçosamente têm significado mais "real" em função das equivalências - no sentido de Diderot - que sua organização estimula. A estrutura geral da primeira parte do romance expõe, assim, o alcance deste processo de interiorização - e de hegemonização - de regras sociais e, ao mesmo tempo, suas limitações na experiência do cotidiano.

Por este prisma, o discurso de Cynthia a que se refere Skinner em seu ensaio, se acusa semelhanças com as proposições de Mandeville, não pode ser tomado como recorte central no estudo do personagem, e muito menos como elemento que confere sentido global ao romance. O fato de que a romancista tenha trazido argumentos do debate mandevilliano para o interior de sua prosa vem confirmar, a nosso ver, o tipo de caracterização que pretendia desenvolver nos capítulos autobiográficos - uma caracterização que se volta para a estruturação articulada do pensamento dentro da lógica personalíssima do indivíduo, em contraste com a experiência anárquica - e falaciosa - do contato social. E se, na primeira etapa de suas aventuras, o herói de Sarah Fielding parece incorporar a visada shaftesburiana, esta característica serve fundamentalmente, como vimos, para que tal visada seja colocada à prova.

Porém, enquanto em David Simple os capítulos autobiográficos faziam vislumbrar a possibilidade de comunicação de fato entre alguns - ainda que poucos indivíduos, em Volume the Last a perspectiva é bastante mais negativa. Enquanto na primeira etapa da história de David o modo dramático permite que as moças sejam ouvidas pelo herói (e pelo leitor) com total parcialidade - ficamos quase sempre do lado delas -, na continuação de 1753 já não existe mais esta possibilidade. Observamos assim o "afunilamento" do foco narrativo; desaparecem os capítulos dramáticos. Resta um narrador que centraliza o recorte dos assuntos e a condução da narrativa. Trata-se de um narrador bastante mais pessimista do que o primeiro, de David Simple, além de ter uma relação especial com seu leitor.

No que se refere ao pessimismo, bastante comentado desde a crítica de Malcolm Kelsall, inúmeras são as ocasiões em que o narrador manifesta este sentimento. De modo 
bastante cabisbaixo, explica, por exemplo - no primeiro capítulo de Volume the Last que, ao reencontrar Mr. Orgueil, David considerava-o como um amigo, mas que a palavra não tinha mais o mesmo sentido que adquiriu no início de seus passeios londrinos:

I [narrador] would not be understood to mean, by the Word Friend, a Person answering the Idea of what David Simple, in the former part of his Life, made the object of his Pursuit. His Search in that respect was happily ended; (...) this Friendship with Mr. Orgueil was no more than what is called generally by that Name (...) $)^{205}$. (VL, 321-322)

A regra social, em David Simple, ainda implica significados compartilhados, mesmo que estes sejam colocados em questão pela ironia e pelos conflitos apontados nos capítulos autobiográficos. Na primeira "fase" do romance, a impossibilidade de se entrever um mundo em que valores são inteiramente compartilhados já está colocada, mas o recurso ao modo dramático ainda oferece o direito à dúvida. Em Volume the Last, a concentração do foco em um só narrador onipresente faz com que este ecoe de modo muito mais contundente a extrema convencionalização da linguagem nos meios "elegantes", a ausência de um vocabulário comum entre as pessoas, o vazio de conteúdo que isto implica.

Este comportamento do narrador é reforçado quando percebemos que ele projeta um outro tipo de leitor, indicando - em oposição ao narrador de David Simple - uma mudança na relação com o leitor. Parece que o "polite World" que parecia lhe servir de público talvez não corresponda mesmo à realidade:

But was I to attempt fully to describe the Happiness which subsisted in this Society, where Chearfulness and Good Humour were looked on as the Chief Ingredients for Conversation, I am sensible how very short I should fall of my intended Purpose. Those, therefore, of my Readers, who have a Relish for the same kind of Conversation, will, I doubt not, make use of their own Imaginations, in drawing the Picture of the life: but to those, who mistake bonmots, insulting Raillery, malicious Ridicule, and murtherous Slander for the Attic Salt of Society, I write not. Indeed, to such I cannot write, concerning David, and

\footnotetext{
${ }^{205}$ [Eu não quis dizer, com a palavra "amigo", uma pessoa atendendo à idéia que David Simple, na primeira parte de sua vida, tinha como objetivo. A este respeito, sua busca tinha terminado de maneira feliz; (...) esta amizade com Mr. Orgueil não era mais do que geralmente se costuma chamar assim (...).]
} 
his Company; as no Words are equal to the raising in such Minds, any true Image of the Pleasures of our happy Society: for to them, Cynthia's Spriteliness (wanting the Relish of biting Jokes and tart Repartees) would appear trifling Insipidity; and the cheerful Softness of the gentle Camilla, would, by such, be termed Dullness and Want of Sensibility ${ }^{206}$. (VL, 315-316)

O que o narrador descreve é praticamente um “anti-leitor”. Malicioso, difamador e mesmo mal intencionado, este outro leitor que o narrador parece conhecer tão bem é a ruptura social levada às últimas conseqüências dentro da estrutura do romance. $\mathrm{Na}$ reprodução da ausência de totalidade, até a relação de cumplicidade entre narrador e leitor se rompe - de modo bastante diferente das pequenas rupturas que um narrador "enxerido" (como o de Henry Fielding) insere no enredo. A hostilidade que em alguns momentos se instala entre o narrador de Sarah F. e seu leitor em Volume the Last não aparece, de fato, nas "armadilhas" do narrador de um romance como Tom Jones.

No que se refere à caracterização, já observamos como, de um lado, Cynthia e Camilla perdem a dimensão dramática da primeira parte do romance; por outro lado, os personagens “planos” presentes em David Simple ganham profundidade em função de estarem em menor número na segunda parte da história. Mas a grande diferença se dá num outro patamar. Tomemos como exemplo o personagem Mr. Orgueil, que aparece em ambas as fases da vida de David. Em David Simple, Mr. Orgueil é apresentado ao leitor no capítulo nono. Durante as caminhadas do protagonista pela cidade, este resolve procurar estadia em Covent Garden. Ali os dois personagens se encontram pela primeira vez:

\footnotetext{
${ }^{206}$ [Se eu tentasse descrever por inteiro a felicidade que permanecia neste grupo, no qual a alegria e o bom humor eram vistos como os principais ingredientes para a conversa, sei que terminaria muito distante do meu objetivo. Aqueles, portanto, entre os meus leitores, que têm apreço pelo mesmo tipo de conversa, irão, sem dúvida, usar suas imaginações para ter uma imagem daquela vida: mas para aqueles que interpretam mal bon-mots, que vêem insultos, ridicularizações maliciosas, e difamações como o máximo sal da sociedade, não escrevo. De fato, para tais pessoas não posso escrever, sobre David, e seus amigos; já que não há palavras que possam elevar, em tais mentes, qualquer imagem verdadeira dos prazeres de nossa pequena sociedade: para eles, a graciocidade de Cynthia (com o tempero de piadas cruéis e comentários maldosos) pareceria tola insipidez; e a suavidade alegre da doce Camilla seria, do mesmo modo, considerada enfado e falta de sensibilidade.]
} 
(...) he [David] met with a Gentleman, who accidentally lodg'd in the same House, whose conversation Mr. Simple was mightly charmed with (...). This Gentleman, whose Name was Orgueil, being of French Extraction, was equally pleased with Mr. Simple, and they spent their whole time together (...). He [David] had a great deal of good Acquaintance, that is, he conversed with all the People of Sense he could meet with, without any Considerations what their Fortunes were; for he did not rate Men at all by the Riches they possessed, but by their own Behavior ${ }^{207}$. (DS, 57)

Segundo a descrição do narrador, é a conversa de Orgueil que atrai David - e não seu dinheiro e sua conseqüente posição social -, mas a decepção do herói acaba afastando os dois. Orgueil reaparece somente no primeiro capítulo de Volume the Last, quando David e sua família se instalam na casa de Heddington. Orgueil e sua mulher enviam uma carta ao herói e sua família oferecendo-lhes uma visita. O narrador reapresenta o francês para o leitor que já o havia esquecido:

David was a little astonished at the message, and, indeed, not a little averse to the Thought of renewing an Acquaintance with a Man, of whose Principles he had so just an Abhorrence. Yet, on the other hand, when he reflected, that the only Account he had received of Mr. Orgueil came from Spatter, who never gave any one a good Character (...) he hoped Orgueil might not be so bad a Man as he had been represented. (...) Mr. Orgueil had been settled in that Village about a Year, having bought a large Estate, with a very fine House on it: for Mrs. Orgueil brought him a Fortune of above Thirty thousand Pounds ${ }^{208}$. (VL, 320)

A diferença de abordagem é bastante clara. Enquanto no primeiro encontro dos dois personagens o critério parece ser moral, quando se apresenta a David a oportunidade

\footnotetext{
207 [(..) ele [David] encontrou um senhor que por acaso estava hospedado na mesma hospedaria e cuja conversa muito encantou Sr. Simple (...). Este senhor, cujo nome era Orgueil, pois ele era de origem francesa, também se encantou com Sr. Simple, e eles passaram todo o tempo juntos (...). Ele [David] tinha um bom número de bons conhecidos, ou seja, ele conversava com todas as pessoas de bom senso que ele conseguia encontrar, sem quaisquer considerações sobre quais eram suas fortunas; pois ele não classificava as pessoas por suas riquezas, mas por seu comportamento.]

208 [David se espantou um pouco com a mensagem, e de fato teve um pouco de aversão ao pensar em retomar a amizade com um homem cujos princípios detestava tanto. Apesar disso, por outro lado, quando refletiu que o único relato que tinha recebido sobre Sr. Orgueil tinha vindo de Spatter, que nunca dizia de ninguém ter bom caráter (...) ele quis acreditar que Orgueil não fosse um homem tão mau. (...) Mr. Orgueil vivia naquela cidadezinha havia um ano, pois comprara uma grande propriedade com uma ótima casa: pois Sra. Orgueil the trouxe uma fortuna acima de trinta mil libras.]
} 
de dar uma nova chance ao antigo amigo, a reapresentação de Orgueil já inclui mais precisão sobre sua situação socioeconômica.

O mesmo ocorre, aliás, com outros personagens menores de Volume the Last. Mr. Ratcliff, "amigo" e conselheiro de David em Londres, é apresentado como um "Man of Fortune"; Mr. Nichols, o agiota que David encontra em Heddington, "Steward to most of the Men of Fashion in that County, and who lent out Money on Interest"209 (VL, 367368). Mesmo o fazendeiro Dunster - que não faz parte da gentry, não é gentleman, mas foi único que interveio para ajudar David - passa pelo crivo da avaliação socioeconômica do narrador: "Farmer Dunster and his Wife were plain and well-meaning People, and, although they rented a very large Farm, yet they did not affect to live above their Station" 210 (VL, 321).

Assim, em Volume the Last, as relações de David com Orgueil - assim como com a maioria dos personagens da segunda parte do romance - são definidas também pelo filtro do dinheiro. Em conseqüência destes câmbios, parece lógico que o papel de Orgueil nas duas etapas da história da David não seja o mesmo. Em David Simple, o "amigo" francês aparenta ter duas funções principais. Ele aparece como um dos "guias" que conduzem David pelas cenas da vida na cidade - com Orgueil, o protagonista de Sarah F. visita uma taverna para encontrar "People who were bred to genteel Professions" (segundo o narrador, o tipo de companhia favorito do francês) e também o teatro.

Orgueil serve, ainda, como "mote" para certas discussões morais que o narrador pretende lançar ao seu leitor. David e o amigo conversam sobre os comportamentos sociais que observam, nos quais estão colocados à prova sentimentos como a bondade e a compaixão. Enquanto David se choca com o que vê, Orgueil apresenta um ponto de vista bastante claro a respeito do assunto:

\footnotetext{
${ }^{209}$ [Administrador da maioria dos homens elegantes da região, e que emprestava dinheiro a juros.]

${ }^{210}$ [O Fazendeiro Dunster e sua mulher eram pessoas simples e bem-intencionadas, e, apesar de alugarem uma fazenda muito grande, não fingiam viver acima de suas possibilidades.]
} 
I look upon Compassion, Sir, to be a very great Weakness; I have no Superstition to fright me into my Duty, but I do what I think just by all the World; for the real Love of Rectitude is the Motive of all my Actions. If I could be moved by a Compassion in my Temper to relieve another, the Merit of it would be entirely lost, because it would be chiefly done to please myself: But when I do it for any one, what they have a Right to demand from me, by the Laws of Society and right Reason, then it becomes real Virtue, and sound Wisdom²11. (DS, 71)

O posicionamento de Orgueil assusta David, mas ainda assim o protagonista resolve pensar mais sobre o assunto, pois, como explica o narrador, ele não poderia recusar uma tese para a qual não tinha ainda argumentos contrários. A relação entre os dois personagens no romance de 1744 é muito mais marcada, assim, pela discussão moral. A vida cotidiana de David não é em nada afetada pelas idéias de Orgueil nem pelas atitudes que estas acarretam.

Em Volume the Last, Orgueil não aparece exatamente com este mesmo papel. Torna-se, logo de início, um personagem mais "esférico": tem endereço certo, casa, esposa com bom dote, filha; sua movimentação dentro do enredo não é exclusivamente "funcional"- com o único objetivo de satisfazer as "tarefas morais" do narrador. O personagem tem mais autonomia em relação a David. No entanto, o fato de Sr. Orgueil ter sido mais aprofundado não dilui o sentimento de radicalização do isolamento que a segunda parte do romance carrega. Ao contrário, este sentimento é reforçado.

Antes de tudo, Orgueil é um homem que não tem nenhuma participação na vida do grupo que o circunda. O narrador explica, logo depois da morte da filha de Cynthia e Valentine nas mãos de Sra. Orgueil, que o marido desta deveria ser desculpado pela tragédia: "He was generally in his Study, contemplating his Rule of Rectitude, and exulting the Beauties of Human Reason (...)" ${ }^{212}$ (VL, 353). As leis da sociedade e as leis

\footnotetext{
${ }^{211}$ [Eu acredito que a compaixão, senhor, seja uma grande fraqueza; não tenho superstições que me assustem para que eu cumpra o meu dever, mas faço o que acredito ser justo em todo o mundo; pois o verdadeiro amor à retidão é o motivo de todas as minhas ações. Se eu pudesse ser induzido por uma compaixão em meu temperamento a aliviar outra, o mérito se perderia, porque seria principalmente para agradar a mim mesmo: Mas quando faço para qualquer outra pessoa algo que eles têm direito de me pedir, pelas leis da sociedade e da razão, então se torna virtude de fato, e clara sabedoria].

${ }^{212}$ [Ele geralmente ficava em seu escritório, contemplando sua Regra de Retidão, e exultando-se com as belezas da razão humana].
} 
da razão, que definem o personagem e sua conduta, simplesmente o impedem de agir e o isolam, permanentemente, em seu gabinete. A diferença é que, em David Simple, não havia necessidade de que este personagem agisse. Esta não era de todo modo sua função no enredo.

Em Volume the Last, ao contrário, o narrador desculpa ou lamenta em diferentes ocasiões a falta de iniciativa e a alienação de Orgueil, indicando que sua ação seria necessária dentro da trama e lamentando um pouco sua imobilidade. Entende-se, portanto, que na segunda parte da história de David, Orgueil expõe a impossibilidade de se imaginar uma sociedade em que as relações fossem justas e verdadeiras segundo leis racionais estabelecidas de antemão. A chamada "regra de retidão", que o personagem não cansa de repetir, resumiria este conjunto de regras de conduta social e filosofia de vida que seriam respeitadas cegamente por Sr. Orgueil.

Aparece neste ponto uma diferença essencial entre David e seu "amigo", a qual o narrador pretende apontar no capítulo seis de Volume the Last:

Perhaps the essential Difference between Mr. Orgueil and David did not so much arise from their differing in Judgements, as from the Disagreement of their Inclinations; for whenever David thought of wordly Affairs, (...) his Childrens and his Camilla's Wants were present to his Mind; his Wishes were all centered in their Relief (...); whilst, on the contrary, Mr. Orgueil's Wishes were all centered in keeping to his Rule of Rectitude, in giving such Advice as might preserve and increase his Admiration of his own Wisdom, and still retain the Man he called his Friend in Slavery and Dependance ${ }^{213}$ (VL, 364).

A oposição não se estabelece entre as idéias mandevillianas do vício útil e a teoria da benevolência natural de Shaftesbury, já que é feita a referência a um elemento fundamental que parecia ausente do embate entre os dois autores: a idéia de um conjunto

\footnotetext{
${ }^{213}$ [Talvez a diferença essencial entre Sr. Orgueil e David não residisse tanto no fato de divergirem em julgamento, mas de discordarem no que se refere a suas inclinações; pois sempre que David pensava em assuntos materiais, (...) as necessidades de seus filhos e de Camilla estavam presentes em sua mente; seus desejos estavam todos concentrados em aliviá-los (...); enquanto, ao contrário, os desejos de Sr. Orgueil estavam centralizados em manter sua Regra de Retidão, em dar conselhos que preservassem e aumentassem sua admiração por sua própria sabedoria, mas que deixassem o homem que ele chama de amigo na escravidão e dependência].
} 
de leis que (ao menos teoricamente) regulariam as relações em sociedade. Aqui, portanto, o conflito ocorre entre uma visada da sociedade que implica a existência de regras que guiariam as ações dos homens; e uma perspectiva plenamente individualista que, por convicção ou necessidade, não conta com estas regras e age segundo seus próprios princípios do que é correto, justo e bom para si e para os seus.

A dificuldade é que ambos os modelos - tanto o de Orgueil quanto o de David não parecem funcionar a contento para que se crie um sentimento de totalidade dentro da esfera social. Basta lembrarmos da incapacidade que Sr. Orgueil demonstra de sair de seu gabinete para interagir com o mundo; e do triste fim reservado a David e à sua família. Se o vício não trazia real prosperidade; se os humores individuais inspiravam muitos sentimentos, mas poucos que se assemelhassem de fato à virtude e à benevolência; e se as leis da sociedade tampouco garantiam que as pessoas agissem pelo o bem alheio, o que restava?

Nada mais do que o isolamento. Dão igualmente notícia deste, como já vimos, o ritmo de Volume the Last - romance mais curto já que os problemas formalizados são mais urgentes -, e as mudanças de endereço de David. Na passagem de Londres para Lincolnshire e depois para Heddington (com um incêndio que acaba desalojando a família de uma vez por todas), o herói e seus amigos vão progressivamente afastando-se da grande cidade e fechando-se num núcleo social bastante reduzido. Neste núcleo restam alguns poucos sinais de que ainda existiria uma remota possibilidade de encontrar valores comuns com outros indivíduos - e comportamentos condizentes com estes valores. Talvez representem esse fio de confiança o fazendeiro Dusnter e sua mulher, assim como a família que significa para Cynthia a promessa de abrigo após a morte de David. 
Conclusão: contendo breves comentários e o fim desta análise 


\section{Conclusão}

"Il est bien évident que je ne fais point un roman, puisque je néglige ce qu'un romancier ne manquerait pas d'employer. Celui qui prendrait ce que j'écris pour la vérité, serait peut-être moins dans l'erreur que celui qui le prendrait pour une fable."

(Diderot, Jacques, Le Fataliste)

Volume the Last termina com o narrador deixando um convite para os leitores mais ousados:

I will now draw the Veil, and if any of my Readers chuse to drag David Simple from the Grave, to struggle again in this World, and to reflect, every day, on the Vanity of its utmost Enjoyments, they may use their own Imaginations, and fancy David Simple still bustling about on Earth. But I chuse to think he is escaped from the Possibility of falling into any future Afflictions, and that neither the Malice of his pretented Friends, nor the Sufferings of his real ones, can ever again rend and torment his honest Heart ${ }^{214}$. (VL, 432)

Como num efeito de espelhos, o leitor que chegou até a última linha de Volume the Last percebe que, guiado pela busca de David, acabou percorrendo com ele os mesmos caminhos pela cidade de Londres e pela alma humana. Assim como o herói havia sido conduzido pelas ruas por Orgueil e Spatter, o leitor também foi guiado pelo narrador numa viagem semelhante. Da mesma maneira que David se aproximou de Cynthia, Camilla e Isabelle, tremendo diante das histórias pessoais de cada uma delas e

\footnotetext{
${ }^{214}$ [Eu agora vou descer o véu, e se algum dos meus leitores escolher tirar David Simple do túmulo, para batalhar novamente neste mundo, e para refletir, todos os dias, sobre a vaidade de seus maiores divertimentos, podem usar suas próprias imaginações, e imaginar David Simple mexendo-se ainda aí sobre a terra. Mas eu escolho pensar que ele tenha escapado da possibilidade de cair em novas aflições, e que nem a malícia de seus pretensos amigos, nem o sofrimento dos verdadeiros, pode nunca mais despedaçar e atormentar seu honesto coração].
} 
passeando, através daquelas vozes, por cenários diversos, o leitor tornou-se igualmente íntimo das mulheres, tendo aprendido com elas tanto quanto aprendeu David.

Sabemos que, na última parte da história, o narrador assume inteiramente o papel de guia. O aprendizado ainda é mais árduo para um leitor que duvida se pode contar com a boa vontade deste narrador. A viagem se torna mais difícil, bem menos leve do que na primeira etapa. Os caminhos tomados não são mais as ruas de Londres, mas, no vaivém de David e sua família, as trilhas exíguas da batalha destes personagens pela sobrevivência em seu meio social.

Procuramos mostrar que esta viagem só poderia ter sido ciceroneada por um narrador e por personagens saídos da pena de Sarah Fielding. Ao tomar emprestadas as lentes de Henry Fielding e Samuel Richardson, a romancista percebeu que havia um ponto cego, um lugar de encontro e conflito o qual nenhum dos dois conseguira enxergar e fazer pulsar simultaneamente num mesmo romance. Neste lugar preciso se encontra o cruzamento dos abalos quase sísmicos que a sociedade inglesa atravessava neste período de quase dez anos - 1744 a 1753 -, e que são anunciados pelas tentativas e erros da autora de David Simple e Volume the Last no nível da estruturação do romance, do enredo, da caracterização, da organização do espaço.

As diferentes saídas formais encontradas por Sarah Fielding nas duas partes da narrativa de David podem indicar o quanto, num período bastante curto da história inglesa, as mudanças vertiginosas nos modos de organização social e nas experiências pessoais colocavam na ordem do dia a necessidade constante de acomodação e reavaliação. Se Henry Fielding e Samuel Richardson puderam formalizar questões de seu tempo em estruturas cuja coerência interna é inegável, talvez seja porque, apesar de estarem no olho do furacão, tinham vista privilegiada - ou convicções mais profundas que lhes obnubilavam a visão. Sarah Fielding, como se sabe, estava provavelmente assistindo a tudo do quarto dos fundos; titubeou na forma, mas acabou por nos fornecer uma visada inédita sobre os conflitos de seu momento histórico.

Sob este ponto de vista, o convite que o narrador faz ao leitor no fim de Volume the Last pode ser visto quase como um desafio - ou mesmo como um blefe. Quem de nós 
leitores teria ainda coragem de lançar novamente mundo afora o pobre David, se já sabemos, por suas próprias experiências, que nada encontrará? Quem teria a ousadia de retomar sua busca? No século XVIII, o romance como gênero ainda procura se equilibrar na fina corda desta busca. Na Inglaterra, isto significa em muitos casos a explicitação mediada da aceleração do desenvolvimento do sistema capitalista e suas conseqüências. As tentativas formais de diferentes romancistas do período de estabelecimento do gênero no universo inglês setecentista nos informam sobre este processo de maneira excepcionalmente criativa.

Mas o convite pode ser também visto como mote para pensarmos sobre o romance (e a literatura), de modo geral, também como expressão da busca pelo sentido sentido da experiência humana, mas também da experiência histórica, ou de como viemos parar onde estamos... E sob esta perspectiva, acatamos - leitores e crítica- o apelo do narrador, interpelando o incansável David para que, durante novas e longas viagens, sua surpresa diante dos homens seja sempre fonte de aprendizado sobre o passado e de munição para as mudanças que só tardam a vir. 
Referências Bibliográficas 


\section{Referências Bibliográficas}

\section{Da autora}

FIELDING, Sarah. The Adventures of David Simple: Containing an Account of his Travels thro' the Cities of London and Westminster, in the Search of a Real Friend (1744), Oxford: Oxford University Press, 1969.

. Familiar Letters Between the Characters of David Simple, and Some

Others... To which is added, A Vision (1747).

The Governess, or Little Female Academy (1749), edited by Jill E. Grey. Oxford: Oxford University Press, 1968.

. Remarks on Clarissa, Addressed to the Author (1749), ed. Peter Sabor. Augustan Reprint Society, nos. 231-32, Los Angeles: William Andrews Clark Memorial Library, 1985.

. The Adventures of David Simple: Volume the Last in Which his History is Concluded (1753), edited by Malcolm Kelsall. Oxford: Oxford University Press, 1969. The Cry: A New Dramatic Fable (with Jane Collier, 1754), reprinted Delmar, New York: Scholars Facsimiles and Reprints, 1986.

. The Lives of Cleopatra and Octavia (1757), edited by Christopher D. Johnson, London and Toronto: Associated University Presses, 1994.

. The History of the Countess of Dellwyn (1759).

. The History of Ophelia, (1760).

.(trad.) Xenophon's Memoirs of Socrates, with the Defence of Socrates

Before his Judges: translated from the original Greek (Bath and London, 1762).

\section{Bibliografia geral.}

AUERBACH, Erich. Mimesis. The Representation of Reality in Western Literature, Princeton: Princeton University Press, 1991.

BAKHTIN, Mikhail. Questões de Literatura e Estética. A Teoria do Romance, São Paulo: Editora Hucitec/Annablume, 2002. 
BARCHAS, Janine. "Sarah Fielding's Dashing Style and Eighteenth-Century Print Culture", in: ELH, Volume 63, Number 3, Fall 1996. pp. 633-656.

BENJAMIN, Walter. "The Author as Producer", in: Understanding Brecht, London: Verso, 1992. pp. 85-103.

BERNSTEIN, John A. Shaftesbury, Rousseau, and Kant, London: Associated University Press, 1980.

BREE, Linda. Sarah Fielding, New York: Twayne Publishers, 1996.

BRUGÈRE, Fabienne. Théorie de l'art et philosophie de la sociabilité selon Shaftesbury, Paris : Editions Champion, 1999.

CANDIDO, Antonio. Literatura e Sociedade. Estudos de Teoria e História Literária, São Paulo: T.A.Queiroz Editor, 2000.

Formação da Literatura Brasileira. Momentos Decisivos. $1^{\circ}$ volume (1750-1836), São Paulo: Livraria Martins Editora, 1964.

A Educação pela Noite e Outros Ensaios, São Paulo: Editora

Ática, 2000.

O Discurso e a Cidade, São Paulo/Rio de Janeiro: Livraria Duas

Cidades/Ouro sobre Azul, 2004. , ROSENFELD, Anatol, PRADO, Décio de Almeida, SALLES GOMES, Paulo Emílio. A Personagem de Fiç̧ão. São Paulo: Perspectiva, 1995.

CARPEAUX, Otto Maria. História da Literatura Ocidental, Volume III. Rio de Janeiro: Edições O Cruzeiro, 1961.

CASELATO, Lygia. Solilóquio, ou Conselho a um Autor, de Anthony Ashley Cooper, Terceiro Conde de Shaftesbury (tradução e comentário). Dissertação de Mestrado apresentada ao Departamento de Filosofia da Faculdade de Filosofia, Letras e Ciências Humanas da Universidade de São Paulo, outubro/2001.

CASSIRER, Ernst. A Filosofia do Iluminismo. Campinas: Editora da Unicamp, 1992. . The Platonic Renaissance in England. London: Nelson, 1953.

CEVASCO, Maria Elisa. Para Ler Raymond Williams, São Paulo: Paz e Terra, 2001. CHAPPELL, Vere (ed.). The Cambridge Companion to Locke. Cambridge: Cambridge University Press, 1995.

COMPARATO, Fábio Konder. Ética. São Paulo: Companhia das Letras, 2006. 
COULET, Henri. Le Roman jusqu'à la Révolution, Paris: Armand Colin, 1991.

COSTA, Iná Camargo. Sinta o Drama, Petrópolis, Editora Vozes, 1998.

DIDEROT, Denis. Oeuvres. BILLY, André (org). Paris: Gallimard, 1951. . Jacques, le fataliste. Paris: Librairie Générale Française, 1983.

DRABBLE, Margaret, STRINGER, Jenny. The Concise Oxford Companion to English

Literature. London: Oxford University Press, 1990.

EAGLETON, Mary (ed). Feminist Literary Theory: a Reader, Oxford: Basil Blackwell, 1991.

EAGLETON, Terry. Marxism and Literary Criticism, London: Routledge, 1997.

Literary Theory. An Introduction, Oxford: Blackwell

Publishers, 1992.

Ideologia. Uma Introdução, São Paulo: Boitempo Editorial/Fundação

Editora da Unesp, 1997.

. A Ideologia da Estética, Rio de Janeiro: Jorge Zahar, 1993.

. Walter Benjamin or Torwards Revolutionary Criticism, London:

Verson, 1992.

. The Rape of Clarissa, University of Minnesota Press, 1982.

FAVRE, Robert (org.). La Littérature Française. Histoire et Perspectives. Lyon: Presses Universitaires de Lyon, 1990.

FIELDING, Henry. Joseph Andrews and Shamela. Oxford: Oxford University Press, 1980.

GADEKEN, Sara. "Sarah Fielding and the Salic Law of Wit", in: Studies in English

Literature 1500-1900, Volume 42, Number 3, Summer 2002. pp. 541-557.

GUINSBurg, J. (org.), Diderot, Obras II - Estética, Poética e Contos. São Paulo: Perspectiva, 2000.

HABERMAS, Junger. Mudança Estrutural da Esfera Pública, Rio de Janeiro: Tempo Brasileiro, 2003.

HELLER, Deborah. "Bluestocking Salons and the Public Sphere", in: EighteenthCentury Life, Volume 22, Number 2, May 1998. pp. 59-82.

HILL, Christopher. O Mundo de Ponta Cabeça. Idéias Radicais durante a Revolução Inglesa de 1640, São Paulo: Companhia das Letras, 1987. 
. A Nation of Change and Novelty, London: Routledge, 1990.

. Society and Puritanism in Pre-Revolutionary England, Penguin

Books, 1984.

- Reformation to Industrial Revolution, The Penguin Economic

History of England, Volume 2 (1530-1780), London: Penguin Books, 1992.

. "Clarissa Harlowe and her Times". In: CARROLL, John. (ed.).

Samuel Richardson: A Collection of Critical Essays, New Jersey: Englewood Cliffs, 1969, pp. 102-123.

HOBSBAWM, Eric. A Era das Revoluções, São Paulo: Paz e Terra, 2001.

KELSALL, Malcolm. "Introduction", in: The Adventures of David Simple, Oxford: Oxford University Press, 1973. pp. ix-xvii.

KLEIN, Lawrence E. Shaftesbury and the culture of politeness. Moral discourse and cultural politics in early eighteenth-century England, Cambridge: Cambridge University Press, 1996.

MATOS, Franklyn de. A Cadeia Secreta: Diderot e o Romance Filosófico. São Paulo: Cosac \& Naify, 2004.

MAY, Georges. Le Dilemme du roman au XVIII siècle, Paris : PUF, 1963.

McKEON, Michael. The Origins of the English Novel (1600-1740), Baltimore: The Johns Hopkins Univesity Press, 1991.

MONTANDON, Alain. Le roman au XVIIIe siècle em Europe, Paris: Presses Universitaires de France, 1999.

MORNET, Daniel. Introduction. In: Rousseau, Jean-Jacques. La Nouvelle Héloïse, Paris : Hachette, 1925.

MUllan, John. "Sentimental Novels», in: The Cambridge Companion to the Eighteenth Century Novel, Cambridge: Cambridge University Press, 1996.

NUSSBAUM, Felicity and BROWN, Laura (eds.), The New Eighteenth Century: Theory, Politics, English Literature, New York and London, 1987.

PLUMB, J.H. England in the Eighteenth Century, London: Oxford University Press, 1973.

PORTER, Roy. English Society in the Eighteenth Century, London: Penguin, 1990. . The Creation of the Modern World. The Untold History of the 
British Enlightenment, London: W.W. Norton \& Company, 2000.

SCHWARZ, Roberto. Sequências Brasileiras, São Paulo: Companhia das Letras, 1999.

SHAKESPEARE, William. The Complete Works of William Shakespeare, New York: Gramercy Books, 1975.

Otelo, Porto Alegre: L\&PM Pocket, 1999. Tradução: Beatriz

Viégas-Faria.

SHATTOCK, Joanne. The Oxford Guide to British Women Writers, Oxford: Oxford University Press, 1993.

SKINNER, Gillian. “'The price of a tear': economic sense and sensibility in Sarah Fielding's David Simple”, in: Literature and History $3^{\text {rd }}$ series, vol. 1, no. 1, spring 1992, pp. 16-28.

SKINNER, Quentin. As Fundações do Pensamento Moderno, São Paulo: Companhia das Letras, 2003.

SPENCER, Jane. The Rise of the Woman Novelist. From Aphra Behn to Jane Austen. Oxford: Blackwell, 1986.

. "Women writers and the eighteenth century novel", in: The

Cambridge Companion to the Eighteenth Century Novel, Cambridge: Cambridge University Press, 1996.

SPENDER, Dale. Mothers of the Novel. London: Pandora, 1986.

SZONDI, Peter. Teoria do Drama Moderno, São Paulo: Cosac Naify, 2001. . Teoria do Drama Burguês, São Paulo: Cosac Naify, 2004.

TERRY, Richard. "David Simple and the Fallacy of Friendship", in: SEL, Volume 44, Number 3, Summer 2004. pp. 525-544.

TODD, Janet. Sensibility. An Introduction. London: Methuen, 1986.

(ed.). Dictionary of British Women Novelists, London: Routledge, 1991.

VASCONCELOS, Sandra Guardini Teixeira. Dez Lições sobre o Romance Inglês, São Paulo: Boitempo Editorial, 2002.

WATT, Ian. A Ascensão do Romance. Estudos sobre Defoe, Richardson e Fielding, São Paulo: Companhia das Letras, 1996.

WEBER, Max. A Ética Protestante e o Espírito do Capitalismo, São Paulo: Companhia das Letras, 2004. 
WIDDOWSON, Peter \& SELDEN, Raman. A Reader's Guide to Contemporary Literary Criticism, Hemel Hempstead: Haverster Wheatsheaf, 1993.

WILLIAMS, Raymond. Marxism and Literature, Oxford, Oxford University Press, 1977.

O Campo e a Cidade, São Paulo, Companhia das Letras, 1989. . Keywords, New York: Oxford University Press, 1985. Cultura, São Paulo: Paz e Terra, 1992.

WOMERSLEY, David (ed.). Augustan Critical Writing, London: Penguin Books, 1997.

SITES: http://www.cherster.ac.uk/english/

http://www.wwnorton.com/nael/18century/

http://www.gutenberg.org/

http://www.voltaire-integral.com/

http://gallica.bnf.fr/

$\underline{\text { http://andromeda.rutgers.edu/ }}$ 